\title{
AVALIAÇÃO DE PASTAGEM DE CAPIM-BRAQUIÁRIA EM DEGRADAÇÃO E SUA RECUPERAÇÃO COM SUPRIMENTO DE NITROGÊNIO E ENXOFRE
}

WALDSSIMILER TEIXEIRA DE MATTOS

Tese apresentada à Escola Superior de Agricultura

“Luiz de Queiroz", Universidade de São Paulo, para obtenção do título de Doutor em Agronomia, Área de Concentração: Solos e Nutrição de Plantas.

\author{
P I R A C I C A B A \\ Estado de São Paulo - Brasil \\ Maio - 2001
}




\title{
AVALIAÇÃO DE PASTAGEM DE CAPIM-BRAQUIÁRIA EM DEGRADAÇÃO E SUA RECUPERAÇÃO COM SUPRIMENTO DE NITROGÊNIO E ENXOFRE
}

\author{
WALDSSIMILER TEIXEIRA DE MATTOS
}

Engenheiro Agrônomo

Orientador: Prof. Dr. FRANCISCO ANTONIO MONTEIRO

Tese apresentada à Escola Superior de Agricultura "Luiz de Queiroz", Universidade de São Paulo, para obtenção do título de Doutor em Agronomia, Área de Concentração: Solos e Nutrição de Plantas.

\author{
P I R A C I C A B A \\ Estado de São Paulo - Brasil \\ Maio - 2001
}


Dados Internacionais de Catalogação na Publicação (CIP) DIVISÃO DE BIBLIOTECA E DOCUMENTAÇÃO - Campus “Luiz de Queiroz”/USP

\author{
Mattos, Waldssimiler Teixeira de \\ Avaliação de pastagem de capim-braquiária em degradação e sua recuperação \\ com suprimento de nitrogênio e enxofre / Waldssimiler Teixeira de Mattos. - - \\ Piracicaba, 2001 \\ 97 p. : il. \\ Tese (doutorado) - Escola Superior de Agricultura Luiz de Queiroz, 2001. \\ Bibliografia. \\ 1. Capim-braquiária 2. Degradação 3. Dosagem 4. Enxofre 5. Nitrogênio 6. \\ Pastagem 7. Recuperação I. Título
}

CDD 633.2 
Aos meus pais, Herbert e Maria Cecília, ao meu irmão Wlastermiler,

\section{OFEREÇO.}

A minha esposa ADRIANA pelo amor, apoio e incentivo, 


\section{AGRADECIMENTOS}

Ao Prof. Dr. Francisco Antonio Monteiro pela excelente orientação, apoio e principalmente pela amizade, confiança e ensinamentos oferecidos durante toda minha formação profissional, e pela importante contribuição no desenvolvimento deste trabalho.

Aos Professores Dr. Quirino Augusto de Camargo Carmello e Dr. Antonio Roque Dechen pela amizade, atenção, apoio e confiança.

A todos os demais professores do Curso de Solos e Nutrição de Plantas pelos conhecimentos transmitidos e amizade firmada.

Aos estagiários de Nutrição Mineral de Plantas pela colaboração nos trabalhos e amizade firmada.

Aos funcionários do laboratório de Nutrição Mineral de Plantas Edinéia C. S. Mandoni, Lúcia Helena S. P. Forti, Lurdes A. D. de González, Mirtes V. Sesso, Nivanda M. de Moura Ruiz e as secretárias Sueli M. A. C. Bovi e Nancy C. Amaral, pelo expressivo apoio.

Aos colegas de curso e amigos, especialmente Walcylene L. M. Pereira, Cirlene Aparecida Manarin e José Lavres Júnior pela ajuda, dedicação e amizade.

A minha esposa Adriana Libardi Martins de Mattos por toda paciência, amor e incentivo nestes anos todos.

Ao CNPq pelo apoio financeiro e institucional prestado para a realização deste trabalho.

Aos proprietários e funcionários da Fazenda Mundo Novo - MANAH pela imensa contribuição e colaboração para a realização deste trabalho. 


\section{SUMÁRIO}

Página

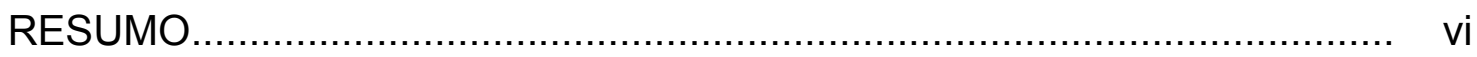

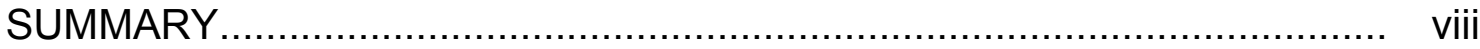

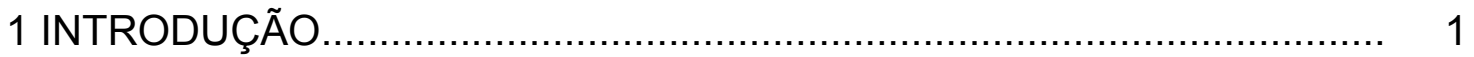

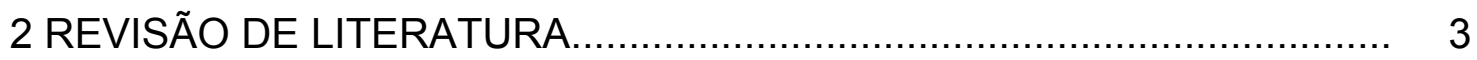

2.1 Recuperação de pastagens degradadas............................................ 3

2.2 Nitrogênio no capim-braquiária......................................................... 5

2.3 Enxofre no capim-braquiária............................................................... 8

2.4 Relação nitrogênio : enxofre ........................................................ 10

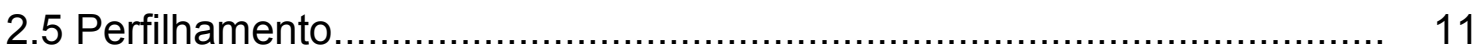

2.6 Estimativa do teor de clorofila........................................................ 13

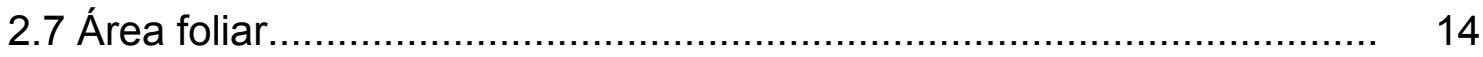

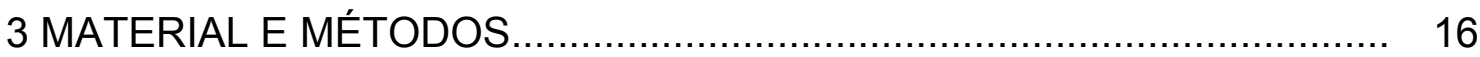

3.1 Primeira etapa experimental....................................................... 16

3.2 Segunda etapa experimental......................................................... 17

3.2.1 Localização e espécie forrageira.................................................. 17

3.2.2 Doses de nitrogênio e de enxofre e delineamento experimental.......... 17

3.2.3 Instalação e condução do experimento............................................. 17

3.2.4 Produção de matéria seca.......................................................... 20

3.2.5 Determinação do número de perfilhos, estimativa do teor de clorofila, avaliação da área foliar e determinações químicas............................. 21

3.2.6 Análises estatísticas................................................................... 22

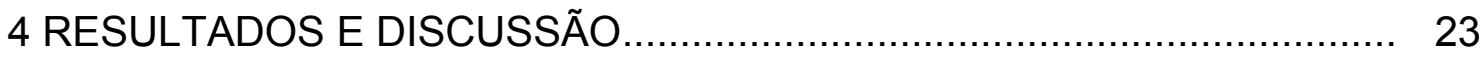

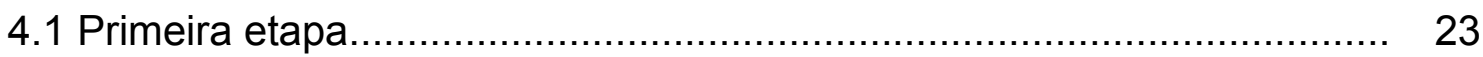

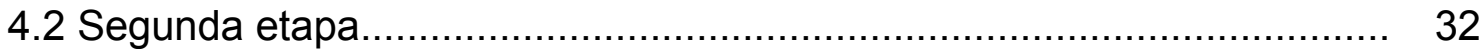

4.2.1 Experimento com forrageira proveniente de área não recentemente

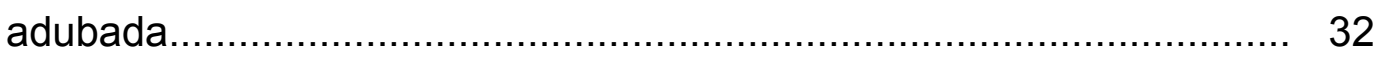

4.2.1.1 Produção de matéria seca da parte aérea...................................... 32 
4.2.1.2 Estimativa do teor de clorofila através do valor SPAD.................... 38

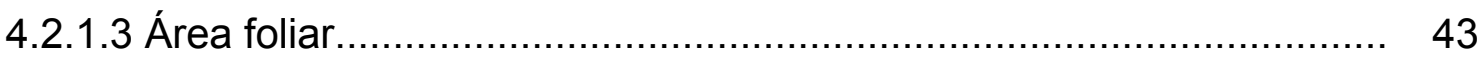

4.2.1.4 Número de perfilhos................................................................ 49

4.2.1.5 Concentração de nitrogênio e de enxofre nas lâminas de folhas recém-expandidas.............................................................. 53

4.2.2 Experimento com forrageira proveniente de área recentemente

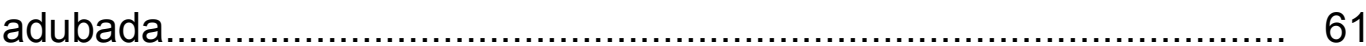

4.2.2.1 Produção de matéria seca da parte aérea..................................... 61

4.2.2.2 Estimativa do teor de clorofila através do valor SPAD .................... 67

4.2.2.3 Área foliar................................................................................. 71

4.2.2.4 Número de perfilhos................................................................ 76

4.2.2.5 Concentração de nitrogênio e de enxofre nas lâminas de folhas recém-expandidas.................................................................. 79

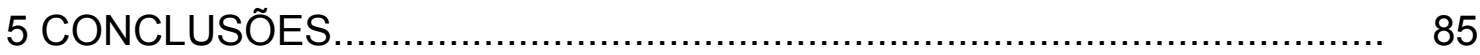

REFERÊNCIAS BIBLIOGRÁFICAS................................................... 87 


\title{
AVALIAÇÃO DE PASTAGEM DE CAPIM-BRAQUIÁRIA EM DEGRADAÇÃO E SUA RECUPERAÇÃO COM SUPRIMENTO DE NITROGÊNIO E ENXOFRE
}

\author{
Autor: WALDSSIMILER TEIXEIRA DE MATTOS \\ Orientador: Prof. Dr. FRANCISCO ANTONIO MONTEIRO
}

\section{RESUMO}

O presente trabalho foi desenvolvido com o objetivo de avaliar as condições de pastagens em degradação e a influência do nitrogênio e do enxofre na recuperação de Brachiaria decumbens Stapf. em estado de degradação. $O$ estudo foi realizado em duas etapas. A primeira consistiu no levantamento das condições nutricionais da forrageira em duas áreas contíguas, sendo uma não recentemente adubada e outra recentemente adubada. Foram coletadas folhas diagnósticas e raízes, bem como foram realizadas avaliações do teor de clorofila. Amostras de solo nas camadas de 0 a $10 \mathrm{~cm}$ e 10 a $20 \mathrm{~cm}$ também foram coletadas para a avaliação de fertilidade do solo. O solo amostrado na área recentemente adubada apresentou teores mais elevados de matéria orgânica, B, Cu, Fe e Zn em ambas camadas, que aquele da área não recentemente adubada. O capim na pastagem da área recentemente adubada apresentou concentrações mais elevadas de $\mathrm{N}, \mathrm{Cu}, \mathrm{Fe}$ e Zn que o capim da área não recentemente adubada. A segunda etapa, constituída de dois experimentos, foi conduzida em casa-de-vegetação com a utilização de 96 cilindros de solo contendo capim-braquiária, coletados nas áreas em estudo e colocados em vasos plásticos. Empregou-se um esquema 
fatorial $4 \times 3$ (doses de nitrogênio e de enxofre) perfazendo 12 combinações, as quais foram distribuídas segundo o delineamento experimental de blocos completos ao acaso, com quatro repetições, para cada experimento. Foram utilizadas quatro doses de nitrogênio $\left(0 ; 50 ; 100\right.$ e $200 \mathrm{mg} \mathrm{dm}^{-3}$ ) em combinação com três doses de enxofre $\left(0 ; 30\right.$ e $\left.60 \mathrm{mg} \mathrm{dm}^{-3}\right)$, com objetivo de avaliar os efeitos na produção de matéria seca da parte aérea, no perfilhamento, no teor de clorofila, na área foliar e na composição mineral da folha diagnóstica dessa forrageira. O primeiro corte das plantas ocorreu 40 dias após o corte de nivelamento, o segundo corte aos 40 dias após o primeiro corte e o terceiro corte aos 40 dias após o segundo corte.

Os resultados evidenciaram que a interação entre nitrogênio e enxofre foi significativa $(P<0,01)$ na produção de matéria seca da parte aérea da Brachiaria decumbens, no primeiro e no segundo crescimentos. Para o terceiro crescimento houve significância $(P<0,01)$ para as doses de nitrogênio para a forrageira procedente da área não recentemente adubada. Na produção de matéria seca da área recentemente adubada houve significância $(P<0,01)$ para as doses de nitrogênio e de enxofre no primeiro e no terceiro crescimentos. No segundo crescimento houve efeito significativo $(P<0,01)$ para doses de nitrogênio. No perfilhamento da forrageira houve significância $(P<0,01)$ para as doses de nitrogênio, nos crescimentos avaliados da forrageira, nos dois experimentos. As doses de nitrogênio tiveram significância $(P<0,01)$ na concentração de nitrogênio na folha diagnóstica dessa forrageira no primeiro crescimento, para ambos os experimentos. A interação entre doses de nitrogênio e de enxofre foi significativa $(P<0,01)$ para a concentração de nitrogênio na folha diagnóstica no segundo crescimento, nos dois experimentos e para a concentração de enxofre no terceiro crescimento, no experimento da área recentemente adubada.

Para a produtividade da Brachiaria decumbens na pastagem estudada sugere-se a aplicação conjunta de nitrogênio e enxofre. 


\title{
EVALUATION OF SIGNAL GRASS PASTURES UNDER DEGRADATION AND ITS RECOVERY THROUGH THE SUPPLY OF NITROGEN AND SULFUR
}

\author{
Author: WALDSSIMILER TEIXEIRA DE MATTOS \\ Adviser: Prof. Dr. FRANCISCO ANTONIO MONTEIRO
}

\section{SUMMARY}

The present work was conducted with the objective of evaluating pastures under degradation and the influences of nitrogen and sulfur supply for Brachiaria decumbens recovery. The study was accomplished in two stages. In the first one it was evaluated the nutritional conditions of this grass in two areas, one not recently fertilized and another recently fertilized. Diagnostic leaf laminae and roots were collected and chlorophyll concentration was determined. Soil samples, at 0 to $10 \mathrm{~cm}$ and 10 to $20 \mathrm{~cm}$ depth, were also collected for soil fertility evaluation. The soil sampled in the recently fertilized area showed higher concentrations of organic matter, B, Cu, Fe and $\mathrm{Zn}$ in both soil depth, than in the not recently fertilized area. The grass in the pasture of the recently fertilized area showed higher concentrations of $\mathrm{N}, \mathrm{Cu}, \mathrm{Fe}$ and $\mathrm{Zn}$ than in the not recently fertilized area. The second stage of this research was carried out in two experiments in a greenhouse for which 96 soil cores containing signal grass were collected in the studied pastures and put in plastic pots. A $4 \times 3$ factorial (nitrogen rates and sulfur rates) in a randomized complete block design, with four replications, was used in each experiment. Nitrogen rates were $0 ; 50 ; 100$ and $200 \mathrm{mg} \mathrm{dm}^{-3}$ whereas sulfur rates were $0 ; 30$ and $60 \mathrm{mg} \mathrm{dm}^{-3}$. Plant tops 
dry matter yield, plant tillering, chlorophyll concentration, leaf area and plant tissue mineral composition were evaluated. Plants were harvested three times at: 40 days after the leveling cut, 40 days after the first harvest and 40 days after the second harvest.

The results showed that the nitrogen $\mathrm{x}$ sulfur interaction was significant $(P<0.01)$ for the plant tops forage yield in the first and second harvests of both experiments. For the third harvest, nitrogen application had significant $(P<0.01)$ effect on forage yield in the grass coming from the area not fertilized in the field. Dry matter yield by the grass collected in the fertilized area was significantly $(P<0.01)$ affected by the nitrogen and sulfur rates in the first and third harvests. In the second harvest nitrogen rates had significant $(P<0.01)$ effects on forage yield. For the tiller number nitrogen rates were significant $(P<0.01)$, in the two experiments. Nitrogen rates significantly $(P<0.01)$ influenced nitrogen concentration in the diagnostic leaf laminae from the first harvest, in both experiments. Nitrogen $x$ sulfur interaction was significant $(P<0.01)$ for the nitrogen concentration in diagnostic leaf laminae in the second harvest in the two experiments, and for the sulfur concentration in diagnostic leaf laminae in the experiment with the grass originated in the not recently fertilized area.

The joint application of nitrogen and sulfur is suggested for the productivity of Brachiaria decumbens in the studied pastures. 


\section{INTRODUÇÃO}

O incremento da área de pastagens com forrageira do gênero Brachiaria no Brasil, nos 20 anos mais recentes, é bastante notório. Estima-se que atualmente as braquiárias ocupam aproximadamente 40 milhões de hectares de pastagens no Brasil Central. A tradição extrativista da maioria dos pecuaristas tem utilizado essas pastagens de forma que tem resultado na sua degradação.

Considerando a importância das pastagens de braquiária para a produção animal (particularmente para bovinos de corte) é possível prever, como conseqüência da utilização dessa forrageira, uma queda acentuada na produção pecuária do País, em função da degradação dessas áreas. Portanto, é necessário buscar rapidamente formas de recuperar essas pastagens degradadas e mesmo aquelas em vias de degradação.

$\mathrm{Na}$ degradação das pastagens, a produtividade das plantas e a composição botânica podem ser substancialmente alteradas ao longo do tempo, devido ao declínio da fertilidade do solo e ao manejo inadequado das plantas forrageiras.

A dificuldade na exploração de pastagens em solos de baixa fertilidade começa no estabelecimento da forrageira. Espécies mais exigentes em fertilidade do solo, como as dos gênero Pennisetum e Panicum, são mais difíceis de se estabelecerem nesses solos, enquanto que espécies como a Brachiaria decumbens Stapf. tem mostrado boa adaptação em solos de baixa fertilidade. Por outro lado, trabalhos tem mostrado algumas espécies dentro do 
gênero Brachiaria exigentes em nutrientes e, portanto, com necessidade de adubação.

O nitrogênio é o principal nutriente para a manutenção da produtividade das gramíneas forrageiras, sendo o principal constituinte das proteínas e de outros compostos orgânicos formadores da estrutura vegetal ou com atuação no metabolismo das plantas. Por sua vez o enxofre é requerido pelas plantas para a síntese de proteínas, pois faz parte da estrutura dos aminoácidos metionina e cisteína.

O estudo da Brachiaria decumbens Stapf. envolvendo o nitrogênio e o enxofre gerou informações que podem contribuir de forma positiva no estabelecimento, na recuperação e na produtividade da pastagem.

Os objetivos deste estudo foram avaliar aspectos produtivos, fisiológicos e nutricionais da Brachiaria decumbens em estado de degradação em pastagem estabelecida, e compará-los a pastagens da mesma espécie adubada com nitrogênio nos anos recentes; avaliar a forrageira quanto à produção de matéria seca da parte aérea, estimativa do teor de clorofila, área foliar, perfilhamento e composição química desta planta retirada de áreas não recentemente adubada e recentemente adubada, em termos da influência das doses de nitrogênio e de enxofre, com especial ênfase para a interação entre esses dois nutrientes. 


\section{REVISÃO DE LITERATURA}

\subsection{Recuperação de pastagens degradadas}

As pastagens no Brasil são, na sua maioria, constituídas exclusivamente de capins. Por isso, em razão do manejo inadequado e da ausência de reposição de nutrientes no solo, parte apreciável dessas pastagens encontra-se em processo de degradação ou já degradada.

A degradação das pastagens ocorre com a alteração do revestimento inicial do solo em termos de espécie forrageira. Assim, a forrageira de interesse vai sendo excluída da pastagem e acaba sendo substituída por outras plantas de baixo valor forrageiro (Soares Filho, 1993).

Soares Filho et al. (1992), trabalhando em um solo Podzólico VermelhoAmarelo distrófico, avaliaram os efeitos de algumas formas de recuperação de pastagens de Brachiaria decumbens Stapf. degradada, com 10 anos de uso. Os tratamentos utilizados foram testemunha, adubação com macro e micronutrientes + nitrogênio, gradagem e gradagem + adubação com macro e micronutrientes, mas sem nitrogênio. No tratamento onde aplicaram gradagem + adubação com macro e micronutrientes + nitrogênio foram adicionados 200 $\mathrm{kg}$ de sulfato de amônio, em duas épocas do ano. A gradagem exclusiva prejudicou a produção de matéria seca da parte aérea e das raízes, não recuperando a pastagem. A gradagem + adubação com macro e micronutrientes sem nitrogênio aumentou a produção de matéria seca, apenas 
no primeiro ano. Esse trabalho realçou a importância da adubação nitrogenada para a manutenção da produtividade das pastagens e seu efeito na recuperação de pastagens degradada.

Arruda et al. (1987) constataram que diversos tratamentos físicosmecânicos, com ou sem queima, com aração, aração + gradagem e cultivador não afetaram significativamente a recuperação da Brachiaria decumbens em solos de Tabuleiro no Sul da Bahia, mas que houve efeito marcante da aplicação de fertilizantes. Sem adubação, a produção de matéria seca foi de $844 \mathrm{~kg} \mathrm{ha}^{-1}$ e com a aplicação de fósforo de $22 \mathrm{~kg} \mathrm{ha}^{-1}$ a produção foi de 3386 $\mathrm{kg} \mathrm{ha}^{-1}$ e com a adubação completa de macronutrientes a produção de matéria seca foi de $4266 \mathrm{~kg} \mathrm{ha}^{-1}$.

Carvalho et al. (1990) obtiveram reduções na produção de matéria seca de Brachiaria decumbens Stapf. quando compararam a gradagem com a testemunha. A gradagem foi benéfica apenas quando acompanhada de calagem (1,5 Mg ha-1) e adubação (300 $\mathrm{kg} \mathrm{ha}^{-1}$ da fórmula 02-30-15 + $30 \mathrm{~kg} \mathrm{ha}^{-1}$ de FTE BR-12). Os autores obtiveram produção inferior (1,65 e 2,94 $\mathrm{Mg} \mathrm{ha}^{-1}$ ), de matéria seca aos 115 e 164 dias, respectivamente, com a inclusão dos fertilizantes à aração. Com gradagem apenas, as produções de matéria seca foram de 3,46 e $3,97 \mathrm{Mg}_{\text {ha }}{ }^{-1}$ para 115 e 164 dias, respectivamente. Os autores observaram, na primeira amostragem (aos 115 dias), a maior destruição de plantas provocada pela aração.

Segundo Soares Filho (1993) a baixa fertilidade do solo é um aspecto que deve ser destacado quando se pretende buscar a recuperação de pastagem. Todos os nutrientes das plantas podem ser limitantes numa dada condição de pastagens, mas tem sido freqüentes as limitações por fósforo, nitrogênio, enxofre e potássio, além de problemas de acidez do solo.

As pastagens cultivadas formadas exclusivamente com gramíneas necessitam de uma fonte de nitrogênio (química ou biológica) para reposição, segundo Werner (1986), com o objetivo de manter a produção de matéria seca, e consequentemente evitar a degradação do pasto. A deficiência de nitrogênio 
tem sido apontada como uma das principais causas da degradação das pastagens. Por outro lado, em se tratando de uma pastagem com forrageira do gênero Brachiaria o enxofre tem grande importância, pois essas plantas são exigentes em enxofre, principalmente, quando se aplicam doses elevadas de nitrogênio.

Tem-se verificado uma expansão da área de capins do gênero Brachiaria, que após dois ou três anos de utilização sob pastejo tem reduzido drasticamente sua produção de massa, afetando a produção de carne e leite. A possibilidade da braquiária consorciar-se com leguminosas de forma desejável é questionada por técnicos, já que essa gramínea é considerada agressiva, ocupando os espaços físicos do solo e não permitindo o estabelecimento e persistência de leguminosas na pastagem (Lourenço, 1993).

\subsection{Nitrogênio no capim-braquiária}

O nitrogênio não é um componente da rocha matriz, a qual é a grande fonte da maioria dos nutrientes minerais (Nascimento Jr., 1998). Segundo Raij (1991) apesar de ser um dos elementos mais difundidos na natureza, o nitrogênio praticamente não aparece nas rochas que dão origem aos solos, sendo o nitrogênio presente no ar (compondo $78 \%$ do mesmo), que é considerado a fonte primária deste elemento.

A fonte natural de nitrogênio no solo é a matéria orgânica, que não é absorvida diretamente pelas plantas, porém é necessário que ela se decomponha pela ação lenta e contínua dos microorganismos. Assim, conforme Boddey et al. (1993), é necessário verificar se essas contribuições de nitrogênio são suficientes para contrabalançar as perdas, principalmente derivadas das excreções dos animais, de forma a manter estável o teor de nitrogênio e de matéria orgânica no solo.

Monteiro \& Werner (1989) mencionaram que as perdas de nitrogênio por lixiviação e volatilização podem representar a principal forma de saída do 
elemento do sistema de uma pastagem exclusiva de gramínea, e vir a se constituir na principal causa de degradação das pastagens, caso não haja reposição desse nutriente por meio de fonte externa.

O nitrogênio é o principal nutriente para a manutenção da produtividade das gramíneas forrageiras, sendo o principal constituinte das proteínas que participam ativamente na síntese dos compostos orgânicos constituintes da estrutura vegetal, e portanto, responsável por características ligadas ao porte da planta tais como o tamanho das folhas, tamanho do colmo e aparecimento e desenvolvimento dos perfilhos (Werner, 1986).

O emprego de fertilizantes nitrogenados apresenta profundas mudanças nas características da pastagem, sendo o nitrogênio $o$ nutriente que proporciona efeitos mais consistentes, pois o fornecimento de nitrogênio, através de adubações, às pastagens tropicais possibilita um aumento no número, no peso e no tamanho de seus perfilhos associados a uma maior taxa de expansão foliar (Barbosa, 1998).

Sanzonowicz (1986) mencionou que em pastagens estabelecidas há cinco anos ou mais e que foram adubadas conforme recomendação do CPAC (Centro de Pesquisas Agropecuárias do Cerrado) o nitrogênio foi o nutriente que limitou a produtividade das pastagens de Brachiaria ruziziensis e Brachiaria decumbens.

Santos (1997), trabalhando com a braquiária decumbens, testou oito doses de nitrogênio $\left(0 ; 14 ; 42 ; 126 ; 210 ; 294 ; 378\right.$ e $\left.462 \mathrm{mg} \mathrm{L}^{-1}\right)$ e observou que as doses de nitrogênio proporcionaram aumentos na produção de matéria seca da parte aérea, das raízes e no número de perfilhos da forrageira. A concentração de nitrogênio foi mais baixa nos colmos+bainhas que nos demais componentes da parte aérea e o acúmulo do nutriente foi menor nas folhas nãoexpandidas e maior nos colmos+bainhas, nos dois crescimentos. As lâminas de folhas recém-expandidas mostraram-se as mais indicadas para a avaliação da nutrição em nitrogênio na braquiária. $O$ nível crítico de nitrogênio nessas 
lâminas foliares do capim-braquiária foi de 14,5 a $22 \mathrm{~g} \mathrm{~kg}^{-1}$ de matéria seca, o qual correspondeu a valor SPAD de 37 a 49.

Vicente-Chandler et al. (1972) encontraram respostas da Brachiaria ruziziensis a nitrogênio em dose até $400 \mathrm{~kg} \mathrm{ha}^{-1}$ para intervalos de corte de $30 \mathrm{e}$ 45 dias e até $200 \mathrm{~kg} \mathrm{ha}^{-1}$ para 60 e 90 dias. Segundo Vicente-Chandler (1973) as gramíneas tropicais podem responder a doses de nitrogênio de até $1800 \mathrm{~kg} / \mathrm{ha} / \mathrm{ano}$, sendo a magnitude dessas respostas variável conforme as espécies estudadas.

Harding \& Grof (1978), em estudo com a Brachiaria decumbens Stapf. adubada com nitrogênio onde a máxima dose foi de $1400 \mathrm{~kg} \mathrm{ha}^{-1}$, consideraram a dose de $365 \mathrm{~kg} \mathrm{ha}^{-1}$ por ano como ótimo, quanto a produção de matéria seca e o aproveitamento de nitrogênio.

Estudando acessos de Brachiaria estabelecidos em Latossolo VermelhoAmarelo, Alvim et al. (1990) constataram que todos responderam às doses de nitrogênio de até $150 \mathrm{~kg} \mathrm{ha}^{-1}$. Na dose de nitrogênio de $75 \mathrm{~kg} \mathrm{ha}^{-1}$, a produção de matéria seca dos acessos de Brachiaria decumbens e Brachiaria brizantha não mostraram diferenças. Entretanto, quando se omitiu o nitrogênio os acessos de Brachiaria decumbens foram mais produtivos que os demais.

Quando empregou a dose de nitrogênio de $437 \mathrm{mg} \mathrm{kg}^{-1}$ de solo, Hoffmann (1992) obteve a máxima produção da Brachiaria decumbens. Carvalho et al. (1991), ao submeterem a Brachiaria decumbens a doses de nitrogênio de $0,100,200$ e $400 \mathrm{~kg} \mathrm{ha}^{-1}$ por ano, observaram respostas significativas na produção de matéria seca da forrageira.

Fernandes et al. (1985) encontraram baixas concentrações de nitrogênio na parte aérea da Brachiaria decumbens, obtendo valores variando de 7,8 a 9,0 $\mathrm{g} \mathrm{kg}^{-1}$, em resposta às doses de nitrogênio de 0 e de $40 \mathrm{~kg} \mathrm{ha}^{-1}$, respectivamente. Salinas \& Gualdrón (1988) também obtiveram concentrações baixas de nitrogênio na parte aérea da Brachiaria decumbens, Brachiaria brizantha e Brachiaria humidicola, sendo que para a Brachiaria decumbens a concentração de nitrogênio diminuiu de $20,4 \mathrm{~g} \mathrm{~kg}^{-1}$ aos 28 dias para $11,0 \mathrm{~g} \mathrm{~kg}^{-1}$ 
aos 84 dias na estação chuvosa, enquanto na estação seca reduziu de $15,0 \mathrm{~g} \mathrm{~kg}^{-1}$ para $8,2 \mathrm{~g} \mathrm{~kg}^{-1}$, para o mesmo número de dias.

Em um Latossolo Vermelho-Amarelo álico, Carvalho et al. (1991) observaram que a concentração de nitrogênio na parte aérea da Brachiaria decumbens Stapf. aumentou linearmente com aplicação desse nutriente até $400 \mathrm{~kg} \mathrm{ha}^{-1}$. Esses autores também constataram que as concentrações de nitrogênio na parte aérea dessa forrageira foram consideradas baixas, com valores de 17,0 a $21,0 \mathrm{~g} \mathrm{~kg}^{-1}$, e quando não se aplicou o nitrogênio as concentrações desse nutriente variaram de 8,0 a $14,0 \mathrm{~g} \mathrm{~kg}^{-1}$.

\subsection{Enxofre no capim-braquiária}

O enxofre é componente dos aminoácidos cisteína e metionina, os quais podem conter cerca de $90 \%$ do total de enxofre na planta. É componente da acetil coenzima A e produtos secundários na planta e está envolvido na formação da clorofila e na síntese de vitaminas como tiamina e biotina (Malavolta et al., 1974). Também Vitti \& Novaes (1986) citaram que o enxofre faz parte de compostos que transmitem sabores e odores, os quais são importantes na aceitabilidade da forragem pelos animais.

Estudando a resposta de gramíneas forrageiras a quatro doses de enxofre $\left(0 ; 15 ; 30\right.$ e $\left.60 \mathrm{~kg} \mathrm{ha}^{-1}\right)$ nos solos Areias Quartzosas, Latossolo Vermelho-Escuro eutrófico fase cerradão e Latossolo Vermelho-Escuro distrófico fase cerrado, Casagrande \& Souza (1982), após três cortes, observaram que as forrageiras responderam significativamente até a dose de enxofre de $30 \mathrm{~kg} \mathrm{ha}^{-1}$, sendo Brachiaria decumbens e Melinis minutiflora cv. Cabelo-de-Negro as que mais responderam com aumento da produção de matéria seca.

Pereira (1986), estudando as respostas de várias gramíneas à adubação com enxofre, observou que a Brachiaria humidicola respondeu à dose de enxofre de somente $5 \mathrm{~kg} \mathrm{ha}^{-1}$, sendo menos exigente que a Brachiaria 
decumbens, a qual respondeu linearmente à aplicação de enxofre de até $20 \mathrm{~kg} \mathrm{ha}^{-1}$.

Ferrari Neto (1991), trabalhando em um Latossolo Vermelho-Escuro, verificou que, entre outros nutrientes, o enxofre apresentou níveis de deficiências severas para o desenvolvimento do capim-braquiária e do capimcolonião. Verificou, em condições de omissão de enxofre, que essas forrageiras apresentaram redução de 30 a $41 \%$ na produção de matéria seca da parte aérea, no total de dois cortes.

Segundo Hoffmann (1992) a Brachiaria decumbens alcançou o máximo rendimento da parte aérea com adição de enxofre de $76 \mathrm{mg} \mathrm{kg}^{-1}$ de solo. A aplicação de doses de enxofre até $160 \mathrm{mg} \mathrm{kg}^{-1}$ de solo resultou em aumento (de 0,6 a $3,4 \mathrm{~g} \mathrm{~kg}^{-1}$ ) na concentração de enxofre na parte aérea no primeiro e segundo cortes. Entretanto, quando incrementou as doses de nitrogênio, a concentração de enxofre diminuiu de 3,4 para $2,2 \mathrm{~g} \mathrm{~kg}^{-1}$ no primeiro corte e de 5,5 para $2,8 \mathrm{~g} \mathrm{~kg}^{-1}$ no segundo corte.

Ferrari Júnior et al. (1994), estudando a Brachiaria decumbens cv. Basilisk e a Brachiaria brizantha cv. Marandu cultivadas em um Latossolo Vermelho-Escuro, verificaram que a concentração de enxofre apresentou valor médio de $1,2 \mathrm{~g} \mathrm{~kg}^{-1}$ e não diferiu entre as gramíneas estudadas.

Respostas significativas na produção de matéria seca da braquiária decumbens cultivada em vasos com Latossolo Vermelho-Escuro, devido a aplicação de doses de enxofre, foram observadas por Faquin et al. (1995a). Os autores verificaram também que a matéria seca do segundo corte da Brachiaria brizantha apresentou baixa concentração de enxofre $\left(0,3 \mathrm{~g} \mathrm{~kg}^{-1}\right)$ no tratamento com omissão desse nutriente, quando comparada ao tratamento completo $\left(0,8 \mathrm{~g} \mathrm{~kg}^{-1}\right)$.

Faquin et al. (1995b) observaram, em estudo com a Brachiaria decumbens, que as máximas produções de matéria seca no primeiro e no segundo cortes foram obtidas nas doses de enxofre de 65 e $100 \mathrm{mg} \mathrm{kg}^{-1}$ de solo, respectivamente. Os autores verificaram que $90 \%$ destas produções, nos 
dois cortes, seriam atingidas com as doses de enxofre de 17 e $39 \mathrm{mg} \mathrm{kg}^{-1}$ de solo. Os maiores incrementos na produção da forrageira ocorreram com as doses mais baixas de enxofre.

Monteiro \& Ono (1995) constataram significativos incrementos na produção de matéria seca da parte aérea e das raízes da Brachiaria brizantha em conseqüência do suprimento de doses de enxofre em solução nutritiva.

Santos (1997), trabalhando com a braquiária decumbens, testou oito doses de enxofre $\left(0 ; 2 ; 4 ; 16 ; 32 ; 48 ; 64\right.$ e $\left.80 \mathrm{mg} \mathrm{L}^{-1}\right)$ e observou que as mesmas proporcionaram aumentos na produção de matéria seca da parte aérea e das raízes e no número de perfilhos no segundo crescimento da forrageira. As lâminas de folhas recém-maduras mostraram-se as mais indicadas para a avaliação da nutrição em enxofre na braquiária, e o nível crítico desse nutriente nessas lâminas foliares foi de 0,81 a $1,0 \mathrm{~g} \mathrm{~kg}^{-1}$ de matéria seca.

\subsection{Relação nitrogênio:enxofre}

O nitrogênio e o enxofre são constituintes da molécula dos aminoácidos e que em condições de deficiência interrompem a síntese de proteína.

Monteiro \& Carriel (1987) observaram que a aplicação de enxofre de 40 $\mathrm{kg} \mathrm{ha}^{-1}$ num solo Podzólico resultou numa relação $\mathrm{N}: S$ de 13,7:1 e numa concentração de aproximadamente $0,8 \mathrm{~g} \mathrm{~kg}^{-1}$ de enxofre no capim-colonião, por ocasião do segundo corte.

Werner \& Monteiro (1988) relataram que as pastagens com deficiência de nitrogênio respondem muito pouco ao enxofre. Por outro lado, em alta disponibilidade de nitrogênio a exigência por enxofre é maior, uma vez que este nutriente é importante no metabolismo do nitrogênio e na síntese de proteína.

Em estudo de casa-de-vegetação, Haddad (1983) verificou efeito quadrático de doses de enxofre, bem como interação positiva desse nutriente com o nitrogênio na produção de matéria seca de capim-colonião, e que 55 a 
$60 \mathrm{~kg} \mathrm{ha}^{-1}$ de enxofre foi $\mathrm{o}$ intervalo de dose que permitiu as máximas produções de matéria seca, para as doses de 100 e $200 \mathrm{~kg} \mathrm{ha}^{-1}$ de nitrogênio, respectivamente.

A relação entre as concentrações de nitrogênio e de enxofre (N:S) foi avaliada nos componentes do capim-braquiária, nos dois cortes, em função das doses de enxofre na solução, por Santos (1997). O autor observou que no primeiro corte os valores da relação $\mathrm{N}: \mathrm{S}$ nas folhas emergentes e nos colmos+bainhas apresentaram as mais baixas variações entre o menor e o maior valor dessa relação em função do incremento de enxofre na solução e as lâminas de folhas recém-maduras e as lâminas de folhas adultas apresentaram a mais alta variação (2,5 e 5,3 vezes) respectivamente nos valores dessa relação, considerando o menor e o maior valor observado.

Tamassia et al. (1999) estudaram três doses de nitrogênio (42; 210 e 378 $\left.\mathrm{mg} \mathrm{N} \mathrm{L}{ }^{-1}\right)$ e de enxofre $\left(3,2 ; 48\right.$ e $\left.80 \mathrm{mg} \mathrm{S} \mathrm{L}^{-1}\right)$ no estabelecimento do capimTanzânia e observaram que a combinação da dose $378 \mathrm{mg} \mathrm{N} \mathrm{L}^{-1}$ com $48 \mathrm{mg}$ $S \mathrm{~L}^{-1}$ resultou em maior produção de matéria seca no primeiro corte.

\subsection{Perfilhamento}

O perfilhamento é o resultado da formação e desenvolvimento de gemas axilares, em decorrência da interrupção da produção de auxinas. Cada novo perfilho apresenta três fases de desenvolvimento: formação de folhas, alongamento do caule e floração. $\mathrm{O}$ alongamento do caule resulta em elevação do meristema apical, expondo-o à destruição pelo corte mecânico ou pela boca do animal e representa uma fase de maior taxa de produção de matéria seca no desenvolvimento da planta (Gomide, 1986).

Espécies de gramíneas perenes contêm dois grupos de perfilhos: perfilhos basais que se originam da base da planta e possuem seu próprio sistema radicular, e perfilhos aéreos que surgem a partir de nós superiores dos 
colmos basais em florescimento e que não desenvolvem sistema radicular próprio (Loch, 1983).

Modelos de desenvolvimento de perfilhos foram detalhadamente examinados por Boornman (1971) e Loch (1985), em oito espécies de gramíneas tropicais, cultivadas sob condições de solo de alta fertilidade. Os estudos mostraram que o máximo perfilhamento ocorre durante a fase inicial do crescimento vegetativo. Os perfilhos aéreos, segundo Nabinger \& Medeiros (1995), são produzidos durante a fase reprodutiva, sendo estimulado por alta disponibilidade de água e de nitrogênio no solo.

Os perfilhos são formados a partir das gemas axilares dos entre-nós mais baixos da haste principal ou de um outro perfilho. Uma planta de gramínea é um conjunto de perfilhos provenientes de um perfilho primário ou da coroa (Skinner \& Nelson, 1994). Desta forma, os perfilhos de uma planta se desenvolvem de um mesmo zigoto e representam o mesmo genótipo. A arquitetura de uma planta individual de gramínea é, portanto, determinada pela morfologia e disposição espacial dos seus perfilhos.

A produção de perfilhos e de suas folhas é altamente sincronizada com a formação das folhas na haste principal, o que determina um padrão de surgimento de perfilhos altamente previsível.

Segundo Nabinger \& Medeiros (1997) o nitrogênio provoca efeitos positivos na taxa de aparecimento de perfilho. Contudo, elevada disponibilidade desse elemento pode ocasionar uma menor densidade de perfilhos na pastagem devido ao mais rápido desenvolvimento do índice de área foliar e ao aumento na mortalidade.

Werner (1986) enfatizou que o nitrogênio é fundamental no crescimento de gramíneas, tendo influência no tamanho das folhas, no colmo e no desenvolvimento dos perfilhos.

Hoffmann (1992), avaliando as respostas do capim Brachiaria decumbens a doses de nitrogênio até $500 \mathrm{mg} \mathrm{kg}^{-1}$ de solo, observou que o perfilhamento, no primeiro corte, seguiu a mesma tendência de resposta da 
matéria seca, embora as doses para o perfilhamento máximo, tenham sido superiores às necessárias para a produção de matéria seca.

Faquin et al. (1995b), em um experimento de casa-de-vegetação com Brachiaria decumbens cultivada em um Latossolo Vermelho-Escuro, verificaram respostas significativas às aplicações de enxofre para o perfilhamento da forrageira, sendo que na dose de $98 \mathrm{mg}$ de $\mathrm{S} \mathrm{kg}^{-1}$ de solo ocorreu o número máximo de perfilhos. Por outro lado, no perfilhamento do capim-colonião não houve influência desse nutriente.

Santos (1997) conduziu dois experimentos em casa-de-vegetação com solução nutritiva avaliando a diagnose nutricional de nitrogênio e de enxofre na espécie forrageira Brachiaria decumbens. Verificou que o incremento de nitrogênio na solução nutritiva proporcionou aumentos significativos no número de perfilhos em ambos os cortes. Porém, no estudo com doses de enxofre o número de perfilhos não sofreu influência no primeiro crescimento, mas foi incrementado no segundo crescimento nas doses de enxofre de 64 e $80 \mathrm{mg} \mathrm{L}^{-1}$ na solução nutritiva, em relação as demais doses utilizadas.

\subsection{Estimativa do teor de clorofila}

A determinação indireta do teor de clorofila de algumas forrageiras vem sendo feita através do aparelho Chlorophyll Meter SPAD-502 (Soil Plant Analysis Development), desenvolvido pela Minolta no Japão. Este clorofilômetro expressa os resultados em valores SPAD e vem sendo utilizado para estimar a concentração de nitrogênio na folha, pois o teor de clorofila e a concentração de nitrogênio apresentam correlação positiva. $O$ aparelho é de fácil manuseio, portátil e leve, além de permitir uma amostragem rápida e não destrutiva, pode ser utilizado em diversas condições ambientais a campo e predizer o aparecimento inicial da deficiência de nitrogênio (Minolta Camera Co., 1989).

Santos (1997), utilizando-se do clorofilômetro SPAD-502, para leituras de clorofila nas lâminas foliares do capim-braquiária, obteve alto coeficiente de 
correlação entre as leituras do aparelho e as doses de nitrogênio tanto no primeiro como no segundo crescimento da gramínea. Por outro lado para a correlação com as dose de enxofre apresentou baixos coeficientes de correlação entre a concentração de enxofre nas lâminas de folhas recémmaduras e o teor de clorofila. O nível crítico de nitrogênio no capim-braquiária esteve entre valores de SPAD de 37 a 49.

Colozza (1998), estudando o capim-Mombaça cultivado em Latossolo Vermelho-Amarelo em condições de casa-de-vegetação, obteve níveis críticos de nitrogênio entre 32,0 e 38,6 unidades SPAD. Manarin (2000), ao cultivar o mesmo capim em doses de nitrogênio, obteve valores entre 41 e 45 unidades SPAD para nível crítico de concentração de nitrogênio nas lâminas de folhas recém-expandidas.

\section{7 Área foliar}

O crescimento de um vegetal inicia-se com a germinação da semente, emergência da plântula e formação das primeiras folhas do perfilho principal. A continuação do processo de formação de folhas e o aparecimento de perfilhos primários e secundários caracterizam a fase linear de crescimento, de rápidos aumentos de peso, altura e área foliar. A última fase da curva sigmóide, que descreve o crescimento da planta, é alcançada quando a formação de novos tecidos é compensada pela senescência e morte de partes mais velhas (Taiz \& Zaiger, 1991).

A disponibilidade de nitrogênio é o fator dominante que controla os processos de crescimento e desenvolvimento da planta (Nabinger \& Medeiros, 1995). Esse elemento faz parte das proteínas, moléculas essenciais para o metabolismo dos seres vivos. Mas essas moléculas contêm em média $16 \%$ de nitrogênio e por isto a ação do nitrogênio só poderá resultar em aumento de biomassa agindo sobre a fixação do carbono. Esta ação se manifesta, de um 
lado, melhorando diretamente a eficiência da fotossíntese e, por outro lado, promovendo a redistribuição prioritária do carbono para a formação da parte aérea, que resulta em maior área fotossintetizante. Esse efeito é mais importante em relação ao primeiro e resulta do aumento da taxa de elongação de folhas por área e, em menor proporção, do ritmo de surgimento de folhas por área, menor senescência e maior número de perfilhos por área (Gastal \& Lemaire, 1988).

O efeito do nitrogênio na taxa de elongação foliar, segundo Gastal \& Nelson (1994), decorre do maior acúmulo deste nutriente na zona de alongamento da folha, mais precisamente na região de divisão celular. Os autores ainda verificaram alta correlação entre a quantidade de nitrogênio contido nessa região e a taxa de elongação foliar. Segundo Mazzanti \& Lemaire (1994) a deficiência de nitrogênio reduz ligeiramente a duração de vida das folhas, sendo que a taxa de senescência aumenta devido ao efeito do nitrogênio na taxa de aparecimento e no tamanho da folha.

Pinto et al. (1994), com o objetivo de estudar a taxa de expansão foliar de Panicum maximum Jacq. cv. Guiné e Setária anceps Stapf. Massey cv. Kazungula, no período entre os 17 e 38 dias após a emergência cultivadas com doses de nitrogênio, concluíram que o capim-guiné apresentou folhas maiores que o capim-setária. Manarim (2000) também verificou efeitos significativo de doses de nitrogênio na área foliar do capim-Mombaça. 


\section{MATERIAL E MÉTODOS}

\subsection{Primeira etapa experimental}

A primeira etapa da pesquisa foi desenvolvida em uma pastagem de Brachiaria decumbens Stapf. estabelecida em Neossolos Quartzarênicos utilizada com pastejo direto por bovinos de corte, que se encontra em estado de degradação e que tem parte da área adubada em anos recentes e está localizada no Município de Brotas, Fazenda Mundo Novo (pertencente à MANAH), no Estado de São Paulo.

Para a realização do estudo foram escolhidos dois piquetes das pastagens no quais foram localizados 48 pontos de amostragem, sendo que 24 pontos corresponderam a área não recentemente adubada (NRA), e os outros 24 à área recentemente adubada (RA) com uréia na dosagem de $100 \mathrm{~kg} \mathrm{ha}^{-1}$ no ano anterior a coleta das amostras. Em cada ponto foram retiradas amostras da parte aérea da forrageira, adotando a folha diagnóstica (duas lâminas de folhas recém-expandidas) recomendada por Santos (1997), bem como das raízes presentes na camada superficial do solo $(0-20 \mathrm{~cm})$. Essas partes das plantas foram analisadas no laboratório de análise de plantas conforme metodologia descrita por Sarruge \& Haag (1974). Paralelamente foram retiradas amostras de solo nas profundidades de $0-10 \mathrm{~cm}$ e $10-20 \mathrm{~cm}$, e essas amostras foram

processadas em laboratório de análise de solos segundo Raij \& Quaggio (1983). O teor de clorofila foi medido na posição do terço médio da lâmina foliar da segundo folha completamente expandida a partir do ápice de cada planta, através da leitura SPAD, utilizando-se de um Clorophyll Meter SPAD-502. 
Todos os resultados foram submetidos a análises estatísticas com o uso do pacote estatístico SAS (SAS Institute Corporation, 1989), empregando o teste t para amostras independentes, a fim de comparar os resultados nas áreas não recentemente adubada e recentemente adubada.

\subsection{Segunda etapa experimental}

\subsubsection{Localização e espécie forrageira}

Este estudo foi desenvolvido em casa-de-vegetação localizada no Departamento de Solos e Nutrição de Plantas, da Escola Superior de Agricultura "Luiz de Queiroz"-USP, em Piracicaba, no Estado de São Paulo. A espécie forrageira utilizada foi a Brachiaria decumbens Stapf., que foi cultivada no período de verão de 1999/2000.

\subsubsection{Doses de nitrogênio e de enxofre e delineamento experimental}

Foi utilizado um esquema fatorial $4 \times 3$, com uma combinação de quatro doses de nitrogênio $\left(0 ; 50 ; 100\right.$ e $\left.200 \mathrm{mg} \mathrm{dm}^{-3}\right)$ com três doses de enxofre (0; 30 e $60 \mathrm{mg} \mathrm{dm}^{-3}$ ), perfazendo um total de 12 combinações, as quais foram distribuídas segundo o delineamento experimental de blocos completos ao acaso, com quatro repetições.

\subsubsection{Instalação e condução do experimento}

Foram coletados 96 cilindros contendo a forrageira (parte aérea + raízes), sendo 48 cilindros retirados do pasto sem adubação e 48 do pasto que recebeu adubação nitrogenada nos anos recentes (Figuras 1 e 2). $O$ cilindro foi desenvolvido especialmente para tal finalidade, mede $15 \mathrm{~cm}$ de diâmetro e permite retirar material de 0 a $20 \mathrm{~cm}$ de profundidade. Esses cilindros com 


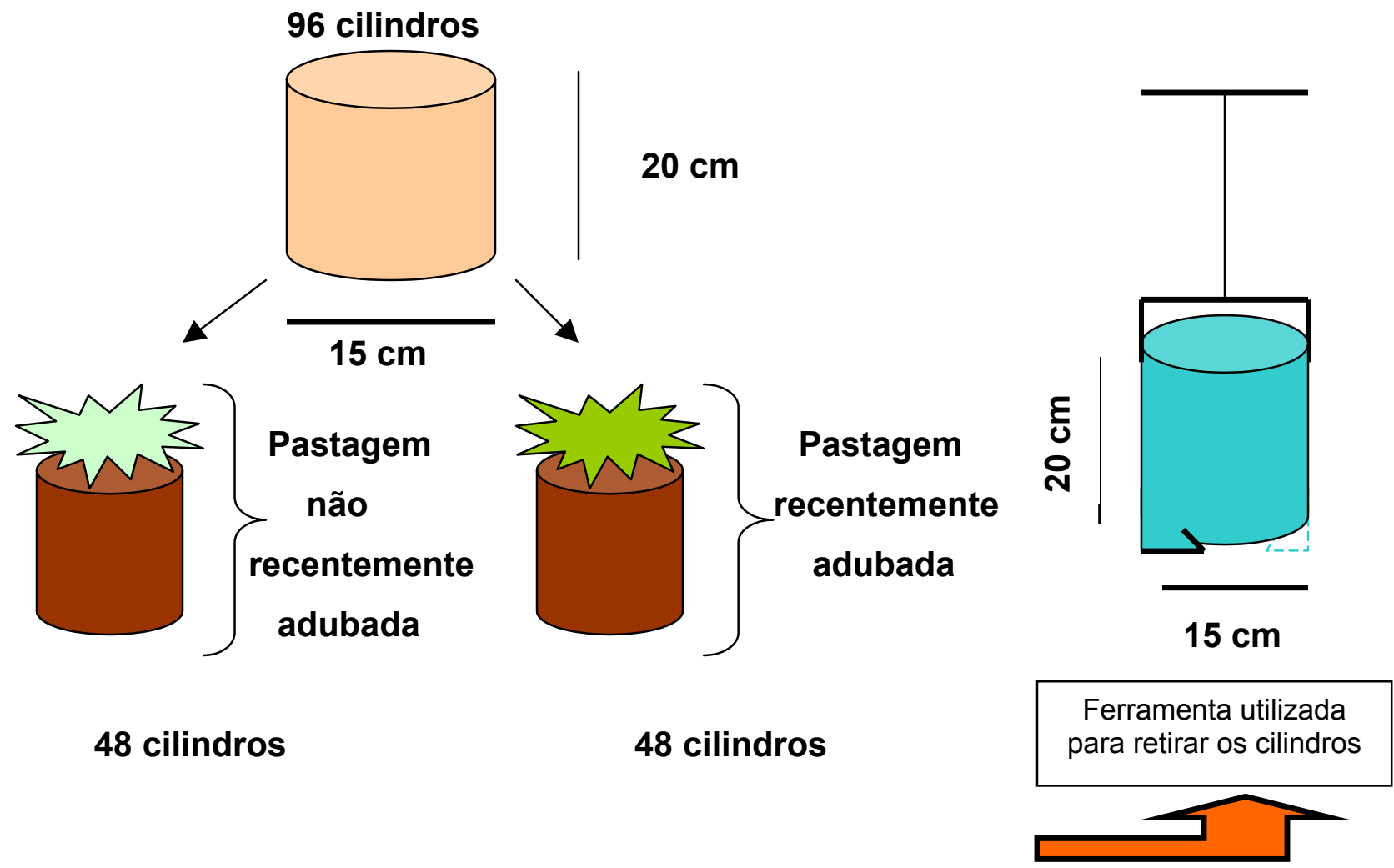

Figura 1 - Esquema dos cilindros de coleta da forrageira contendo parte aérea + raízes e solo.

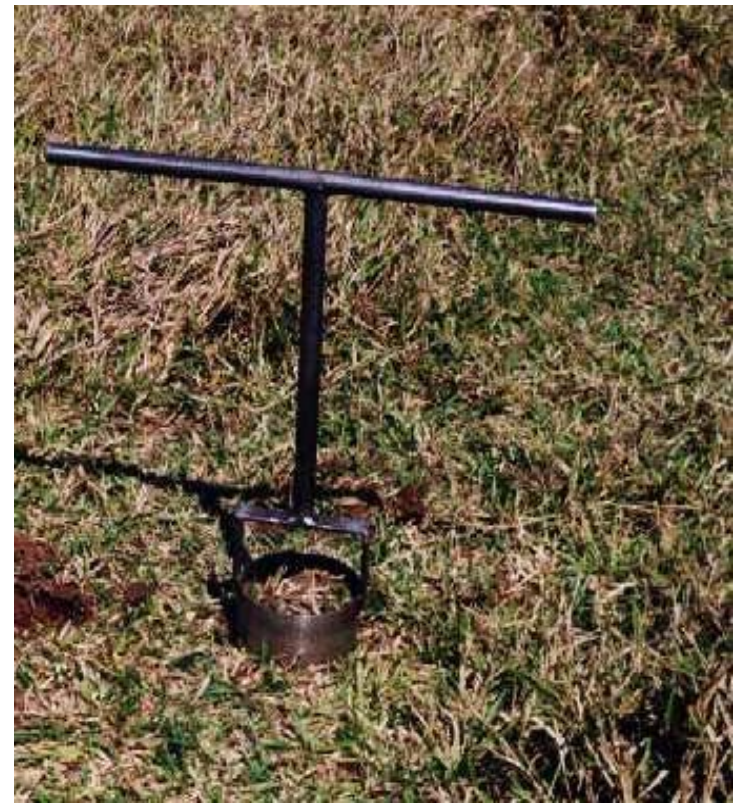

Figura 2 - Foto da coleta dos cilindros contendo a forrageira e solo. 
plantas+solo foram acondicionados em sacos plásticos e dentro de vasos plástico, sendo que em seguida foram levados para casa-de-vegetação e deles foram retiradas amostras de solo. Após um período de adaptação das plantas, realizou-se um corte de nivelamento e a distribuição do material de modo uniforme dentro de cada bloco experimental. Durante o período do experimento, a cada três dias os vasos eram remanejados dentro de cada bloco.

Os seguintes nutrientes foram aplicados em todos os vasos, na forma de solução diluída, no início do estudo, com o emprego dos reagentes analíticos com as respectivas quantidades: $\mathrm{H}_{3} \mathrm{BO}_{3}(5,0 \mathrm{mg} / \mathrm{vaso})$ correspondendo a dose de boro de $0,25 \mathrm{mg} \mathrm{kg}^{-1}$ de terra; $\mathrm{CuCl}_{2} .2 \mathrm{H}_{2} \mathrm{O}(9,4 \mathrm{mg} / \mathrm{vaso})$ correspondendo a dose de cobre de $1 \mathrm{mg} \mathrm{kg}^{-1}$ de terra; $\mathrm{ZnCl}_{2}$ (7,3 mg/vaso) correspondendo a dose de zinco de $1 \mathrm{mg} \mathrm{kg}^{-1}$ de terra e $\mathrm{Na}_{2} \mathrm{MoO}_{4} \cdot 2 \mathrm{H}_{2} \mathrm{O}$ (0,88 mg/vaso) correspondendo a dose de molibdênio de $0,1 \mathrm{mg} \mathrm{kg}^{-1}$ de terra.

A adubação com nitrogênio e enxofre foi efetuada em seguida ao corte de nivelamento, pela aplicação de uma solução preparada a partir dos reagentes analíticos nitrato de amônio $\left(\mathrm{NH}_{4} \mathrm{NO}_{3}\right)$ e sulfato de cálcio $\left(\mathrm{CaSO}_{4} \cdot 2 \mathrm{H}_{2} \mathrm{O}\right)$, respectivamente. As doses testadas foram: sem adubação com nitrogênio; com adubação nitrogenada de 50,100 e $200 \mathrm{mg} \mathrm{dm}^{-3}$ e sem adubação com enxofre; adubação com enxofre de 30 e $60 \mathrm{mg} \mathrm{dm}^{-3}$. A dose de cálcio presente na solução de sulfato de cálcio foi aplicada nos tratamentos com ausência de enxofre na forma de cloreto de cálcio.

Aos 40 dias após a adubação procedeu-se ao primeiro corte, a uma altura de $2 \mathrm{~cm}$ do colo das plantas, e a parte aérea então colhida foi separada em: a) folha emergente; b) lâminas de folhas recém-expandidas - lâminas das duas folhas superiores totalmente expandidas; c) lâminas de folhas maduras lâminas das demais folhas totalmente expandidas e d) colmos+bainhas colmos propriamente ditos mais as bainhas que foram mantidas a eles circundadas. As folhas foram consideradas totalmente expandidas quando apresentavam a lígula visível. 
Aos 40 dias após o primeiro corte realizou-se o segundo corte, a uma altura de $2 \mathrm{~cm}$ do colo das plantas, e a parte aérea foi separada segundo o mesmo critério do corte anterior. Após o segundo corte realizou-se uma nova adubação com as mesmas quantidades dos nutrientes utilizadas no início do experimento.

Aos 40 dias após o segundo corte procedeu-se o terceiro corte, na região do colo das plantas, e a parte aérea foi separada conforme os cortes anteriores, sendo que as raízes também foram separadas e lavadas. O material vegetal foi colocado para secar em estufa com circulação forçada de ar, à temperatura de $65{ }^{\circ} \mathrm{C}$, durante 72 horas, sendo então pesado, moído em moinho tipo Wiley e acondicionado em sacos de plásticos.

A análise dos atributos químicos do solo coletado da área não recentemente adubada, antes dos tratamentos mostrou: $\mathrm{P}=19 \mathrm{mg} \mathrm{dm}^{-3}$; M.O.= $25 \mathrm{~g} \mathrm{dm}^{-3} ; \mathrm{K}=0,8 \mathrm{mmol}_{\mathrm{c}} \mathrm{dm}^{-3} ; \mathrm{Ca}=5 \mathrm{mmol}_{\mathrm{c}} \mathrm{dm}^{-3} ; \mathrm{Mg}^{-}=3 \mathrm{mmol}_{\mathrm{c}} \mathrm{dm}^{-3} ; \mathrm{H}+\mathrm{Al}=$ $20 \mathrm{mmol}_{\mathrm{c}} \mathrm{dm}^{-3} ; \mathrm{pH}\left(\mathrm{CaCl}_{2}\right)=4,7 ; \mathrm{SB}=9,2 \mathrm{mmol}_{\mathrm{c}} \mathrm{dm}^{-3} ; \mathrm{CTC}=30,0 \mathrm{mmol}_{\mathrm{c}} \mathrm{dm}^{-3}$; $\mathrm{V}=31 \% ; \quad \mathrm{B}=0,16 \mathrm{mg} \mathrm{dm}^{-3} ; \quad \mathrm{Cu}=0,5 \mathrm{mg} \mathrm{dm}^{-3} ; \quad \mathrm{Fe}=61,2 \mathrm{mg} \mathrm{dm}^{-3} ; \mathrm{Mn}=$ $5,3 \mathrm{mg} \mathrm{dm}^{-3}$ e $\mathrm{Zn}=2,1 \mathrm{mg} \mathrm{dm}^{-3}$.

Para o solo coletado na área recentemente adubada a análise para os seguintes atributos químicos, revelou: $\mathrm{P}=19 \mathrm{mg} \mathrm{dm}^{-3}$; M.O. $=24 \mathrm{~g} \mathrm{dm}^{-3} ; \mathrm{K}=0,8$ $\mathrm{mmol}_{\mathrm{c}} \mathrm{dm}^{-3} ; \mathrm{Ca}=5 \mathrm{mmol}_{\mathrm{c}} \mathrm{dm}^{-3} ; \mathrm{Mg}=2,5 \mathrm{mmol}_{\mathrm{c}} \mathrm{dm}^{-3} ; \mathrm{H}+\mathrm{Al}=27 \mathrm{mmol}_{\mathrm{c}} \mathrm{dm}^{-3}$; $\mathrm{pH}\left(\mathrm{CaCl}_{2}\right)=4,4 ; \mathrm{SB}=8,3 \mathrm{mmol}_{\mathrm{c}} \mathrm{dm}^{-3} ; \mathrm{CTC}=35,5 \mathrm{mmol}_{\mathrm{c}} \mathrm{dm}^{-3} ; \mathrm{V}=23 \% ; \mathrm{B}$ $=0,29 \mathrm{mg} \mathrm{dm}^{-3} ; \mathrm{Cu}=1,8 \mathrm{mg} \mathrm{dm}^{-3} ; \mathrm{Fe}=83,3 \mathrm{mg} \mathrm{dm}^{-3} ; \mathrm{Mn}=3,3 \mathrm{mg} \mathrm{dm}^{-3}$ e $\mathrm{Zn}=$ $5,3 \mathrm{mg} \mathrm{dm}^{-3}$.

\subsubsection{Produção de matéria seca}

A produção de matéria seca foi determinada para a parte aérea através da soma do peso dos seus componentes secos (folhas emergentes, lâminas de folhas recém-expandidas, lâminas de folhas maduras e colmos+bainhas) e para as raízes das plantas, após a secagem em estufa. 


\subsubsection{Determinação do número de perfilhos, estimativa do teor de clorofila, avaliação da área foliar e determinações químicas}

O Chlorophyll Meter SPAD-502, (Soil-Plant Analysis Development Section, Minolta Camera Co., Osaka, Japan) foi utilizado para as medidas indiretas de clorofila em valor SPAD, em folhas intactas. Os espectros de absorção são determinados com base na quantidade de luz transmitida pela folha amostrada em dois comprimentos de onda, sendo nas áreas do vermelho aproximadamente em $650 \mathrm{~nm}$ e infravermelho em $940 \mathrm{~nm}$, onde os picos de absorção são máximo e mínimo, respectivamente. Nesta faixa, as leituras não são influenciadas pela presença de outros pigmentos. A luz transmitida é convertida em sinais elétricos, que são digitalizados e microprocessados para cálculo em valor SPAD da medida de clorofila (Minolta Câmera, 1989). As leituras do clorofilômetro foram realizadas antes do primeiro, segundo e terceiro cortes da forrageira, no terço médio da lâmina da segunda folha completamente expandida a partir do ápice de cada planta, conforme Santos (1997).

Ao final de cada crescimento, antes de realizar o corte das plantas realizou-se a contagem do número total de perfilhos nas plantas em cada unidade experimental.

Por ocasião do corte das plantas, as lâminas foliares tiveram sua área foliar medida em aparelho integrador de área foliar, marca LI-COR, modelo LI 3100. Após essa avaliação as lâminas foliares foram postas a secar em estufa.

A determinação da concentração de nitrogênio total e enxofre em cada componente da parte aérea e nas raízes foi executada conforme metodologia de Sarruge \& Haag (1974). A digestão sulfúrica foi utilizada para obtenção do extrato e a determinação do nitrogênio total envolveu a destilação em aparelho semi-micro Kjeldahl e titulação com ácido sulfúrico. Para a determinação do enxofre utilizou-se a digestão nítrico-perclórica e o método analítico empregado foi o indireto com cloreto de bário. 


\subsubsection{Análises estatísticas}

As análises estatísticas foram realizadas com o uso do pacote estatístico SAS (SAS Institute Corporation, 1989). Os resultados foram submetidos à análise de variância, considerando-se a significância para o teste $\mathrm{F}$ significativo a no mínimo de $95 \%$ de probabilidade $(\mathrm{P}<0,05)$.

Quando significativo o teste $F$ para a interação nitrogênio $x$ enxofre, procedeu-se ao desdobramento da mesma, buscando identificar-se em quais doses de nitrogênio ocorreram os efeitos devidos às doses de enxofre e em quais doses de enxofre eram significativos os efeitos devido às doses de nitrogênio. A partir daí efetuou-se o estudo das regressões e os efeitos que mostraram significância tiveram suas equações calculadas.

Nas situações em que não foi significativa $(P>0,05)$ a interação nitrogênio $x$ enxofre tratou-se de executar a análise de regressão para as doses do nutriente em que havia significância $(P<0,05)$ no efeito principal do mesmo, no teste $\mathrm{F}$.

A análise de regressão foi realizada para quantidade produzida de matéria seca, área foliar total, valor SPAD e concentrações dos macronutrientes, bem como o teste de comparação de médias (Tukey, ao nível de $99 \%$ de probabilidade) foi conduzido para o número de perfilhos. 


\section{RESULTADOS E DISCUSSÃO}

\subsection{Primeira etapa}

Os momentos estatísticos das variáveis analisadas, nas áreas não recentemente adubada (NRA) e recentemente adubada (RA) para o solo retirado da camada de 0 a $10 \mathrm{~cm}$, são apresentados na Tabela 1. Os níveis de significância para o teste de comparação de médias (teste t) entre NRA e RA são mostrados na Tabela 2.

Tabela 1. Momentos estatísticos dos atributos químicos do solo nas áreas não adubada recentemente (NRA) e adubada recentemente (RA) na camada de solo de 0 a $10 \mathrm{~cm}$.

\begin{tabular}{|c|c|c|c|c|c|c|c|c|}
\hline \multirow[t]{2}{*}{ Variáveis } & \multicolumn{4}{|c|}{ NRA } & \multicolumn{4}{|c|}{ RA } \\
\hline & $\begin{array}{l}\text { Média } \\
N=24\end{array}$ & $\begin{array}{l}\text { C.V. } \\
\%\end{array}$ & MIN. & $\overline{M A ́ X}$ & $\begin{array}{l}\text { Média } \\
\mathrm{N}=24\end{array}$ & $\begin{array}{c}\text { C.V. } \\
\%\end{array}$ & MIN. & MÁX. \\
\hline $\mathrm{pH}$ & 4,60 & 5,41 & 4,3 & 5,1 & 4,51 & 5,72 & 4,0 & 5,1 \\
\hline MO & 20,00 & 14,38 & 16,0 & 25,0 & 27,21 & 12,46 & 21,0 & 34,0 \\
\hline $\mathrm{P}$ & 11,29 & 45,98 & 5,0 & 26,0 & 16,12 & 35,63 & 4,0 & 39,0 \\
\hline K & 0,82 & 27,40 & 0,5 & 1,3 & 0,87 & 25,41 & 0,5 & 1,4 \\
\hline $\mathrm{Ca}$ & 6,92 & 30,58 & 4,0 & 13,0 & 6,29 & 19,81 & 3,0 & 13,0 \\
\hline $\mathrm{Mg}$ & 4,29 & 33,63 & 3,0 & 7,0 & 4,42 & 22,45 & 3,0 & 9,0 \\
\hline $\mathrm{H}^{+}+\mathrm{Al}^{+3}$ & 27,87 & 17,82 & 17,0 & 38,0 & 28,70 & 16,42 & 18,0 & 38,0 \\
\hline CTC & 39,74 & 11,70 & 30,0 & 45,9 & 40,44 & 9,52 & 27,4 & 48,7 \\
\hline SB & 11,78 & 27,56 & 6,2 & 21,9 & 11,70 & 22,11 & 6,9 & 23,2 \\
\hline 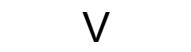 & 30,33 & 26,15 & 17,0 & 48,0 & 29,29 & 23,52 & 20,0 & 48,0 \\
\hline B & 0,21 & 32,22 & 0,09 & 0,40 & 0,28 & 30,15 & 0,18 & 0,40 \\
\hline $\mathrm{Cu}$ & 0,57 & 18,47 & 0,4 & 0,7 & 1,19 & 18,56 & 0,9 & 1,7 \\
\hline $\mathrm{Fe}$ & 66,05 & 7,39 & 46,3 & 77,7 & 78,05 & 6,54 & 66,1 & 91,8 \\
\hline $\mathrm{Mn}$ & 3,33 & 26,64 & 2,2 & 5,0 & 3,30 & 20,48 & 2,0 & 5,5 \\
\hline $\mathrm{Zn}$ & 1,33 & 28,47 & 0,7 & 2,4 & 3,47 & 27,89 & 1,8 & 4,9 \\
\hline
\end{tabular}

${ }^{*} \mathrm{pH}\left(\mathrm{CaCl}_{2}\right) ; \mathrm{MO}\left(\mathrm{g} \mathrm{dm}^{-3}\right) ; \mathrm{P}\left(\mathrm{mg} \mathrm{dm}^{-3}\right) ; \mathrm{K}, \mathrm{Ca}, \mathrm{Mg}, \mathrm{H}^{+}+\mathrm{Al}^{+3}, \mathrm{CTC}, \mathrm{SB}\left(\mathrm{mmol}_{\mathrm{c}} \mathrm{dm}^{-3}\right)$; $\mathrm{V}(\%) ; \mathrm{B}, \mathrm{Cu}, \mathrm{Fe}, \mathrm{Mn}, \mathrm{Zn}\left(\mathrm{mg} \mathrm{dm}^{-3}\right) ; \mathrm{C} . \mathrm{V} .(\%)$ 
Tabela 2. Níveis de significância associados aos testes de comparação de médias (teste t) entre NRA e RA para as variáveis analisadas na camada de solo de 0 a $10 \mathrm{~cm}$.

\begin{tabular}{crc}
\hline Variáveis & $\mathrm{t}$ & Prob>[t] \\
\hline $\mathrm{pH}$ & $-1,2783$ & 0,2075 \\
$\mathrm{MO}$ & 7,1956 & 0,0001 \\
$\mathrm{P}$ & 2,5294 & 0,0149 \\
$\mathrm{~K}$ & 0,6587 & 0,5134 \\
$\mathrm{Ca}$ & $-1,1044$ & 0,2752 \\
$\mathrm{Mg}$ & 0,3082 & 0,7593 \\
$\mathrm{H}^{+}+\mathrm{Al}^{+3}$ & 0,5398 & 0,5919 \\
$\mathrm{CTC}$ & 0,4448 & 0,6586 \\
$\mathrm{SB}$ & $-0,0880$ & 0,9303 \\
$\mathrm{~V}$ & $-0,5033$ & 0,6171 \\
$\mathrm{~B}$ & 3,0308 & 0,0040 \\
$\mathrm{Cu}$ & 12,0078 & 0,0001 \\
$\mathrm{Fe}$ & 5,7743 & 0,0001 \\
$\mathrm{Mn}$ & $-0,1035$ & 0,9180 \\
$\mathrm{Zn}$ & 10,8271 & 0,0001 \\
\hline
\end{tabular}

${ }^{*} \mathrm{pH}\left(\mathrm{CaCl}_{2}\right) ; \mathrm{MO}\left(\mathrm{g} \mathrm{dm}^{-3}\right) ; \mathrm{P}\left(\mathrm{mg} \mathrm{dm}^{-3}\right) ; \mathrm{K}, \mathrm{Ca}, \mathrm{Mg}, \mathrm{H}^{+}+\mathrm{Al}{ }^{+3}, \mathrm{CTC}, \mathrm{SB}\left(\mathrm{mmol}_{\mathrm{c}} \mathrm{dm}^{-}\right.$ $\left.{ }^{3}\right)$; V (\%); B, Cu, Fe, Mn e Zn (mg dm$\left.{ }^{-3}\right)$.

A análise estatística dos resultados indicou haver diferenças significativas $(P<0,05)$ para os valores do fósforo, matéria orgânica, boro, cobre, ferro e zinco nas áreas amostradas, na camada de solos de 0 a $10 \mathrm{~cm}$.

Os valores médios determinados, para as duas áreas amostradas, podem ser classificados como baixos nos casos de fósforo, potássio, cálcio, magnésio, CTC e V\%. A acidez do solo é considerada alta, de acordo com dados apresentados por Raij et al. (1996) enquanto os teores de matéria orgânica são considerados baixos, de acordo com Siqueira et al. (1987).

Para a camada de 10 a $20 \mathrm{~cm}$ de profundidade os momentos estatísticos das variáveis analisadas, nas áreas não recentemente adubada (NRA) e recentemente adubada (RA), são apresentados na Tabela 3. O nível de significância para o teste de comparação de médias (teste t) entre NRA e RA é mostrado na Tabela 4. 
Tabela 3. Momentos estatísticos dos atributos químicos do solo nas áreas não adubada (NRA) recentemente e adubada recentemente (RA) na camada de solo de 10 a $20 \mathrm{~cm}$.

\begin{tabular}{|c|c|c|c|c|c|c|c|c|}
\hline \multirow[t]{2}{*}{ Variáveis } & \multicolumn{4}{|c|}{ NRA } & \multicolumn{4}{|c|}{ RA } \\
\hline & $\begin{array}{l}\text { Média } \\
N=24\end{array}$ & $\begin{array}{c}\text { C.V. } \\
\%\end{array}$ & MIN. & $\overline{\text { MÁX. }}$ & $\begin{array}{l}\text { Média } \\
\mathrm{N}=24\end{array}$ & $\begin{array}{c}\text { C.V. } \\
\%\end{array}$ & MIN. & MÁX. \\
\hline $\mathrm{pH}$ & 5,45 & 20,84 & 3,7 & 8,5 & 4,17 & 15,49 & 3,9 & 4,5 \\
\hline MO & 15,96 & 17,63 & 10,0 & 21,0 & 18,87 & 14,77 & 11,0 & 27,0 \\
\hline$P$ & 5,37 & 37,49 & 3,0 & 12,0 & 3,79 & 38,59 & 2,0 & 7,0 \\
\hline K & 0,54 & 36,63 & 0,3 & 1,1 & 0,57 & 29,66 & 0,3 & 1,0 \\
\hline $\mathrm{Ca}$ & 4,75 & 33,76 & 2,0 & 8,0 & 5,20 & 27,88 & 3,0 & 8,0 \\
\hline $\mathrm{Mg}$ & 6,75 & 96,15 & 1,0 & 35,0 & 2,87 & 71,42 & 2,0 & 5,0 \\
\hline $\mathrm{H}^{+}+\mathrm{Al}^{+3}$ & 28,17 & 12,85 & 20,0 & 38,0 & 31,42 & 19,22 & 25,0 & 42,0 \\
\hline СТC & 40,12 & 16,79 & 26,0 & 65,4 & 40,07 & 23,12 & 31,4 & 51,0 \\
\hline SB & 11,94 & 46,59 & 4,6 & 39,1 & 8,61 & 45,74 & 4,7 & 13,8 \\
\hline V & 29,08 & 28,67 & 15,0 & 60,0 & 21,70 & 19,45 & 14,0 & 37,0 \\
\hline B & 0,18 & 25,52 & 0,10 & 0,20 & 0,28 & 20,48 & 0,32 & 0,39 \\
\hline $\mathrm{Cu}$ & 0,44 & 12,51 & 0,3 & 0,6 & 0,82 & 18,69 & 0,6 & 1,0 \\
\hline $\mathrm{Fe}$ & 46,98 & 11,40 & 26,7 & 63,4 & 62,52 & 10,25 & 49,0 & 78,1 \\
\hline $\mathrm{Mn}$ & 1,35 & 21,49 & 0,8 & 1,8 & 1,43 & 23,64 & 0,9 & 2,2 \\
\hline $\mathrm{Zn}$ & 0,59 & 42,25 & 0,2 & 1,1 & 1,09 & 40,17 & 0,5 & 1,6 \\
\hline
\end{tabular}

A análise estatística dos dados indicou haver diferenças significativas para os valores de fósforo, magnésio, boro, cobre, ferro e zinco, matéria orgânica, $\mathrm{pH}, \mathrm{H}^{+}+\mathrm{Al}^{3+}$, SB e $\mathrm{V} \%$ nas áreas amostradas, na camada de 10 a 20 $\mathrm{cm}$.

Os valores médios determinados, para as duas áreas amostradas, podem ser classificados como muito baixos para fósforo e potássio. $\mathrm{O} \mathrm{pH}$ na área não recentemente adubada é considerado alto enquanto que na recentemente adubada é médio. Quanto ao magnésio os valores apresentados são considerados médio e baixo respectivamente, para a área não recentemente adubada e recentemente adubada. O V\% apresentado é considerado baixo para ambas as áreas amostradas, de acordo com Raij et al. 
(1996). Os teores de matéria orgânica são considerados baixos conforme dados apresentados por Siqueira et al. (1987).

Tabela 4. Níveis de significância associados aos testes de comparação de médias (teste t) entre NRA e RA para as variáveis analisadas na camada de solo de 10 a $20 \mathrm{~cm}$.

\begin{tabular}{|c|c|c|}
\hline Variáveis & $\mathrm{t}$ & Prob $>[t]$ \\
\hline $\mathrm{pH}$ & $-4,4392$ & 0,0001 \\
\hline MO & 3,0597 & 0,0037 \\
\hline$P$ & $-2,8399$ & 0,0067 \\
\hline K & 0,4296 & 0,6695 \\
\hline $\mathrm{Ca}$ & 1,0340 & 0,3065 \\
\hline $\mathrm{Mg}$ & $-4,0035$ & 0,0002 \\
\hline $\mathrm{H}^{+}+\mathrm{Al}^{+3}$ & 2,2723 & 0,0278 \\
\hline СTC & $-0,0254$ & 0,9799 \\
\hline SB & $-3,1217$ & 0,0031 \\
\hline V & $-3,5422$ & 0,0009 \\
\hline B & 7,2396 & 0,0001 \\
\hline $\mathrm{Cu}$ & 13,4099 & 0,0001 \\
\hline $\mathrm{Fe}$ & 6,6455 & 0,0001 \\
\hline $\mathrm{Mn}$ & 0,9561 & 0,3440 \\
\hline $\mathrm{Zn}$ & 4,8501 & 0,0001 \\
\hline
\end{tabular}

Os momentos estatísticos das variáveis analisadas, nas áreas não recentemente adubada (NRA) e recentemente adubada (RA) para as lâminas de folhas recém-expandidas, são apresentados na Tabela 5. O nível de significância para o teste de comparação de médias (teste t) entre NRA e RA é mostrado na Tabela 6. 
Tabela 5. Momentos estatísticos das concentrações de nutrientes nas lâminas de folhas recém-expandidas nas áreas não adubada (NRA) recentemente e adubada recentemente (RA).

\begin{tabular}{|c|c|c|c|c|c|c|c|c|}
\hline \multirow[t]{2}{*}{ Variáveis } & \multicolumn{4}{|c|}{ NRA } & \multicolumn{4}{|c|}{ RA } \\
\hline & $\begin{array}{l}\text { Média } \\
\mathrm{N}=24\end{array}$ & $\begin{array}{c}\text { C.V. } \\
\%\end{array}$ & MIN. & MÁX. & $\begin{array}{l}\text { Média } \\
\mathrm{N}=24\end{array}$ & $\begin{array}{c}\text { C.V. } \\
\%\end{array}$ & MIN. & MÁX. \\
\hline $\mathrm{N}$ & 15,64 & 10,53 & 12,96 & 20,65 & 22,14 & 10,23 & 18,47 & 25,41 \\
\hline$P$ & 2,93 & 12,44 & 2,21 & 3,56 & 2,37 & 13,25 & 1,58 & 3,08 \\
\hline $\mathrm{K}$ & 12,18 & 15,60 & 7,65 & 16,07 & 16,00 & 20,12 & 8,42 & 19,13 \\
\hline $\mathrm{Ca}$ & 4,02 & 17,40 & 2,75 & 5,06 & 3,14 & 16,11 & 2,05 & 4,41 \\
\hline $\mathrm{Mg}$ & 4,47 & 16,32 & 3,25 & 5,78 & 3,80 & 17,45 & 2,13 & 5,11 \\
\hline S & 1,07 & 15,12 & 0,74 & 1,50 & 1,10 & 12,50 & 0,63 & 1,44 \\
\hline $\mathrm{Cu}$ & 3,98 & 41,29 & 2,90 & 5,70 & 6,94 & 23,52 & 4,40 & 19,60 \\
\hline $\mathrm{Fe}$ & 80,50 & 89,36 & 58,30 & 118,30 & 110,62 & 44,71 & 50,30 & 758,50 \\
\hline $\mathrm{Mn}$ & 62,80 & 23,56 & 37,20 & 77,90 & 90,95 & 35,10 & 34,50 & 138,40 \\
\hline $\mathrm{Zn}$ & 18,45 & 23,23 & 12,10 & 40,20 & 25,60 & 24,38 & 13,40 & 45,90 \\
\hline
\end{tabular}

${ }^{*} \mathrm{~N}, \mathrm{P}, \mathrm{K}, \mathrm{Ca}, \mathrm{Mg}, \mathrm{S}\left(\mathrm{g} \mathrm{kg}^{-1}\right) ; \mathrm{Cu}, \mathrm{Fe}, \mathrm{Mn}, \mathrm{Zn}\left(\mathrm{mg} \mathrm{kg}^{-1}\right) ; \mathrm{C} . \mathrm{V} .(\%)$.

Tabela 6. Níveis de significância associados aos testes de comparação de médias (teste t) entre NRA e RA para as variáveis analisadas nas lâminas de folhas recém-expandidas do capim-braquiária.

\begin{tabular}{ccc}
\hline Variáveis & $\mathrm{t}$ & Prob>[t] \\
\hline $\mathrm{N}$ & 10,2103 & 0,0001 \\
$\mathrm{P}$ & $-6,3120$ & 0,0001 \\
$\mathrm{~K}$ & 5,7706 & 0,0001 \\
$\mathrm{Ca}$ & $-4,1964$ & 0,0001 \\
$\mathrm{Mg}$ & $-3,2121$ & 0,0024 \\
$\mathrm{~S}$ & 0,3247 & 0,7469 \\
$\mathrm{Cu}$ & 8,6711 & 0,0001 \\
$\mathrm{Fe}$ & 4,7005 & 0,0001 \\
$\mathrm{Mn}$ & 5,5473 & 0,0001 \\
$\mathrm{Zn}$ & 5,4208 & 0,0001 \\
\hline
\end{tabular}

${ }^{*} \mathrm{~N}, \mathrm{P}, \mathrm{K}, \mathrm{Ca}, \mathrm{Mg}$ e S $\left(\mathrm{g} \mathrm{kg}^{-1}\right) ; \mathrm{Cu}, \mathrm{Fe}, \mathrm{Mn}$ e Zn $\left(\mathrm{mg} \mathrm{kg}^{-1}\right)$. 
A análise estatística dos resultados indicou haver diferenças significativas entre os valores de concentração de nitrogênio, fósforo, potássio, cálcio e magnésio na lâmina de folhas recém-expandidas entre as áreas amostradas.

Comparando os resultados de concentração de nitrogênio nas lâminas das folhas recém-expandidas, nas áreas não recentemente adubada e recentemente adubada, com o nível crítico desse nutriente obtido por Santos (1997), observa-se que a concentração de nitrogênio nas lâminas de folhas recém-expandidas da área não recentemente adubada encontra-se próxima da faixa de deficiência, enquanto aquela correspondente à área recentemente adubada está acima do nível crítico.

No caso do fósforo, embora haja diferença entre as plantas das áreas em estudo, os mesmos se encontram em valores acima dos encontrados por Monteiro et al. (1995), para o nível crítico nessa forrageira.

As concentrações de potássio das lâminas de folhas recém-expandidas, nas áreas não recentemente adubada e recentemente adubada encontram-se abaixo dos valores relatados por Mattos (1997), para o nível crítico de potássio em Brachiaria decumbens.

As concentrações de cálcio e magnésio encontradas no capim foram diferentes entre as áreas em estudo, sendo mais alta para a forrageira da área não recentemente adubada. Todavia os valores de cálcio estão dentro da faixa de concentração considerada normal para forrageira por Gallo et al. (1974), enquanto para o magnésio os valores encontrados estão bem acima da faixa considerada normal por esses autores.

Os valores de concentração de enxofre apresentados não mostraram diferenças para as áreas em estudo. Entretanto esses valores, encontram-se acima do nível crítico obtido por Santos (1997). 
A análise estatística dos resultados indicou haver diferenças significativas entre os valores da concentração de cobre, ferro, manganês e zinco na lâmina de folhas recém-expandidas entre as áreas amostradas.

Quanto aos valores de cobre, ferro, manganês e zinco, embora tenham apresentado diferenças significativas entre as áreas esses valores encontramse dentro dos valores considerados adequados para essas forrageiras (Gallo et al., 1974).

A análise estatística dos resultados indicou haver diferenças significativas em termos das concentrações de nitrogênio, potássio, cobre e zinco nas raízes, entre as áreas amostradas (Tabelas 7 e 8).

Tabela 7. Momentos estatísticos das concentrações de nutrientes nas raízes nas áreas não adubada (NRA) recentemente e adubada recentemente (RA).

\begin{tabular}{|c|c|c|c|c|c|c|c|c|}
\hline \multirow[t]{2}{*}{ Variáveis } & \multicolumn{4}{|c|}{ NRA } & \multicolumn{4}{|c|}{ RA } \\
\hline & $\begin{array}{l}\text { Média } \\
\mathrm{N}=24\end{array}$ & $\begin{array}{l}\text { C.V. } \\
\%\end{array}$ & MIN. & MÁX. & $\begin{array}{l}\text { Média } \\
\mathrm{N}=24\end{array}$ & $\begin{array}{c}\text { C.V. } \\
\%\end{array}$ & MIN. & MÁX. \\
\hline $\mathrm{N}$ & 3,83 & 28,59 & 2,44 & 5,91 & 4,86 & 18,41 & 2,04 & 7,17 \\
\hline$P$ & 0,58 & 23,62 & 0,40 & 1,10 & 0,53 & 16,17 & 0,39 & 0,75 \\
\hline K & 3,75 & 31,73 & 2,30 & 6,89 & 4,59 & 32,25 & 3,06 & 7,65 \\
\hline $\mathrm{Ca}$ & 0,81 & 33,50 & 0,61 & 1,18 & 0,73 & 38,74 & 0,44 & 2,08 \\
\hline $\mathrm{Mg}$ & 0,57 & 23,46 & 0,36 & 0,79 & 0,52 & 20,12 & 0,36 & 0,94 \\
\hline n & 1,24 & 34,57 & 0,83 & 3,44 & 1,04 & 35,98 & 0,75 & 1,33 \\
\hline $\mathrm{Cu}$ & 20,28 & 29,75 & 9,10 & 33,30 & 25,38 & 26,31 & 11,40 & 43,10 \\
\hline $\mathrm{Mn}$ & 48,72 & 41,32 & 33,50 & 66,80 & 52,48 & 38,79 & 38,30 & 65,30 \\
\hline $\mathrm{Zn}$ & 3,83 & 15,84 & 18,00 & 75,80 & 4,86 & 12,46 & 27,10 & 68,20 \\
\hline
\end{tabular}

${ }^{*} \mathrm{~N}, \mathrm{P}, \mathrm{K}, \mathrm{Ca}, \mathrm{Mg}, \mathrm{S}\left(\mathrm{g} \mathrm{kg}^{-1}\right) ; \mathrm{Cu}, \mathrm{Fe}, \mathrm{Mn}, \mathrm{Zn}\left(\mathrm{mg} \mathrm{kg}^{-1}\right)$; C.V. (\%). 
Tabela 8. Níveis de significância associados aos testes de comparação de médias (teste $t$ ) entre NRA e RA para as variáveis analisadas nas raízes do capim-braquiária.

\begin{tabular}{ccc}
\hline Variáveis & $\mathrm{t}$ & Prob>[t] \\
\hline $\mathrm{N}$ & 3,2353 & 0,0025 \\
$\mathrm{P}$ & $-1,3286$ & 0,1905 \\
$\mathrm{~K}$ & 2,2160 & 0,0317 \\
$\mathrm{Ca}$ & $-1,1944$ & 0,2385 \\
$\mathrm{Mg}$ & $-1,0891$ & 0,2818 \\
$\mathrm{~S}$ & $-1,6349$ & 0,1089 \\
$\mathrm{Cu}$ & 2,7234 & 0,0091 \\
$\mathrm{Mn}$ & 1,6776 & 0,1002 \\
$\mathrm{Zn}$ & 3,2353 & 0,0023 \\
\hline
\end{tabular}

${ }^{*} \mathrm{~N}, \mathrm{P}, \mathrm{K}, \mathrm{Ca}, \mathrm{Mg}$ e S $\left(\mathrm{g} \mathrm{kg}^{-1}\right) ; \mathrm{Cu}, \mathrm{Fe}, \mathrm{Mn}$ e Zn $\left(\mathrm{mg} \mathrm{kg}^{-1}\right)$.

Esses valores determinados nas raízes estão próximos dos valores observados por Premazzi (1991), quando estudou efeito da calagem em algumas forrageiras, entre as quais a Brachiaria brizantha.

O teor de clorofila, medido na posição do terço médio do limbo foliar da segunda folha recém-expandida a partir do ápice, nas áreas não recentemente adubada (NRA) foi de 26,0 enquanto na recentemente adubada (RA) foi de 40,1 e ambos diferem significativamente entre si (teste $t, P<0,01$ ). Esses valores SPAD mostraram uma correlação significativa $\left(r=0,63^{* * *}\right.$ e $r=0,61^{* * *}$, respectivamente) com as concentrações de nitrogênio nas lâminas foliares.

Como os teores de matéria orgânica, fósforo, cobre, ferro e zinco no solo apresentaram variação significativa entre as áreas estudadas, procurou-se correlacionar esses atributos químicos do solo nas camadas de $0-10 \mathrm{~cm}$ e 10-20cm em ambas as áreas (NRA e RA) com as concentrações de nitrogênio, fósforo, cobre, ferro e zinco nas lâminas de folhas recém-expandidas e nas raízes do capim-braquiária. 
Verificaram-se baixos coeficientes de correlação entre os atributos químicos do solo matéria orgânica e teores de fósforo, cobre, ferro e zinco nas camadas de $0-10 \mathrm{~cm}$ e $10-20 \mathrm{~cm}$ das duas áreas com as concentrações de nitrogênio, fósforo, cobre, ferro e zinco nas lâminas de folhas recém-expandidas $(P>0,10)$ e as concentrações de nitrogênio, cobre e zinco nas raízes $(P>0,20)$ da forrageira nas áreas em estudo. Porém, a correlação entre teor de fósforo no solo nas camadas de $0-10 \mathrm{~cm}$ com esse teor na camada de $10-20 \mathrm{~cm}$ mostrouse significativa tanto na área não recentemente adubada $\left(r=0,61^{* * *}\right)$ como na recentemente adubada $\left(r=0,82^{* * *}\right)$.

A correlação entre os teores de zinco nas camadas de $0-10 \mathrm{~cm}$ e $10-20 \mathrm{~cm}$ do solo da área recentemente adubada e a concentração de fósforo nas lâminas de folhas recém-expandidas do capim coletado na mesma área revelou coeficientes da ordem de $0,62^{* * *}$ e $0,61^{* * *}$, respectivamente. Na área não recentemente adubada esses coeficientes foram muito baixos e sem significância estatística $(P>0,30)$.

$\mathrm{Na}$ área recentemente adubada detectaram-se altos coeficientes de correlação entre as concentrações nas lâminas de folhas recém-expandidas para os micronutrientes cobre e ferro $\left(r=0,86^{* * *}\right)$, e zinco $\left(r=0,83^{* * *}\right)$ e ferro e zinco $\left(r=0,81^{* * *}\right)$. Por outro lado, na área não recentemente adubada essas correlações apresentaram coeficientes de valor muito baixo e estatisticamente não significativos $(P>0,08)$.

Outro aspecto que cabe ressaltar, em termos de correlação, é o da ocorrência de muito baixos valores para o coeficiente de correlação entre as concentrações de nitrogênio, fósforo, cobre, ferro e zinco nas lâminas de folhas recém-expandidas e nas raízes coletadas nos mesmos pontos da pastagem do capim-braquiária, independentemente de a área ter sido ou não recentemente adubada. 


\subsection{Segunda etapa}

\subsubsection{Experimento com forrageira proveniente de área não recentemente adubada}

\subsubsection{Produção de matéria seca da parte aérea}

A análise de variância da produção de matéria seca da parte aérea da Brachiaria decumbens Stapf. cultivada nos cilindros provenientes da área não recentemente adubada mostrou significância para a interação entre doses de nitrogênio e doses de enxofre, tanto para o primeiro $(P<0,01)$ como para o segundo crescimento $(P<0,01)$. A produção de matéria seca da parte aérea foi significativamente $(P<0,01)$ influenciada pelas doses de nitrogênio no terceiro crescimento.

No primeiro crescimento, o capim respondeu às doses de nitrogênio, segundo modelo quadrático dentro de cada dose de enxofre (Figura 3). A mais alta produção de matéria seca da parte aérea no primeiro crescimento foi alcançada mediante o suprimento de nitrogênio de $192 \mathrm{mg} \mathrm{dm}^{-3}$ de solo e em presença da dose de enxofre de $30 \mathrm{mg} \mathrm{dm}^{-3}$. Por outro lado quando se utilizou a dose de enxofre de $60 \mathrm{mg} \mathrm{dm}^{-3}$ a produção de matéria seca foi semelhante à obtida com a dose de enxofre de $30 \mathrm{mg} \mathrm{dm}^{-3}$, porém o capim na dose de enxofre de $60 \mathrm{mg} \mathrm{dm}^{-3}$ necessitou de menos nitrogênio em relação a dose de $30 \mathrm{mg} \mathrm{dm}^{-3}$ para produzir a mesma quantidade de matéria seca. Na não aplicação de enxofre verificou-se uma redução de $23 \%$ na produção da matéria seca da parte aérea em relação a obtida com as outras doses de enxofre utilizadas, em similares doses de nitrogênio. 

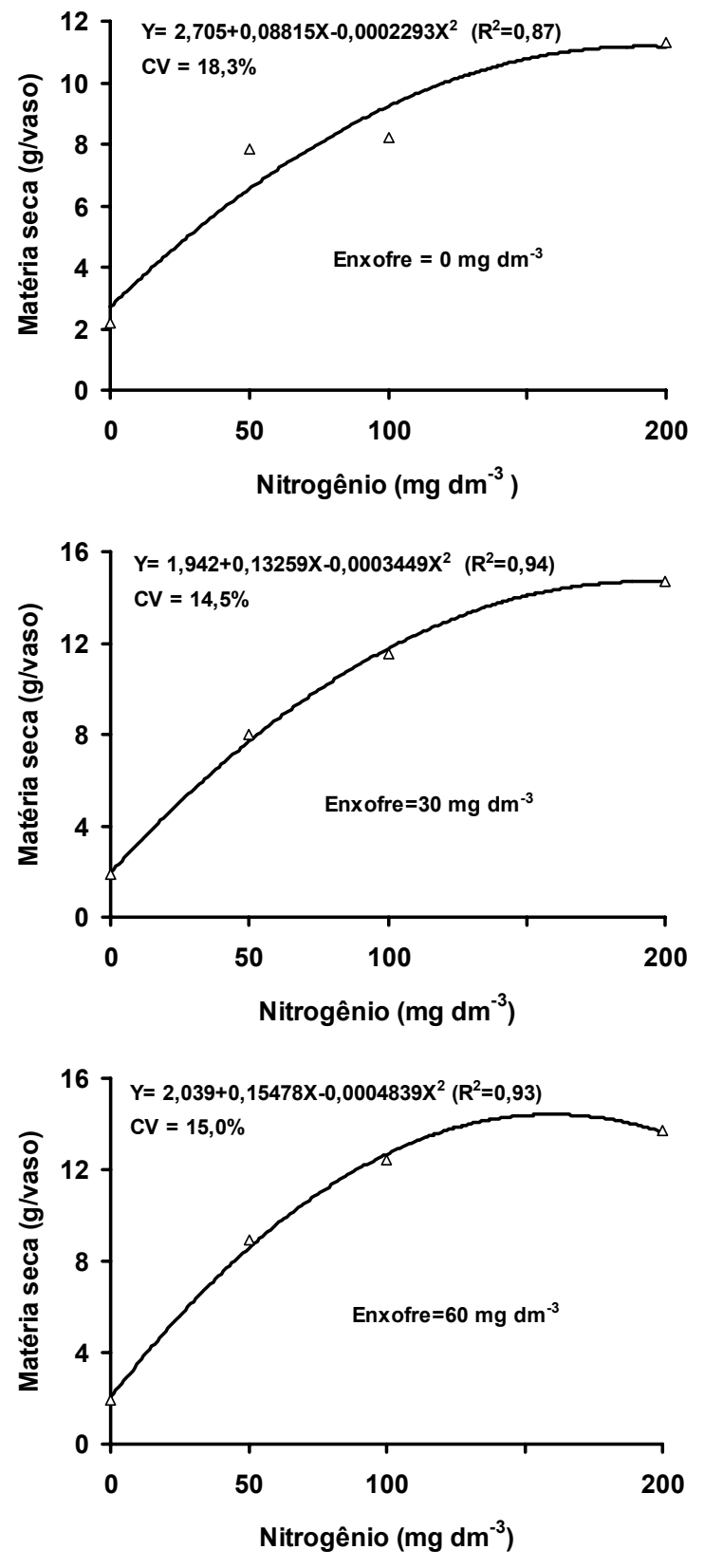

Figura 3 - Produção de matéria seca da parte aérea da Brachiaria decumbens, no primeiro crescimento, em função das doses de nitrogênio dentro de cada dose de enxofre aplicadas no cilindro proveniente da área não recentemente adubada. 
No desdobramento da interação para o estudo de enxofre dentro de cada dose de nitrogênio, em termos da produção de matéria seca da parte aérea do primeiro crescimento, verificou-se efeito significativo $(P<0,01)$ do enxofre na dose de nitrogênio de $100 \mathrm{mg} \mathrm{dm}^{-3}$, sendo este efeito representado através de equação do primeiro grau (Figura 4). Assim, a máxima produção de matéria seca da parte aérea do primeiro crescimento ocorreria em dose de enxofre mais elevada que as utilizadas no experimento, quando se utilizou o nitrogênio em $100 \mathrm{mg} \mathrm{dm}^{-3}$. Dentro das doses de nitrogênio de 0,50 e $200 \mathrm{mg} \mathrm{dm}^{-3}$ não foi verificado efeito significativo $(P>0,05)$ das doses de enxofre para a produção de matéria seca da parte aérea, no primeiro crescimento.

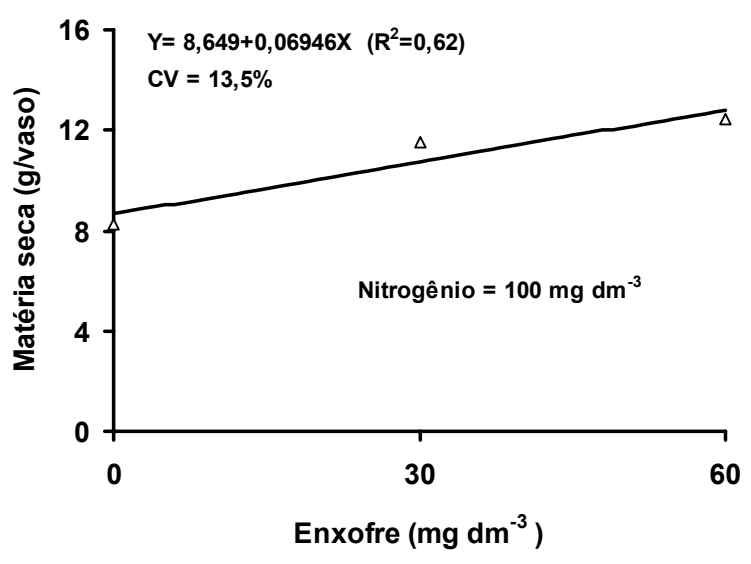

Figura 4 - Produção de matéria seca da parte aérea da Brachiaria decumbens, no primeiro crescimento, em função das doses de enxofre dentro da dose de nitrogênio de $100 \mathrm{mg} \mathrm{dm}^{-3}$ aplicada no cilindro proveniente da área não recentemente adubada. 
No segundo crescimento, as equações demonstraram ajustes a modelo linear para a produção de matéria seca da parte aérea da Brachiaria decumbens, em função das doses de nitrogênio dentro das três doses de enxofre (Figura 5).

A produção de matéria seca da parte aérea do capim, no segundo crescimento, mostrou significância $(P<0,01)$ para as doses de nitrogênio dentro das doses de enxofre utilizadas. Como as relações entre o suprimento de nitrogênio dentro de cada dose de enxofre e a produção da parte aérea foram lineares, a máxima produção de matéria seca da parte aérea ocorreria em dose de nitrogênio mais elevada que as utilizadas (Figura 5). Quando se utilizou a dose de nitrogênio de $200 \mathrm{mg} \mathrm{dm}^{-3}$ juntamente com a dose de enxofre de $60 \mathrm{mg} \mathrm{dm}^{-3}$ a produção de matéria seca da parte aérea foi cerca de $22 \%$ mais elevada que na mesma dose de nitrogênio sem aplicação de enxofre.

No segundo crescimento verificou-se efeito significativo $(P<0,01)$ das doses de enxofre dentro de dose de nitrogênio $200 \mathrm{mg} \mathrm{dm}^{-3}$ e este efeito foi representado por uma equação de segundo grau. A mais elevada produção de matéria seca ocorreu em $60 \mathrm{mg} \mathrm{dm}^{-3}$ de enxofre quando a dose de nitrogênio foi de $200 \mathrm{mg} \mathrm{dm}^{-3}$, enquanto que a dose de $30 \mathrm{mg} \mathrm{dm}^{-3}$ de enxofre proporcionou a mais baixa produção de matéria seca da parte aérea dentro dessa mesma dose de nitrogênio (Figura 6).

Hoffmann (1992) obteve a máxima produção da Brachiaria decumbens quando empregou a dose de nitrogênio de $437 \mathrm{mg} \mathrm{kg}^{-1}$ de solo e alcançou o máximo rendimento da parte aérea com adição de enxofre de $76 \mathrm{mg} \mathrm{kg}^{-1}$ de solo. Faquin et al. (1995) observaram, em estudo com esse mesmo capim, que as máximas produções de matéria seca foram obtidas nas doses de enxofre de 65 e $100 \mathrm{mg} \mathrm{kg}^{-1}$ de solo, respectivamente no primeiro e no segundo crescimentos. 

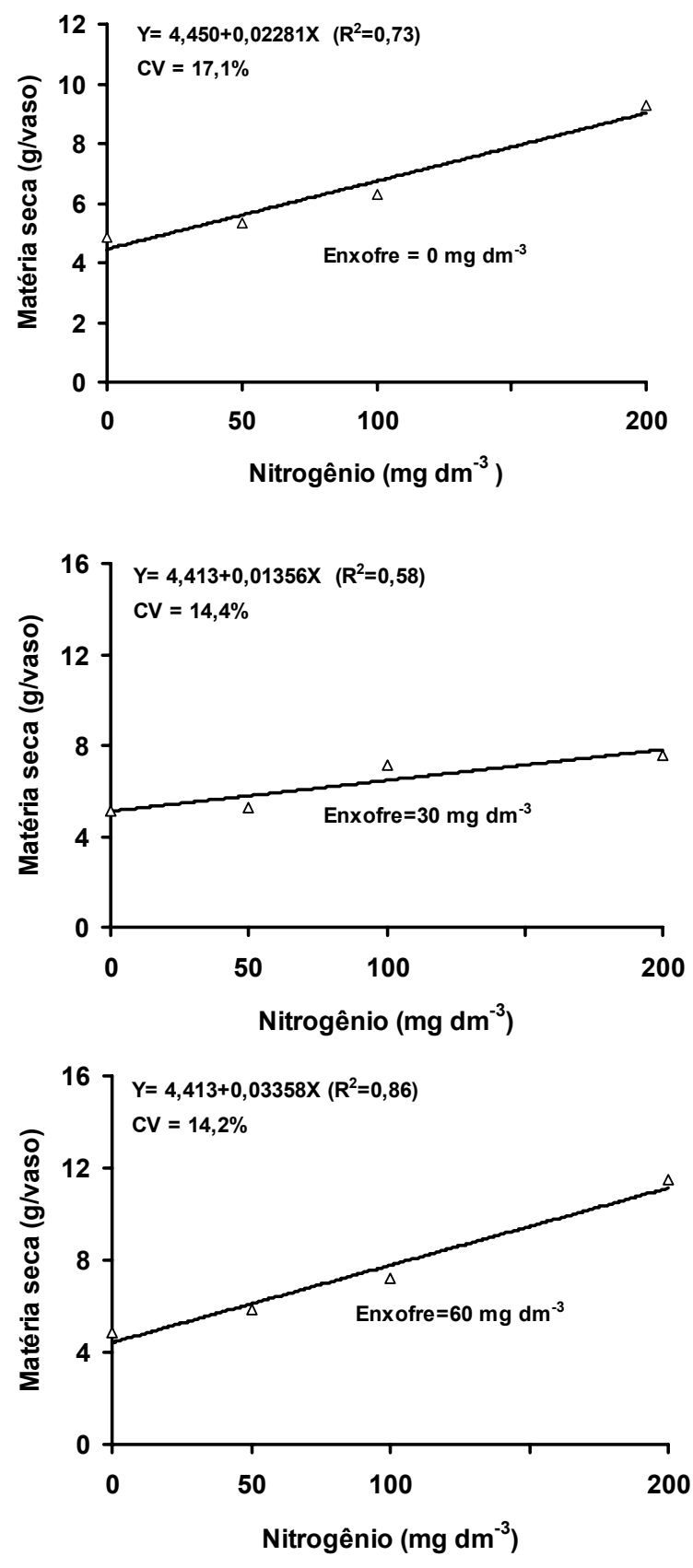

Figura 5 - Produção de matéria seca da parte aérea da Brachiaria decumbens, no segundo crescimento, em função das doses de nitrogênio dentro de cada dose de enxofre aplicadas no cilindro proveniente da área não recentemente adubada. 


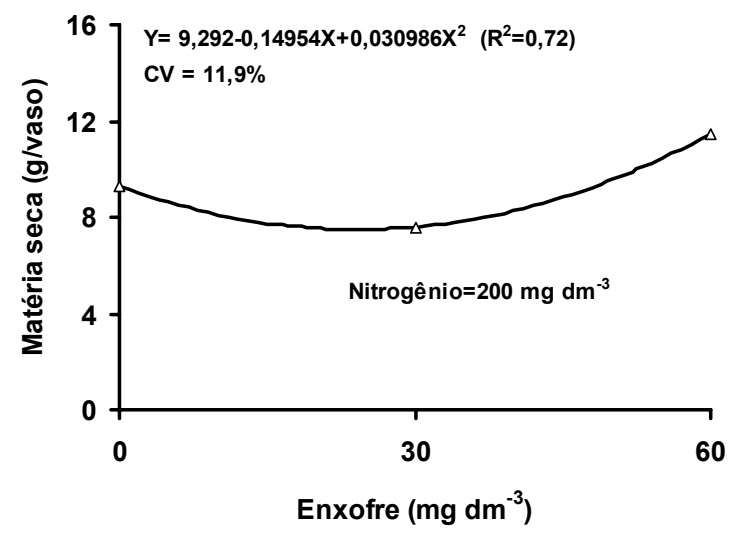

Figura 6 - Produção de matéria seca da parte aérea da Brachiaria decumbens, no segundo crescimento, em função das doses de enxofre dentro da dose de nitrogênio de $200 \mathrm{mg} \mathrm{dm}^{-3}$ aplicada no cilindro proveniente da área não recentemente adubada.

No terceiro crescimento, a produção da parte aérea da Brachiaria decumbens respondeu às doses de nitrogênio segundo um modelo quadrático (Figura 7). O ponto de máxima produção da parte aérea ocorreu com o nitrogênio aplicado na adubação em $141 \mathrm{mg} \mathrm{dm}^{-3}$.

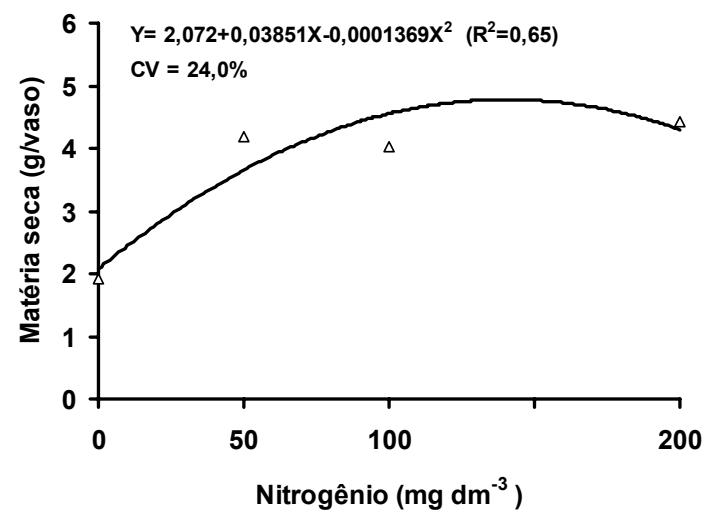

Figura 7 - Produção de matéria seca da parte aérea da Brachiaria decumbens, no terceiro crescimento, em função das doses do nitrogênio aplicado no cilindro proveniente da área não recentemente adubada. 


\subsubsection{Estimativa do teor de clorofila através do valor SPAD}

Para os resultados das leituras de clorofila através do Chlorophyll Meter SPAD-502 na lâmina foliar do capim-braquiária cultivado nos cilindros coletados na área não recentemente adubada, por ocasião do primeiro e do segundo crescimentos, ocorreu significância $(P<0,01)$ para a interação entre as doses de nitrogênio e as de enxofre. No terceiro crescimento o teor de clorofila sofreu variação significativa $(P<0,01)$, em função das doses de nitrogênio.

No desdobramento da interação, para nitrogênio dentro das doses de enxofre verificaram-se efeitos significativos $(P<0,01)$ das doses de nitrogênio em cada uma das três doses de enxofre, no primeiro crescimento. Esses efeitos são representados por equações do segundo grau nas doses de 0 e $30 \mathrm{mg}$ $\mathrm{dm}^{-3}$ e do primeiro grau na dose de enxofre de $60 \mathrm{mg} \mathrm{dm}^{-3}$ (Figura 8).

$\mathrm{Na}$ dose de nitrogênio de $200 \mathrm{mg} \mathrm{dm}^{-3}$ na não aplicação de enxofre encontra-se menor valor SPAD que na mesma dose de nitrogênio com as doses de enxofre de 30 e $60 \mathrm{mg} \mathrm{dm}^{-3}$. Isso demonstra uma diminuição no teor de clorofila das folhas recém-expandidas na situação de não suprimento de enxofre consequentemente evidencia a deficiência de enxofre.

Observando os valores SPAD nas doses de enxofre dentro das doses de nitrogênio de 50, 100 e $200 \mathrm{mg} \mathrm{dm}^{-3}$, verificou-se o mais alto valor SPAD quando se aplicou a dose de enxofre de $47 \mathrm{mg} \mathrm{dm}^{-3}$ na presença da dose de nitrogênio de $200 \mathrm{mg} \mathrm{dm}^{-3}$ (Figura 9).

O desdobramento da interação, no segundo crescimento, para nitrogênio dentro de cada uma das três doses de enxofre, verificaram-se efeitos significativos $(P<0,01)$ das doses de nitrogênio em cada uma das doses de enxofre (Figura 10). Esses em relação ao valor SPAD se ajustaram a modelo quadrático no não suprimento de enxofre e a modelos lineares nas doses de enxofre de 30 e $60 \mathrm{mg} \mathrm{dm}^{-3}$. Para as doses de enxofre dentro de cada dose de nitrogênio não houve significância $(P>0,05)$ para o valor SPAD. 

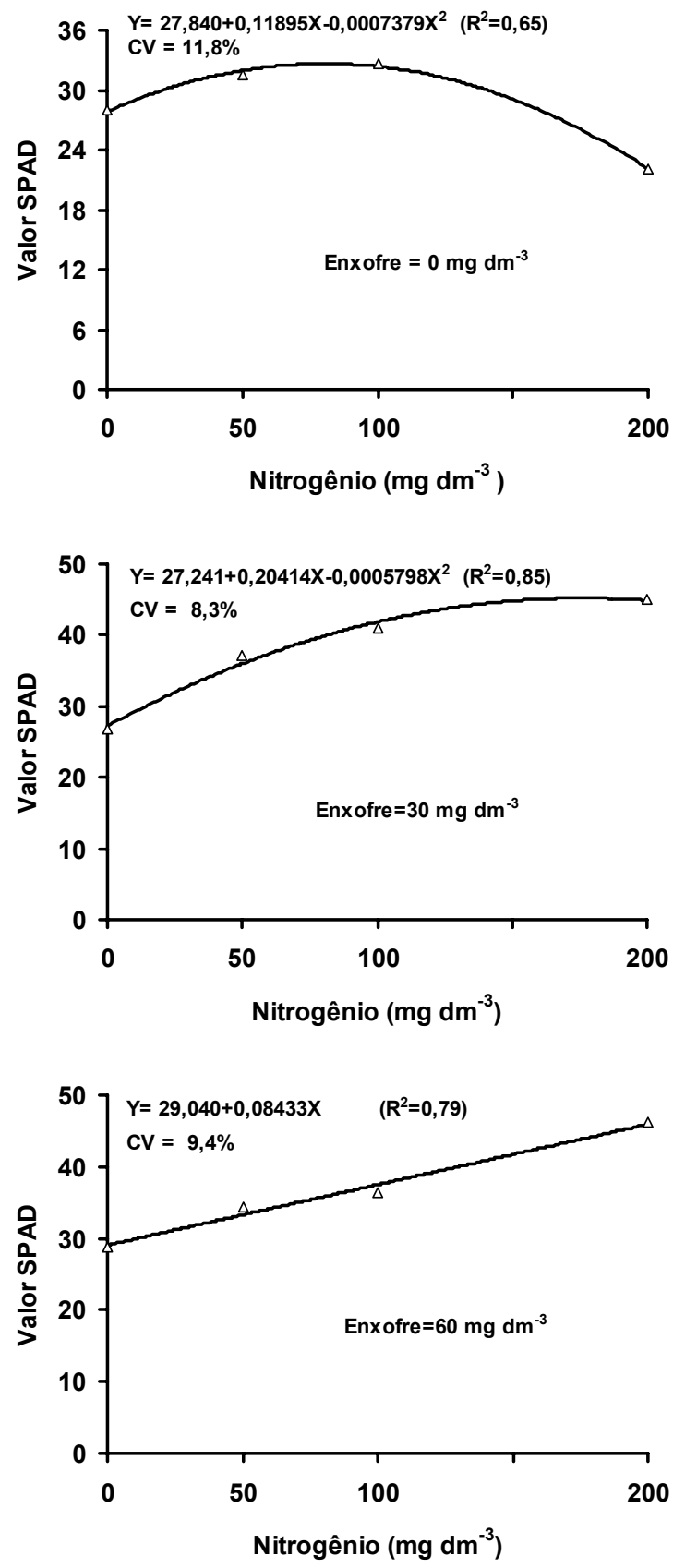

Figura 8 - Valor SPAD na Brachiaria decumbens, no primeiro crescimento, em função das doses de nitrogênio dentro de cada dose de enxofre aplicadas no cilindro proveniente da área não recentemente adubada. 

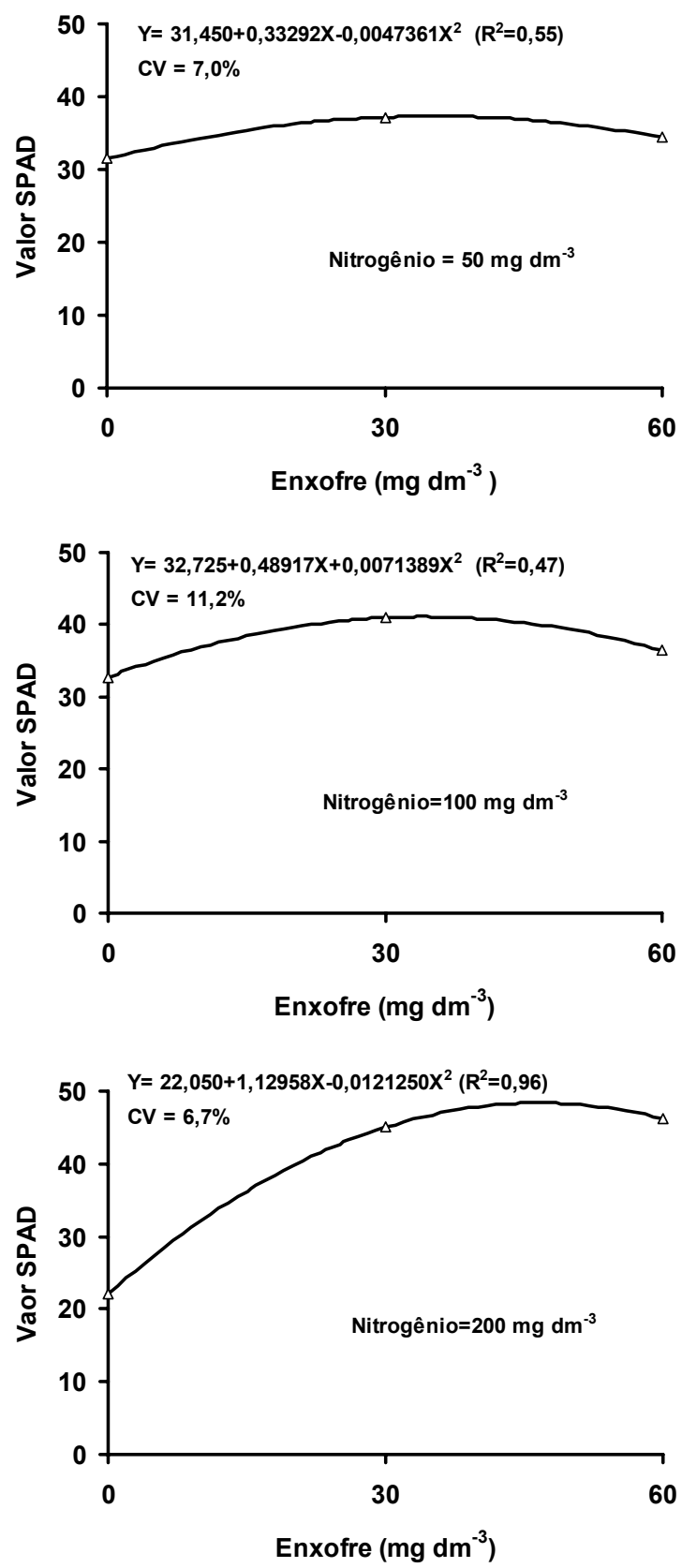

Figura 9 - Valor SPAD na Brachiaria decumbens, no primeiro crescimento, em função das doses de enxofre dentro de cada dose de nitrogênio aplicadas no cilindro proveniente da área não recentemente adubada. 

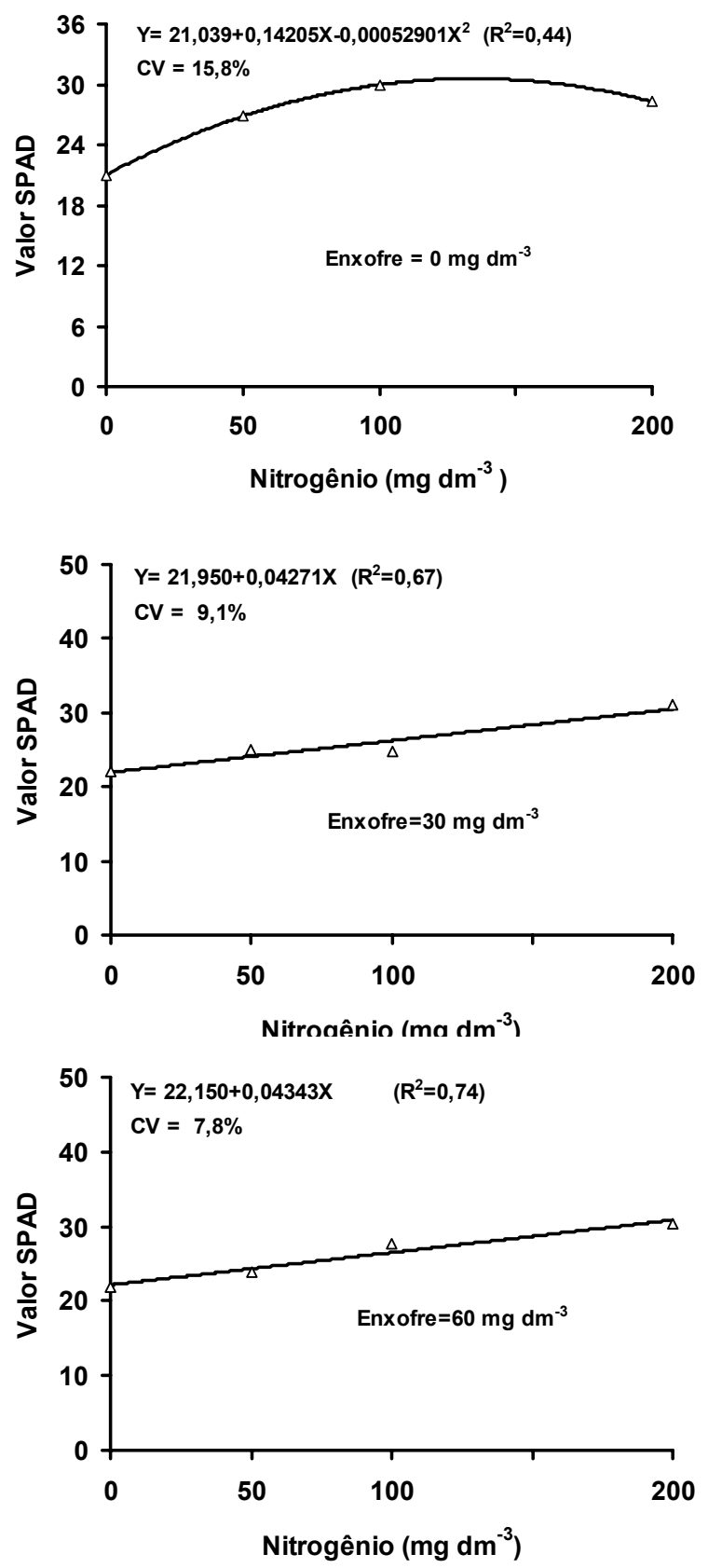

Figura 10 - Valor SPAD na Brachiaria decumbens, no segundo crescimento, em função das doses de nitrogênio dentro de cada dose de enxofre aplicadas no cilindro proveniente da área não recentemente adubada. 
Santos (1997) obteve para o primeiro e segundo crescimentos da Brachiaria decumbens, o teor de clorofila, expresso em valor SPAD, entre 17,0 e 50,2 e 23,9 e 52,0, respectivamente para a condição de omissão e para as doses de nitrogênio para o máximo valor SPAD. O mesmo autor, em outro experimento com doses de enxofre, verificou que as leituras do clorofilômetro no primeiro crescimento da Brachiaria decumbens foram sempre superiores às leituras observadas no segundo crescimento, em função das doses de enxofre utilizadas.

Colozza (1998), estudando o capim-Mombaça, obteve níveis críticos de nitrogênio entre 32,0 e 38,6 unidades SPAD. Manarin (2000), ao cultivar o mesmo capim em doses de nitrogênio, relatou valores entre 41 e 45 unidades SPAD para nível crítico de nitrogênio nas lâminas de folhas recém-expandidas.

Abreu \& Monteiro (1999) relataram que o nível crítico de nitrogênio nas lâminas recém-expandidas aos 28 dias de desenvolvimento no crescimento final do capim-Marandu foi de $23,2 \mathrm{~g} \mathrm{~kg}^{-1}$ e o valor SPAD associado a esse nível foi de 39.

Analisando o valor SPAD na Brachiaria decumbens cultivada nos cilindros provenientes da área não recentemente adubada, pode-se notar variação significativa $(P<0,01)$ em função do suprimento de nitrogênio no meio de crescimento, para o terceiro crescimento (Figura 11).

$O$ valor SPAD na forrageira, no terceiro crescimento variou segundo uma equação do segundo grau em função das doses de nitrogênio no cilindro. $O$ ponto de máximo valor SPAD dessa braquiária ocorreu em presença de $140 \mathrm{mg} \mathrm{dm}^{-3}$. 


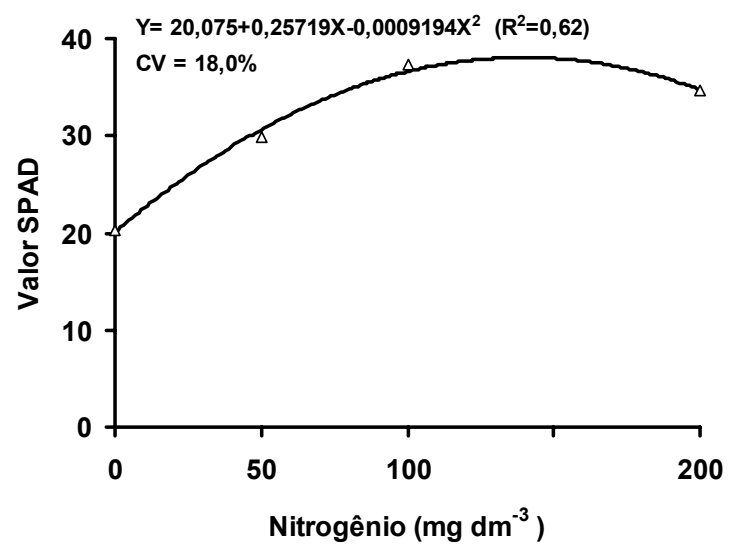

Figura 11 - Teor de clorofila determinado em unidades de valor SPAD na Brachiaria decumbens, no terceiro crescimento, em função das doses de nitrogênio aplicadas no cilindro proveniente da área não recentemente adubada.

\subsubsection{3 Área foliar}

Para a área foliar total da Brachiaria decumbens cultivada nos cilindros retirados da área não recentemente adubada foi significativa $(P<0,01)$ a interação entre doses de nitrogênio e de enxofre no primeiro e no terceiro crescimento. No segundo crescimento das plantas essa interação não foi significativa $(P>0,05)$.

Estudando as doses de nitrogênio dentro de cada dose de enxofre, para a área foliar verificou-se efeito significativo $(P<0,01)$ para as doses de nitrogênio dentro de cada uma das três doses de enxofre, no primeiro crescimento. Esse efeito se ajustou a equações de segundo grau para todas as situações estudadas (Figura 12). Os pontos de máxima área foliar total dessa forrageira ocorreram com as doses de nitrogênio de 122; 215 e $220 \mathrm{mg} \mathrm{dm}^{-3}$, dentro das doses de enxofre de 0; 30 e $60 \mathrm{mg} \mathrm{dm}^{-3}$, respectivamente. Com isso, a maior área foliar total ocorreria acima da dose de nitrogênio utilizada nesse experimento, juntamente com a dose de enxofre de 30 e $60 \mathrm{mg} \mathrm{dm}^{-3}$. 
Nas doses de enxofre dentro de cada dose de nitrogênio, no primeiro crescimento, observou-se significância $(P<0,01)$ para a aplicação de enxofre dentro das doses de nitrogênio de 100 e $200 \mathrm{mg} \mathrm{dm}^{-3}$ (Figuras 13 e 14).

Wilman et al. (1977) obtiveram, em gramíneas do gênero Lolium, aumentos do comprimento e da largura de lâminas foliares verdes, completamente expandidas, com o aumento do suprimento de nitrogênio e do intervalo entre cortes. Manarin (2000) também verificou efeitos significativos de doses de nitrogênio na área foliar do capim-Mombaça.

A disponibilidade de nitrogênio tem pronunciado efeito na taxa de alongamento foliar, podendo resultar em valores três a quatro vezes menores num alto nível de deficiência, quando comparado a um nível não limitante (Gastal et al., 1992).

Pinto et al. (1994) ao estudar a taxa de expansão foliar do capim-Guiné e da capim-setária submetidas a doses de nitrogênio, concluíram que o capimGuiné apresentou folhas maiores que o capim-Setária.

$O$ efeito do nitrogênio na taxa de alongamento foliar, decorre do maior acúmulo deste nutriente na zona de alongamento da folha, mais precisamente na região de divisão celular (Gastal \& Nelson, 1994). Os autores ainda verificaram alta correlação entre a quantidade de nitrogênio contido nessa região e a taxa de expansão foliar.

A deficiência de nitrogênio como a água diminuem progressivamente a taxa fotossintética das folhas, a eficiência de conversão, a interceptação da luz, a produção de biomassa, a área foliar e consequentemente o índice de área foliar (Nabinger \& Medeiros, 1997). 

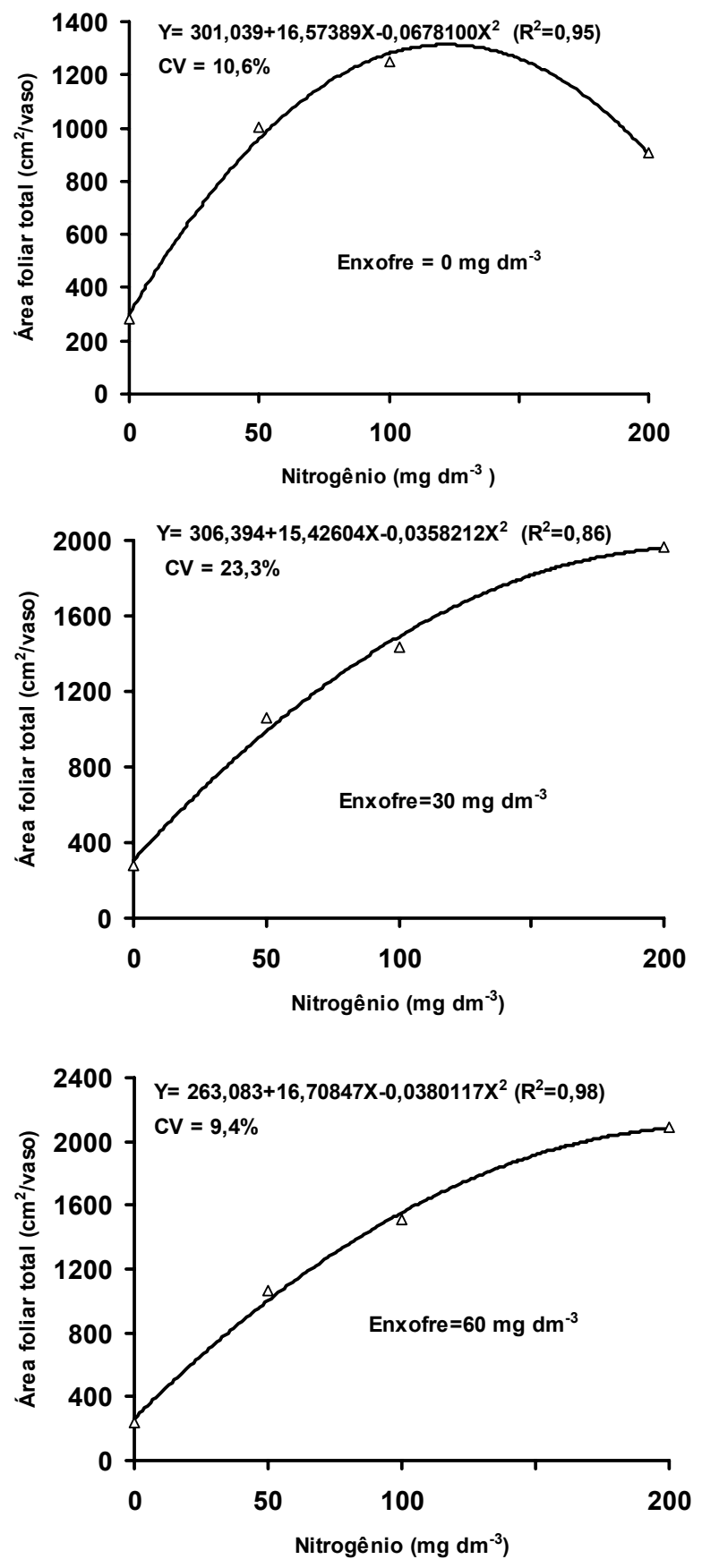

Figura 12 - Área foliar total da Brachiaria decumbens, no primeiro crescimento, em função das doses de nitrogênio dentro de cada dose de enxofre aplicadas no cilindro proveniente da área não recentemente adubada. 


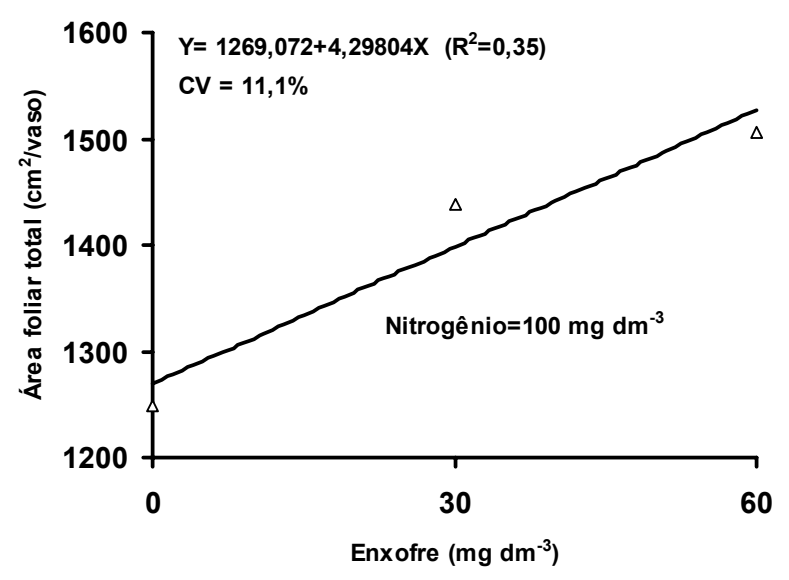

Figura 13 - Área foliar total da Brachiaria decumbens, no primeiro crescimento, em função das doses de enxofre dentro da dose de nitrogênio de $100 \mathrm{mg} \mathrm{dm}^{-3}$ aplicadas no cilindro proveniente da área não recentemente adubada.

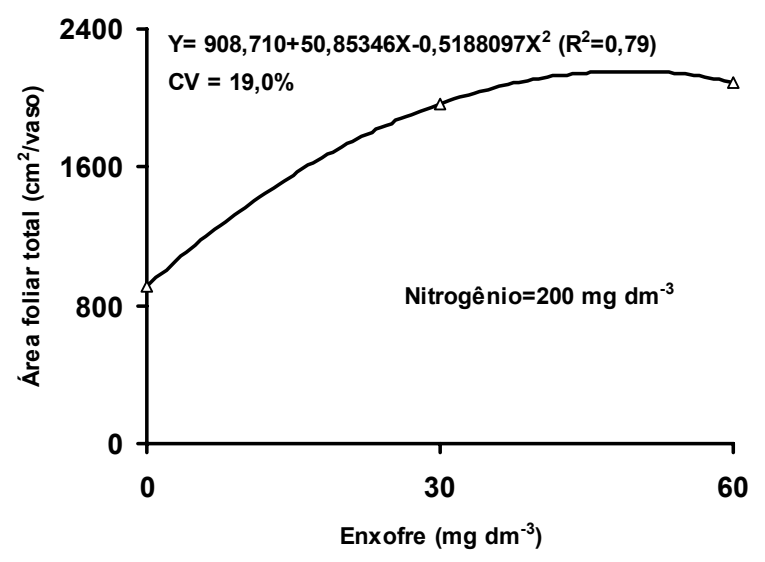

Figura 14 - Área foliar total da Brachiaria decumbens, no primeiro crescimento, em função das doses de enxofre dentro da dose de nitrogênio de $200 \mathrm{mg} \mathrm{dm}^{-3}$ aplicadas no cilindro proveniente da área não recentemente adubada. 
$\mathrm{Na}$ área foliar verificada no segundo crescimento da Brachiaria decumbens, observou-se significância $(P<0,01)$ para as doses de nitrogênio, e esse efeito foi explicado por um modelo linear (Figura 15). Entretanto não se verificou significância $(P>0,05)$ para as doses de enxofre, no que se refere à área foliar total do capim, neste segundo crescimento.

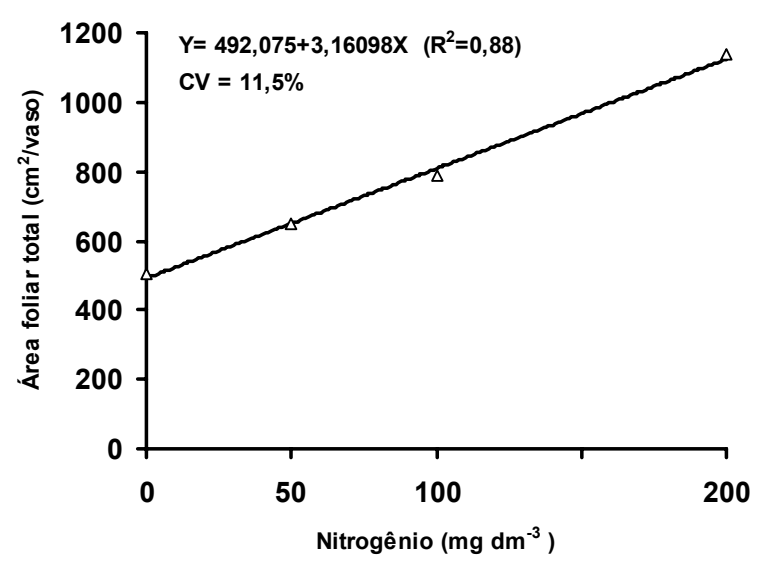

Figura 15 - Área foliar total da Brachiaria decumbens, no segundo crescimento, em função das doses de nitrogênio aplicadas no cilindro proveniente da área não recentemente adubada.

No desdobramento da interação para o estudo de nitrogênio dentro das doses de enxofre em termos de área foliar total no terceiro crescimento, verificou-se efeito significativo $(P<0,05)$ do nitrogênio dentro das doses de enxofre 0,30 e $60 \mathrm{mg} \mathrm{dm}^{-3}$. Esse efeito foi representado por equação do primeiro grau para as doses de nitrogênio dentro das doses de enxofre de $0 \mathrm{e}$ $60 \mathrm{mg} \mathrm{dm}^{-3}$ e equação do segundo grau dentro da dose de $30 \mathrm{mg} \mathrm{dm}^{-3}$ (Figura 16). 

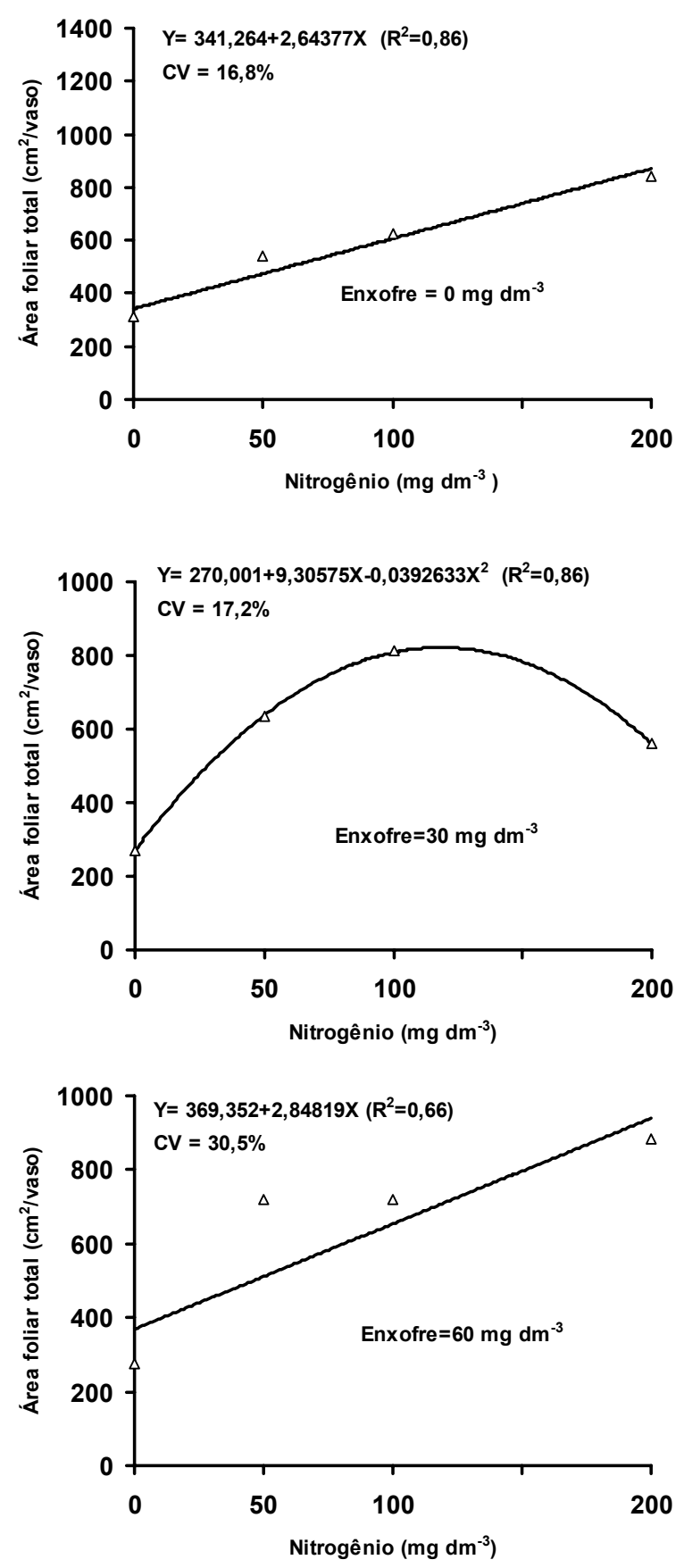

Figura 16 - Área foliar total da Brachiaria decumbens, no terceiro crescimento, em função das doses de nitrogênio dentro de cada dose de enxofre aplicadas no cilindro proveniente da área não recentemente adubada. 


\subsubsection{Número de perfilhos}

O número de perfilhos nas plantas foi significativamente $(P<0,01)$ influenciado no primeiro, segundo e terceiro crescimentos do capim tanto pelas doses de nitrogênio como pelas de enxofre, mas a interação entre nitrogênio e enxofre não foi significativa $(P>0,05)$.

No primeiro crescimento, o número total de perfilhos da Brachiaria decumbens aumentou com o fornecimento de nitrogênio de 0 para $50 \mathrm{mg} \mathrm{dm}^{-3}$, não variando de $50 \mathrm{mg} \mathrm{dm}^{-3}$ a $200 \mathrm{mg} \mathrm{dm}^{-3}$ (Figura 17). Nesse mesmo crescimento, quanto às doses de enxofre utilizadas, o número de perfilhos foi significativamente mais elevado na dose de enxofre de 60 que na não aplicação desse nutriente. Quando não se forneceu enxofre o número de perfilhos foi semelhante ao da dose $30 \mathrm{mg} \mathrm{dm}^{-3}$, a qual por sua vez não deferiu do número de perfilhos na dose de enxofre de $60 \mathrm{mg} \mathrm{dm}^{-3}$ (Figura 18). Faquin et al. (1995a) obtiveram respostas significativas às aplicações de enxofre para o perfilhamento da Brachiaria decumbens, sendo que a dose de enxofre de 98 $\mathrm{mg} \mathrm{kg}^{-1}$ proporcionou o número máximo de perfilhos. Santos (1997) verificou efeito significativo das doses de enxofre no número de perfilhos apenas no segundo crescimento da Brachiaria decumbens. 


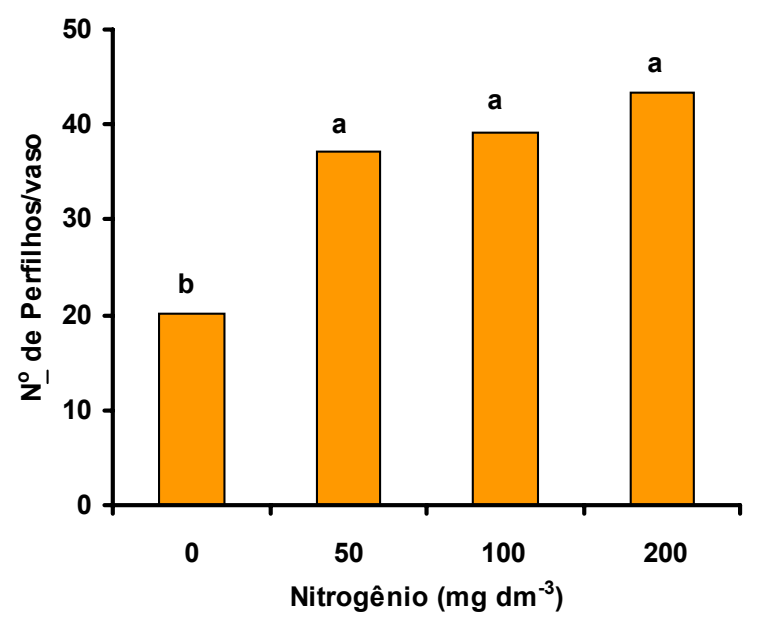

Figura 17 - Número total de perfilhos por cilindro de solo com Brachiaria decumbens, no primeiro crescimento, em função das doses de nitrogênio aplicadas no cilindro proveniente da área não recentemente adubada. Letras diferentes indicam diferença significativa ao nível de $1 \%$ de probabilidade pelo teste de Tukey.

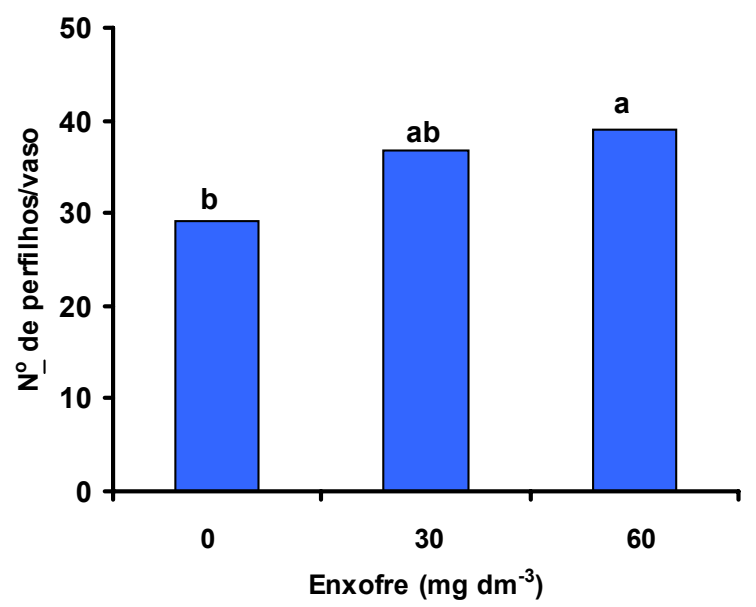

Figura 18 - Número total de perfilhos por cilindro de solo com Brachiaria decumbens, no primeiro crescimento, em função das doses de enxofre aplicadas no cilindro proveniente da área não recentemente adubada. Letras diferentes indicam diferença significativa ao nível de $1 \%$ de probabilidade pelo teste de Tukey. 
No segundo período de crescimento, o número total de perfilhos variou significativamente somente entre a dose de nitrogênio de $200 \mathrm{mg} \mathrm{dm}^{-3}$ e o não fornecimento desse nutriente (Figura 19). Quanto às doses de enxofre o número total de perfilhos por cilindro aumentou à medida que se elevou a dose de enxofre de tal forma que o número total de perfilhos foi mais alto na dose de $60 \mathrm{mg} \mathrm{dm}^{-3}$ (Figura 20).

O importante efeito do nitrogênio no perfilhamento da braquiária e outras espécies, sustenta a importância desse nutriente no número de perfilhos nas forrageiras, como já descrito por vários autores como Werner (1986); Corsi (1986); Abreu (1994); Santos (1997) e Manarin (2000).

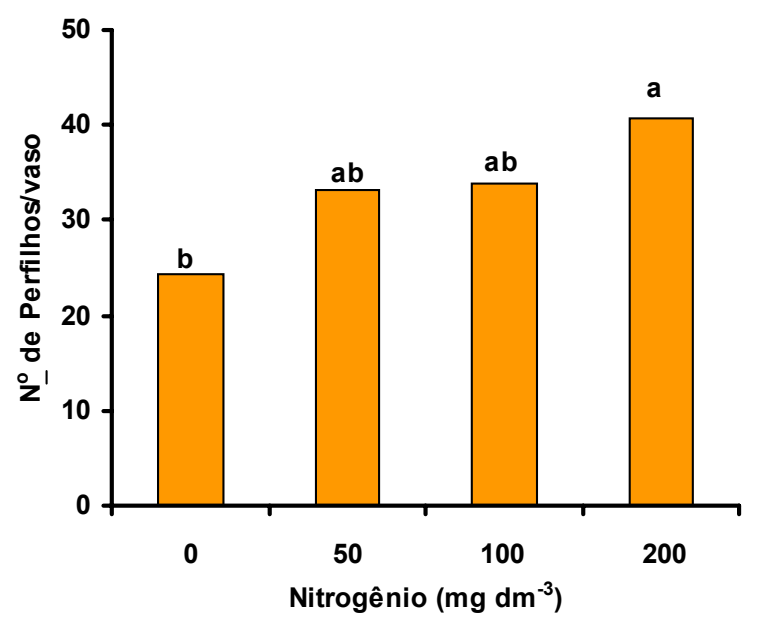

Figura 19 - Número total de perfilhos por cilindro de solo com Brachiaria decumbens, no segundo crescimento, em função das doses de nitrogênio aplicadas no cilindro proveniente da área não recentemente adubada. Letras diferentes indicam diferença significativa ao nível de $1 \%$ de probabilidade pelo teste de Tukey. 


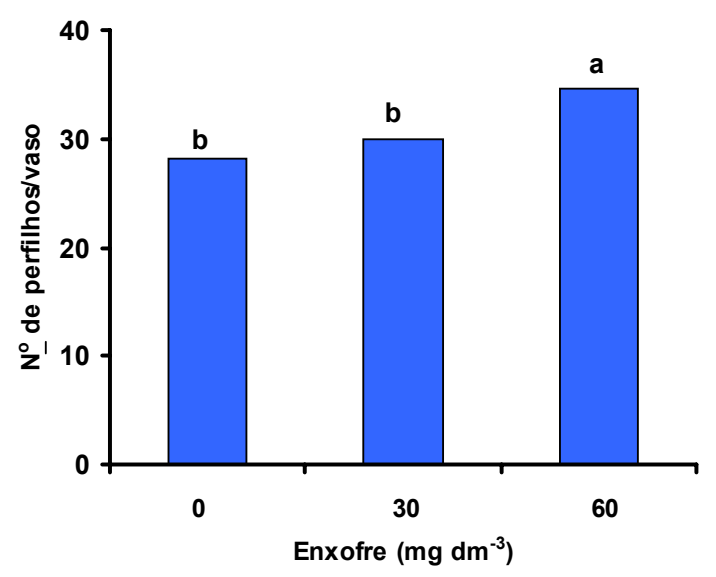

Figura 20 - Número total de perfilhos por cilindro de solo com Brachiaria decumbens, no segundo crescimento, em função das doses de enxofre aplicadas no cilindro proveniente da área não recentemente adubada. Letras diferentes indicam diferença significativa ao nível de $5 \%$ de probabilidade pelo teste de Tukey.

No terceiro crescimento, o número de perfilhos aumentou significativamente da dose de nitrogênio de $100 \mathrm{mg} \mathrm{dm}^{-3}$ para a de $200 \mathrm{mg} \mathrm{dm}^{-3}$, sendo semelhante entre 0; 50 e $100 \mathrm{mg} \mathrm{dm}^{-3}$ (Figura 21). Neste caso, fica evidenciado que a dose máxima de nitrogênio pode não ter sido suficiente para definir o máximo número de perfilhos na braquiária. 


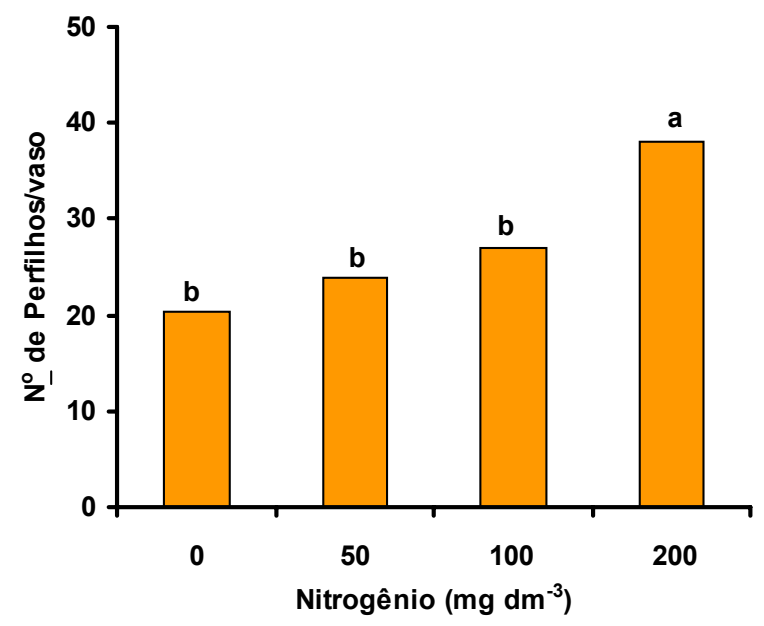

Figura 21 - Número de total perfilhos por cilindro de solo com Brachiaria decumbens, no terceiro crescimento, em função das doses de enxofre aplicadas no cilindro proveniente da área não recentemente adubada. Letras diferentes indicam diferença significativa ao nível de $5 \%$ de probabilidade pelo teste de Tukey.

\subsubsection{Concentração de nitrogênio e de enxofre nas lâminas de folhas recém-expandidas}

A concentração de nitrogênio nas lâminas de folhas recém-expandidas mostrou significância $(P<0,01)$ no primeiro crescimento para doses de nitrogênio, no segundo crescimento para a interação entre doses de nitrogênio e doses de enxofre e no terceiro crescimento tanto para doses de nitrogênio como para as de enxofre.

No material coletado ao final do primeiro crescimento constatou-se que as variações na concentração de nitrogênio nesse tecido vegetal ajustaram-se a uma equação de primeiro grau (Figura 22). Nas lâminas de folhas recémexpandidas da Brachiaria decumbens, a concentração de nitrogênio nesse 
crescimento variou entre 12,2 e $30,0 \mathrm{~g} \mathrm{~kg}^{-1}$, respectivamente, para a mais baixa dose e a dose mais elevada de nitrogênio aplicada.

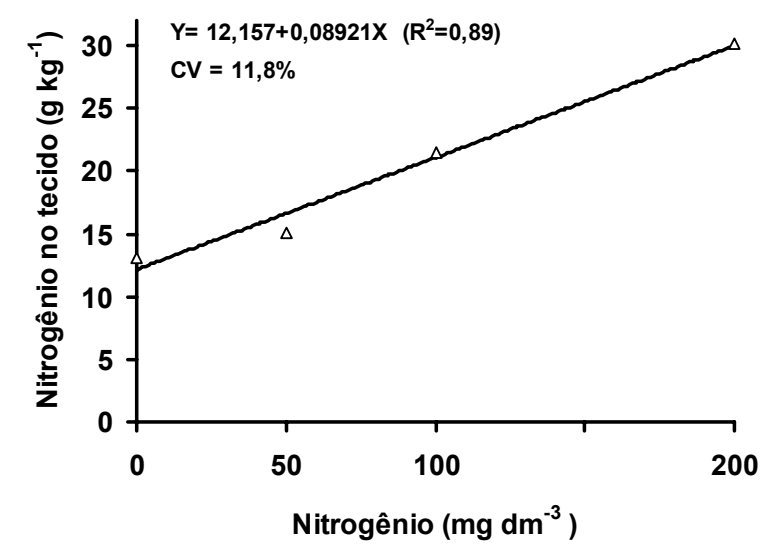

Figura 22 - Concentração de nitrogênio nas lâminas de folhas recémexpandidas da Brachiaria decumbens, no primeiro crescimento, em função das doses de nitrogênio aplicadas no cilindro proveniente da área não recentemente adubada.

Esses resultados demonstram que neste componente da parte aérea a concentração de nitrogênio pode ser ainda mais elevada se forem empregadas doses superiores às avaliadas nestes estudos.

Santos (1997) observou que a concentração de nitrogênio nas lâminas de folhas recém-expandidas da Brachiaria decumbens foi incrementada linearmente com aplicação de doses de nitrogênio, atingindo valores de 12,6 a $27,5 \mathrm{~g} \mathrm{~kg}^{-1}$.

No segundo crescimento, a concentração de nitrogênio nas lâminas de folhas recém-expandidas em função das doses de nitrogênio dentro de cada dose de enxofre, variou significativamente $(P<0,05)$ com as doses de nitrogênio 
dentro de cada dose de enxofre, e os resultados se ajustaram a um modelo linear (Figura 23).

No segundo crescimento do capim-braquiária, a concentração de enxofre nas lâminas de folhas recém-expandidas em função das doses de enxofre dentro de cada dose de nitrogênio foi verificado efeito significativo $(P<0,05)$ para o nitrogênio dentro da dose de enxofre de $30 \mathrm{mg} \mathrm{dm}^{-3}$. Os resultados se ajustaram a um modelo quadrático (Figura 24). Nesse mesmo crescimento, para as doses de enxofre dentro de cada dose de nitrogênio, verificou-se efeito significativo $(P<0,05)$ para o enxofre dentro das doses de nitrogênio de 50; 100 e $200 \mathrm{mg} \mathrm{dm}^{-3}$. Neste caso as doses de enxofre dentro das doses de nitrogênio de 50 e $200 \mathrm{mg} \mathrm{dm}^{-3}$ uma equação do segundo grau representou este efeito e dentro da dose de nitrogênio de $100 \mathrm{mg} \mathrm{dm}^{-3}$ obedeceu a um modelo linear (Figura 25).

A concentração de nitrogênio para as lâminas de folhas recémexpandidas do capim-braquiária no primeiro e no segundo crescimento, foi superior aos valores de nitrogênio de $12 \mathrm{~g} \mathrm{~kg}^{-1}$ encontrados para Brachiaria decumbens e a Brachiaria brizantha por Bredon \& Horrell (1962) e de 12,6 $\mathrm{g} \mathrm{kg}^{-1}$ em Brachiaria decumbens obtidos por Oliveira (1980).

Ferragine \& Monteiro (1999) obtiveram para lâminas de folhas recémexpandidas coletadas nos dois cortes do capim-braquiária submetido a doses de nitrogênio e potássio, modelos quadráticos de regressão. Abreu \& Monteiro (1999) verificaram que as doses de nitrogênio fizeram variar significativamente a concentração de nitrogênio nas lâminas de folhas recém-expandidas. 

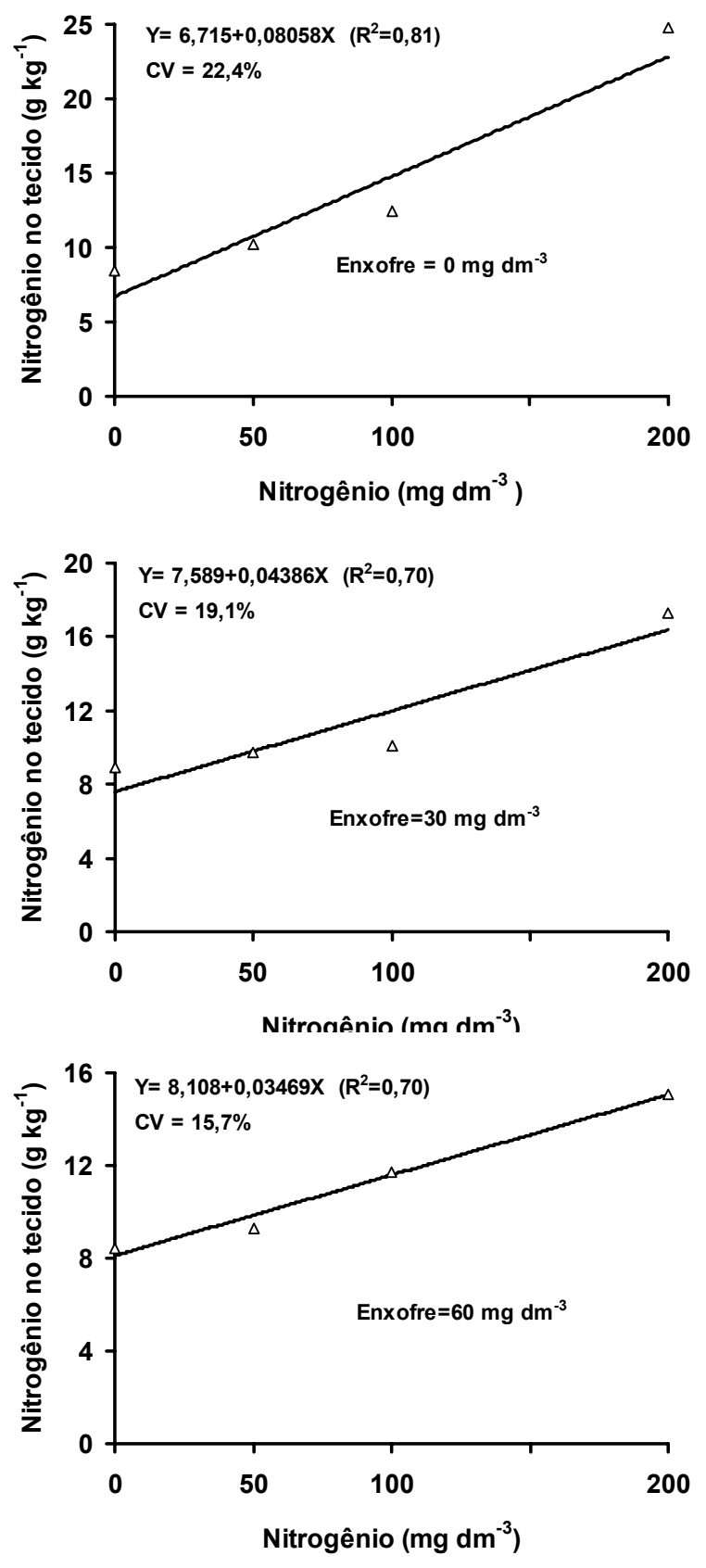

Figura 23 - Concentração de nitrogênio nas lâminas de folhas recém-expandidas da Brachiaria decumbens, no segundo crescimento, em função das doses de nitrogênio dentro de cada dose de enxofre aplicadas no cilindro proveniente da área não recentemente adubada. 


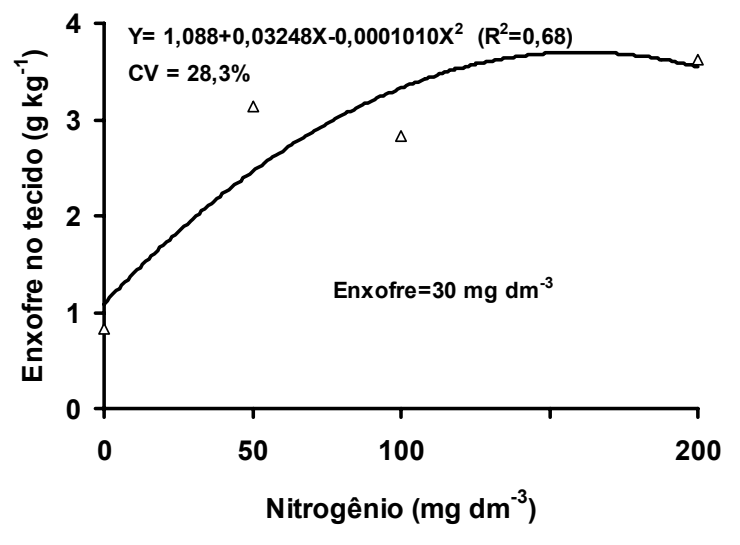

Figura 24 - Concentração de enxofre nas lâminas de folhas recém-expandidas da Brachiaria decumbens, no segundo crescimento, em função das doses de nitrogênio dentro da dose de enxofre de $30 \mathrm{mg} \mathrm{dm}^{-3}$ aplicadas no cilindro proveniente da área não recentemente adubada.

A concentração de nitrogênio nas lâminas de folhas recém-expandidas da Brachiaria decumbens foi superior aquela obtida por Corrêa (1996) no capim Tanzânia-1, Colonião e Vencedor, submetidos a doses de nitrogênio e magnésio em solução nutritiva. 

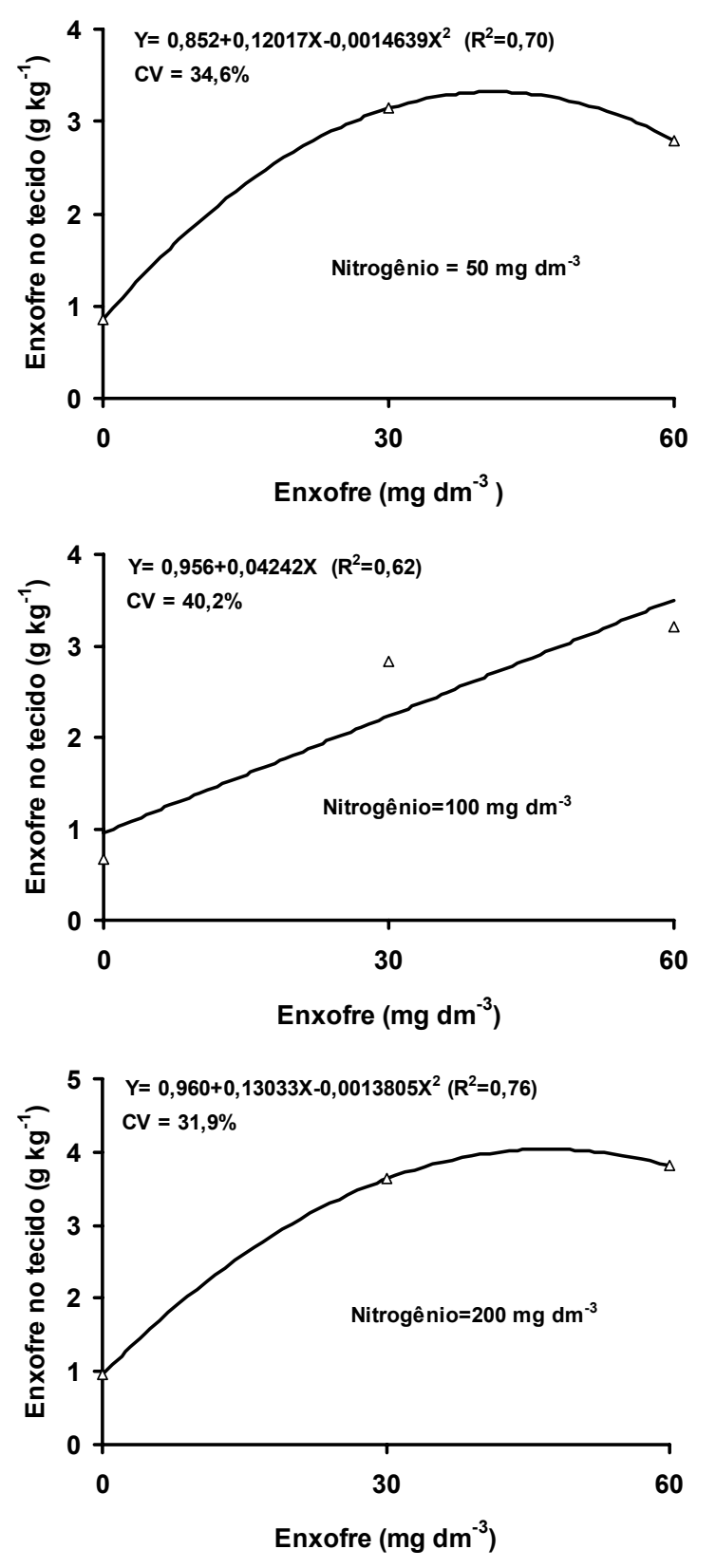

Figura 25 - Concentração de enxofre nas lâminas de folhas recém-expandidas da Brachiaria decumbens, no segundo crescimento, em função das doses de enxofre dentro das doses de nitrogênio de 50; 100 e $200 \mathrm{mg} \mathrm{dm}^{-3}$ aplicadas no cilindro proveniente da área não recentemente adubada. 
No terceiro crescimento, nas lâminas de folhas recém-expandidas a concentração de nitrogênio ajustou-se ao modelo quadrático de regressão. Utilizando-se a equação de regressão pode se verificar que nas lâminas de folhas recém-expandidas a dose de nitrogênio de $129 \mathrm{mg} \mathrm{dm}^{-3}$ foi a que proporcionou a máxima concentração de nitrogênio de $28 \mathrm{~g} \mathrm{~kg}^{-1}$ (Figura 26).

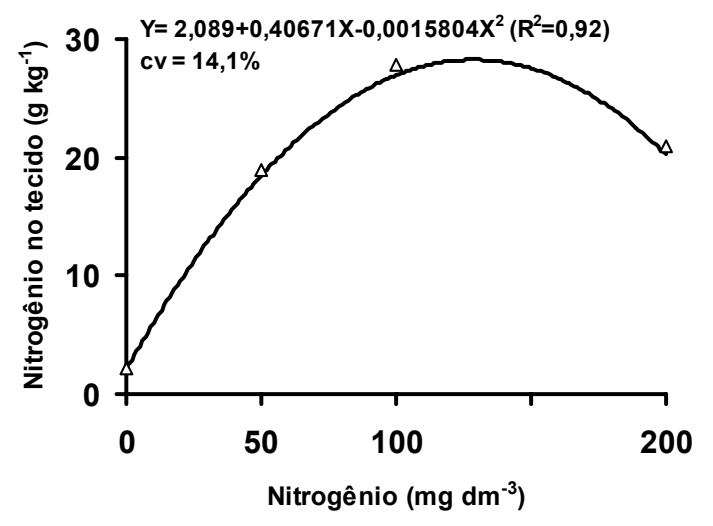

Figura 26 - Concentração de nitrogênio nas lâminas de folhas recémexpandidas da Brachiaria decumbens, no terceiro crescimento, em função das doses de nitrogênio aplicadas no cilindro proveniente da área não recentemente adubada. 
A análise de variância revelou que houve significância $(P<0,01)$ do efeito das doses de enxofre no solo na concentração de enxofre nas lâminas de folhas recém-expandidas. Os resultados apresentados na Figura 27 demonstram ajuste a um modelo de segundo grau para as lâminas de folhas recém-expandidas da planta. A máxima concentração de enxofre nesse componente da forrageira ocorreria além das doses de enxofre utilizadas.

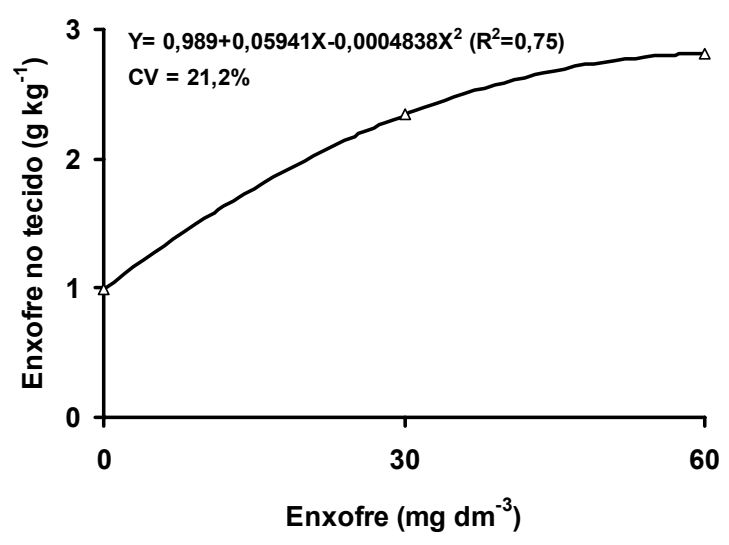

Figura 27 - Concentração de enxofre nas lâminas de folhas recém-expandidas da Brachiaria decumbens, no terceiro crescimento, em função das doses de enxofre aplicadas no cilindro proveniente da área não recentemente adubada. 


\subsubsection{Experimento com forrageira proveniente de área recentemente adubada}

\subsubsection{Produção de matéria seca da parte aérea}

A produção de matéria seca da parte aérea da Brachiaria decumbens retirada da área recentemente adubada apresentou significância $(P<0,01)$ para a interação entre doses de nitrogênio e doses de enxofre, no primeiro crescimento.

O desdobramento da interação entre as doses de nitrogênio e as doses de enxofre revelou um efeito significativo $(P<0,01)$ das doses de nitrogênio dentro das doses de enxofre. Esses resultados, mostraram um ajuste a modelo quadrático das doses de nitrogênio dentro de cada dose de enxofre, no primeiro crescimento (Figura 28). Verifica-se na Figura 28 que o nitrogênio fornecido foi mais eficientemente convertido em massa pela forrageira nas doses nas doses de enxofre de 30 e $60 \mathrm{mg} \mathrm{dm}{ }^{-3}$. Com isso pode-se constatar que o fornecimento de nitrogênio causa maior aumento da produção de matéria seca quando não houver limitação severa de enxofre, o que concorda com Werner \& Monteiro (1988), os quais relataram que as pastagens com deficiência de nitrogênio respondem muito pouco ao enxofre. Por outro lado, em alta disponibilidade de nitrogênio a exigência por enxofre é maior, uma vez que este nutriente também é importante no metabolismo do nitrogênio e na síntese de proteína. 

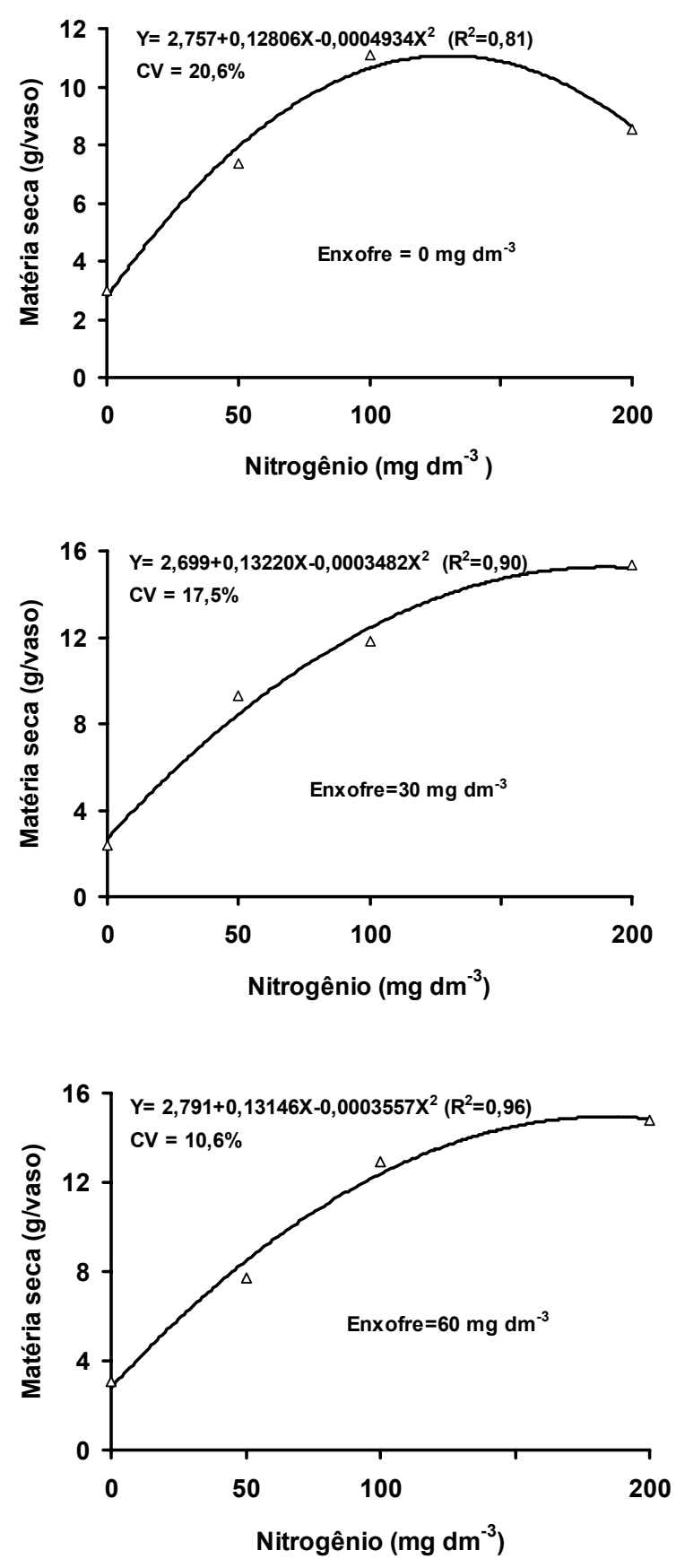

Figura 28 - Produção de matéria seca da parte aérea da Brachiaria decumbens, no primeiro crescimento, em função das doses de nitrogênio dentro de cada dose de enxofre aplicadas no cilindro proveniente da área recentemente adubada. 
No desdobramento da interação para o estudo de enxofre dentro de doses de nitrogênio, em termos da produção da parte aérea, verificou-se efeito significativo $(P<0,01)$ do enxofre dentro das doses de nitrogênio de 50 e 200 $\mathrm{mg} \mathrm{dm}^{-3}$. Esse efeito foi representado por equações do segundo grau. A máxima produção de matéria seca na parte aérea ocorreu em $32 \mathrm{mg} \mathrm{dm}^{-3}$ de enxofre quando a dose de nitrogênio foi de $50 \mathrm{mg} \mathrm{dm}^{-3}$ e $43 \mathrm{mg} \mathrm{dm}^{-3}$ de enxofre quando o nitrogênio foi suprido em $200 \mathrm{mg} \mathrm{dm}^{-3}$ (Figuras 29 e 30). Nas doses de nitrogênio de 0 e $100 \mathrm{mg} \mathrm{dm}^{-3}$ não se constatou significância $(P>0,05)$ para as doses de enxofre.

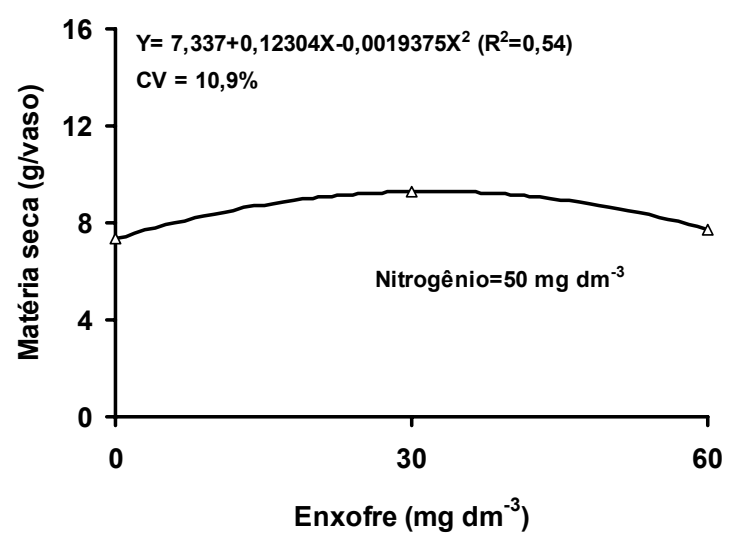

Figura 29 - Produção de matéria seca da parte aérea da Brachiaria decumbens, no primeiro crescimento, em função das doses de enxofre dentro da dose $50 \mathrm{mg} \mathrm{dm}^{-3}$ de nitrogênio aplicadas no cilindro proveniente da área recentemente adubada. 


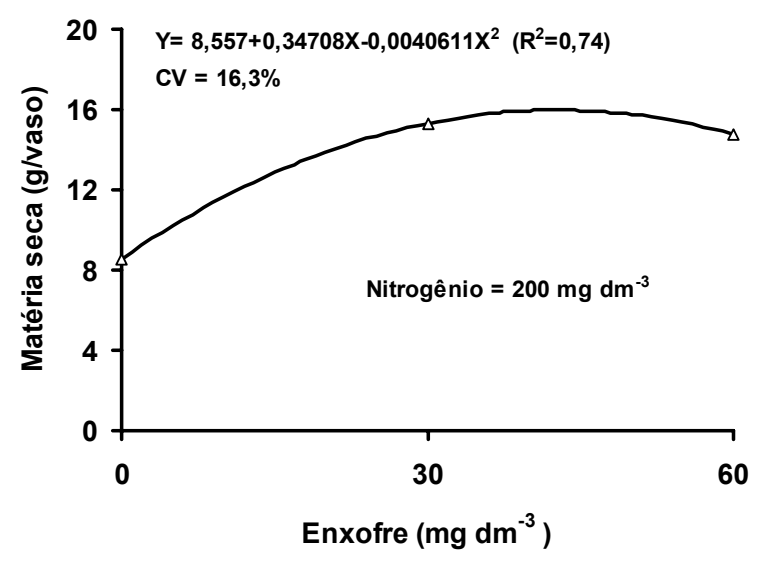

Figura 30 - Produção de matéria seca da parte aérea da Brachiaria decumbens, no primeiro crescimento, em função das doses de enxofre dentro da dose $200 \mathrm{mg} \mathrm{dm}^{-3}$ de nitrogênio aplicadas no cilindro proveniente da área recentemente adubada.

As doses de nitrogênio influenciaram significativamente $(P<0,01)$ a produção de matéria seca da parte aérea no segundo crescimento da Brachiaria decumbens, ajustando-se a um modelo quadrático (Figura 31).

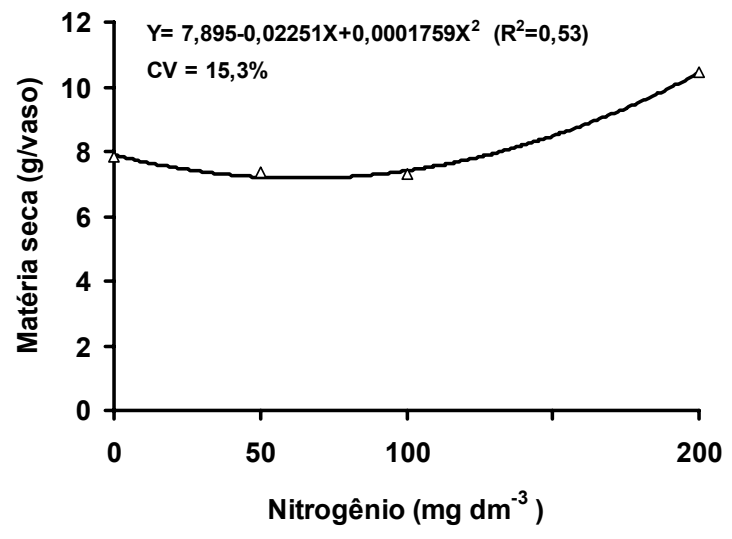

Figura 31 - Produção de matéria seca da parte aérea da Brachiaria decumbens, no segundo crescimento, em função das doses de nitrogênio aplicadas no cilindro proveniente da área recentemente adubada. 

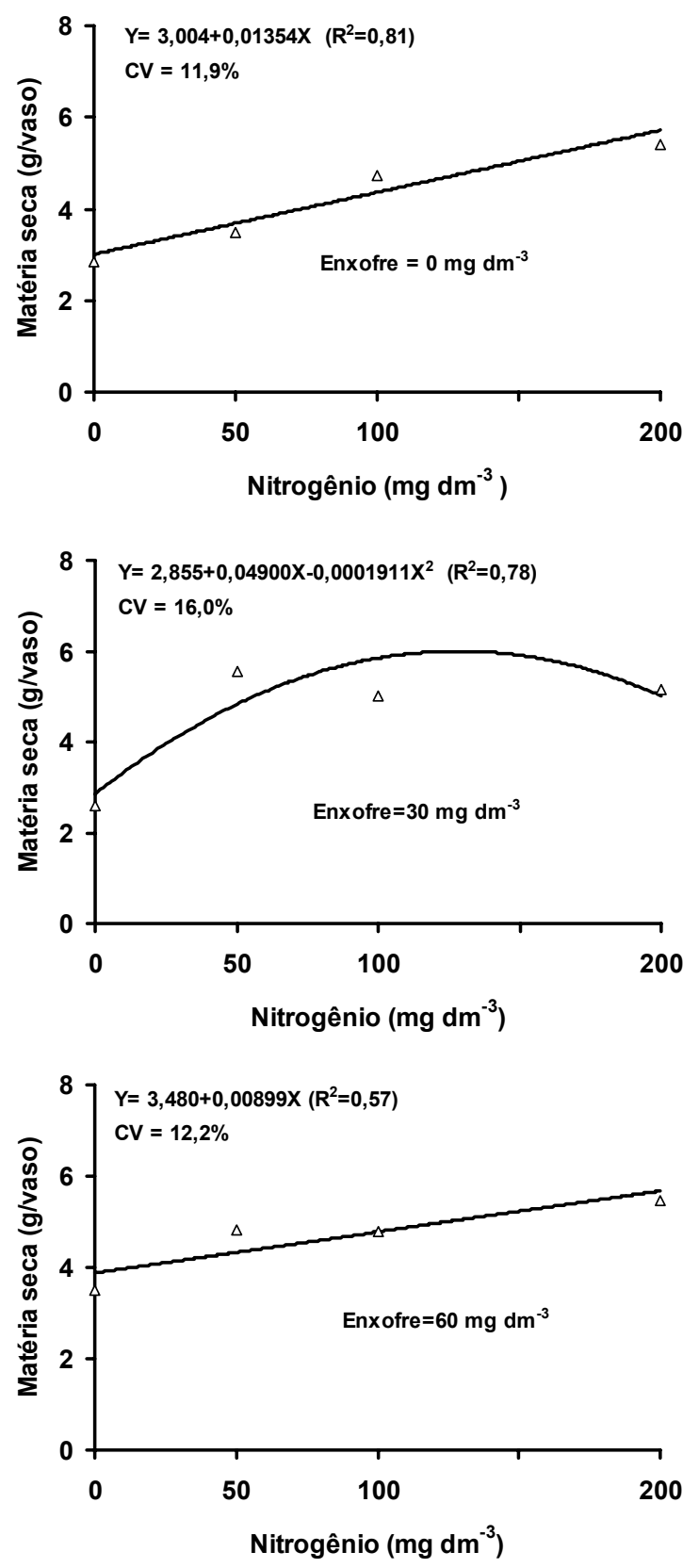

Figura 32 - Produção de matéria seca da parte aérea da Brachiaria decumbens, no terceiro crescimento, em função das doses de nitrogênio dentro de cada dose de enxofre aplicadas no cilindro proveniente da área recentemente adubada. 
No terceiro crescimento, a análise de variância da produção de matéria seca da parte aérea do capim mostrou significância para a interação entre as doses de nitrogênio e doses de enxofre $(P<0,01)$.

$\mathrm{Na}$ Figura 32 as equações mostram os ajustes a modelo linear para a produção de matéria seca da parte aérea da Brachiaria decumbens, em função das doses de nitrogênio dentro das doses de enxofre de 0 e $60 \mathrm{mg} \mathrm{dm}^{-3}$ e a modelo quadrático para doses de nitrogênio dentro da dose de enxofre de 30 $\mathrm{mg} \mathrm{dm}{ }^{-3}$.

A produção de matéria seca da parte aérea do capim, no terceiro crescimento, teve efeito significativo $(\mathrm{P}<0,01)$ das doses de enxofre dentro da dose de nitrogênio de $50 \mathrm{mg} \mathrm{dm}$ e esse efeito foi representado por uma equação de segundo grau (Figura 33).O ponto de máxima produção de matéria seca da parte aérea ocorreu com a aplicação de enxofre de $37 \mathrm{mg} \mathrm{dm}^{-3}$.

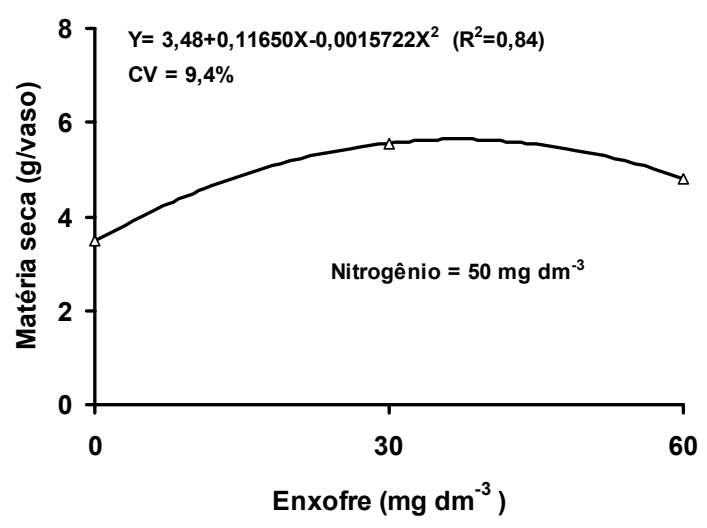

Figura 33 - Produção de matéria seca da parte aérea da Brachiaria decumbens, no terceiro crescimento, em função das doses de enxofre dentro da dose $50 \mathrm{mg} \mathrm{dm}^{-3}$ de nitrogênio aplicadas no cilindro proveniente da área recentemente adubada. 


\subsubsection{Estimativa do teor de clorofila através do valor SPAD}

Os resultados das leituras SPAD na lâmina foliar da Brachiaria decumbens proveniente da área adubada em função das doses de nitrogênio e de enxofre, por ocasião do primeiro crescimento, ocorreu significância para a interação entre as doses de nitrogênio e as doses de enxofre utilizadas.

Em cada uma das três doses de enxofre, o efeito das doses de nitrogênio promoveu um ajuste a um modelo quadrático quando o enxofre não foi fornecido na adubação e para modelos lineares nas doses 30 e $60 \mathrm{mg} \mathrm{dm}^{-3} \mathrm{de}$ enxofre. Essa linearidade demonstra que haveria resposta a doses mais elevadas de nitrogênio dentro das doses de enxofre 30 e $60 \mathrm{mg} \mathrm{dm}^{-3}$ (Figura $34)$.

No estudo das doses de enxofre dentro de cada dose de nitrogênio constatou-se, no primeiro crescimento, significância $(P<0,01)$ para enxofre dentro de nitrogênio 0 e $200 \mathrm{mg} \mathrm{dm}^{-3}(P<0,01)$. Uma equação do primeiro grau representou o efeito quando não se adubou com o nitrogênio (Figura 35) e uma equação do segundo grau quando aplicou-se $200 \mathrm{mg} \mathrm{dm}^{-3}$ de nitrogênio (Figura 36). O ponto de máximo valor SPAD na lâmina foliar ocorreria em doses de enxofre mais elevada que às aplicadas, quando não se supriu o nitrogênio. Por outro lado, com a aplicação de nitrogênio de $200 \mathrm{mg} \mathrm{dm}^{-3}$ o ponto máximo do valor SPAD ocorreu com o suprimento de enxofre em $45 \mathrm{mg} \mathrm{dm}^{-3}$.

Esses resultados confirmam a importância do enxofre na formação das moléculas de clorofila, fato relatado por muitos autores, entre os quais Malavolta (1974) e Marschner (1995).

O nível crítico de nitrogênio nas lâminas recém-expandidas determinado aos 28 dias de desenvolvimento no crescimento final do capim-Marandu foi de 23,2 $\mathrm{g} \mathrm{kg}^{-1}$ e o valor SPAD associado a esse nível foi de 39 (Abreu \& Monteiro, 1999). 

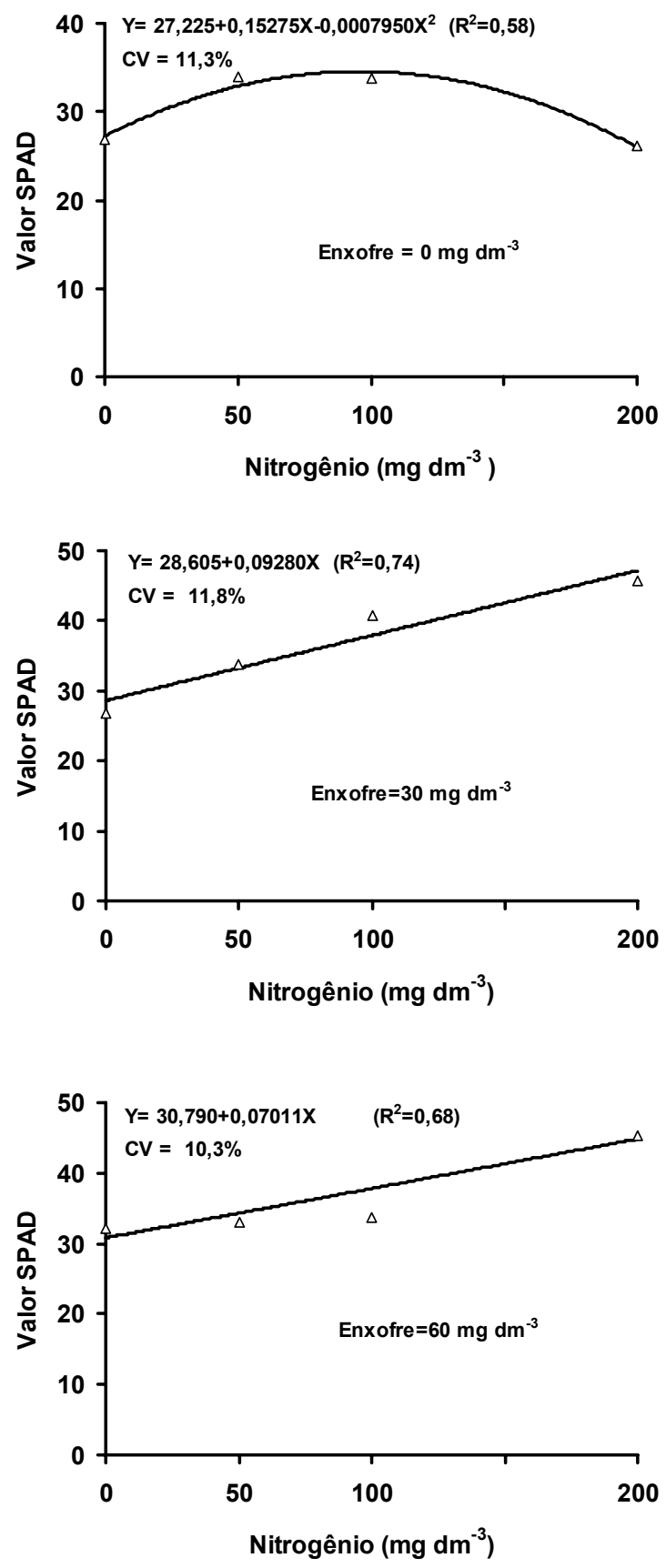

Figura 34 - Valor SPAD na Brachiaria decumbens, no primeiro crescimento, em função das doses de nitrogênio dentro de cada dose de enxofre aplicadas no cilindro proveniente da área recentemente adubada. 


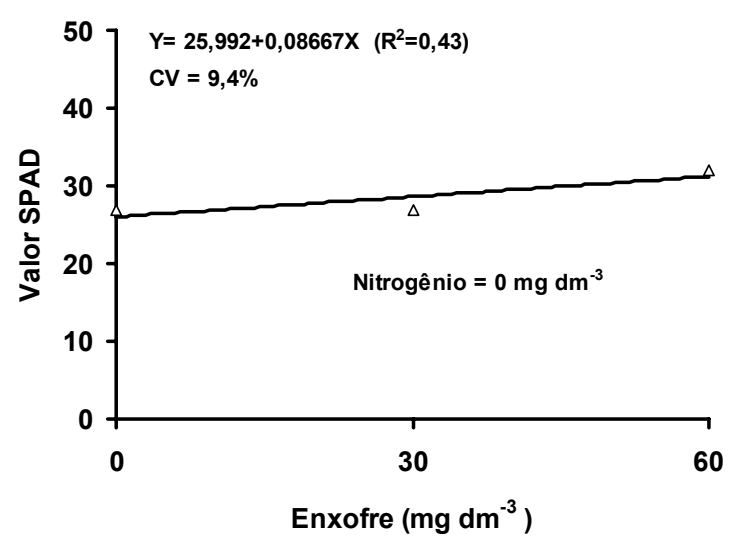

Figura 35 - Valor SPAD na Brachiaria decumbens, no primeiro crescimento, em função das doses de enxofre dentro da não aplicação de nitrogênio no cilindro proveniente da área recentemente adubada.

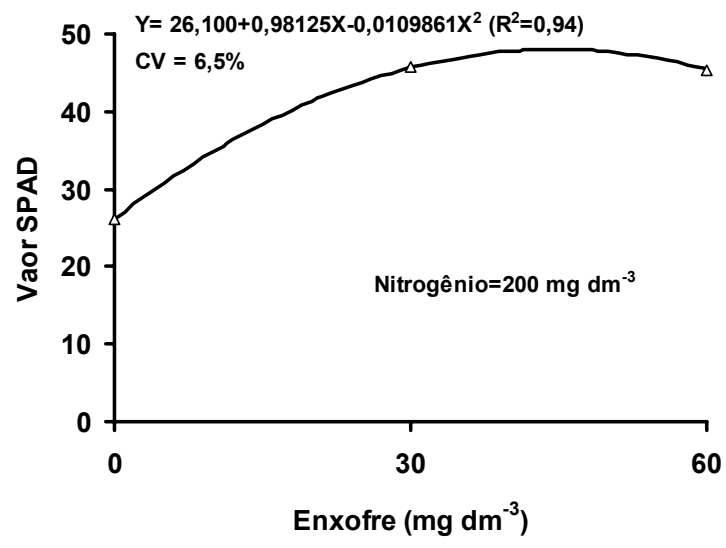

Figura 36 - Valor SPAD na Brachiaria decumbens, no primeiro crescimento, em função das doses de enxofre dentro da dose $200 \mathrm{mg} \mathrm{dm}^{-3}$ de nitrogênio aplicadas no cilindro proveniente da área recentemente adubada. 
No segundo crescimento 0 valor SPAD na forrageira mostrou significância para as doses de nitrogênio dentro da dose de enxofre de 30 $\mathrm{mg} \mathrm{dm}^{-3}$ (Figura 37). O valor SPAD em relação as doses de nitrogênio dentro da dose de enxofre de $30 \mathrm{mg} \mathrm{dm}^{-3}$ ajustou-se a um modelo linear, evidenciando que a planta continuaria respondendo, em valor SPAD, a doses de nitrogênio mais elevadas que as utilizadas.

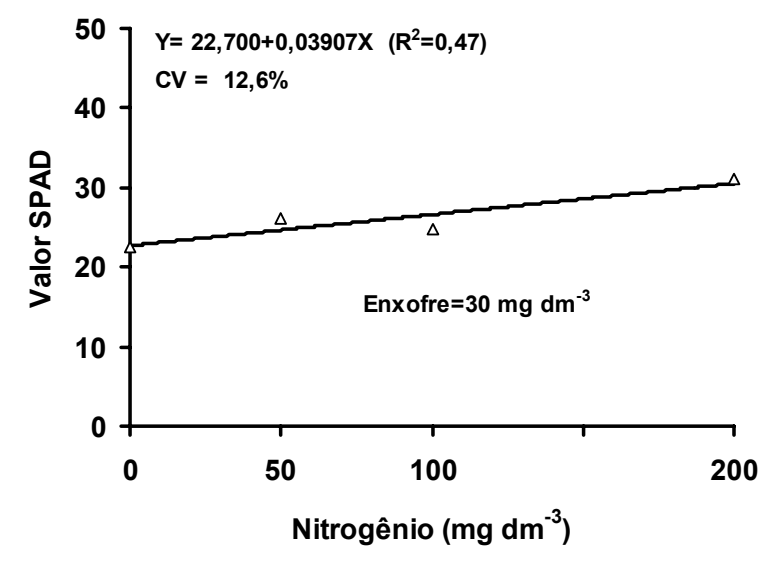

Figura 37 - Valor SPAD na Brachiaria decumbens, no segundo crescimento, em função das doses de nitrogênio dentro da dose $30 \mathrm{mg} \mathrm{dm}^{-3}$ de enxofre aplicadas no cilindro proveniente da área recentemente adubada.

No terceiro crescimento do capim os valores SPAD apresentaram ajuste a modelo quadrático de regressão em função das doses de nitrogênio, na média das três doses de enxofre. A análise desta equação mostra que o teor de clorofila, expresso em valor SPAD, variou entre 20,5 e 37,0 , respectivamente para a condição de não aplicação de nitrogênio e a dose de nitrogênio de 140 $\mathrm{mg} \mathrm{dm}^{-3}$. 


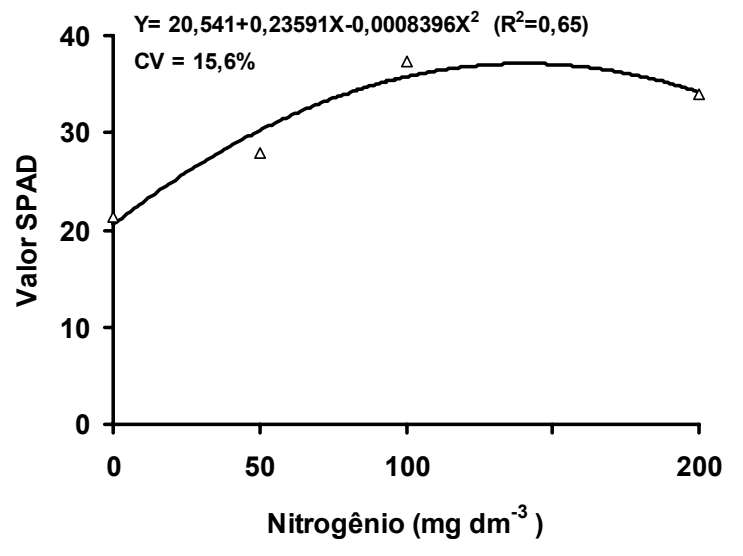

Figura 38 - Valor SPAD na Brachiaria decumbens, no terceiro crescimento, em função das doses de nitrogênio aplicadas no cilindro proveniente da área recentemente adubada.

\subsubsection{3 Área foliar}

No experimento em que se cultivou a Brachiaria decumbens em cilindros provenientes da área recentemente adubada verificou-se, no primeiro crescimento, interação significativa $(P<0,01)$ entre as doses de nitrogênio e as de enxofre para área foliar total. No desdobramento dessa interação pode-se verificar que ocorreu ajuste a modelos quadráticos para as doses de nitrogênio dentro de cada dose de enxofre. Quando se utilizou a dose de enxofre de 60 $\mathrm{mg} \mathrm{dm}^{-3}$ atingiu-se a máxima área foliar em doses mais baixas de nitrogênio em relação à dose de enxofre de $30 \mathrm{mg} \mathrm{dm}^{-3}$ (Figura 39).

Pode-se notar, na Figura 40, que quando o nitrogênio fornecido foi de $200 \mathrm{mg} \mathrm{dm}^{-3}$ a máxima área foliar ocorreria em dose de enxofre mais elevada que as utilizadas no presente experimento.

$\mathrm{Na}$ análise de variância da área foliar total no segundo crescimento observou-se que não foi significativa $(P>0,05)$ a interação nitrogênio e potássio, além de não ter ocorrido efeito das doses de nitrogênio e enxofre. 

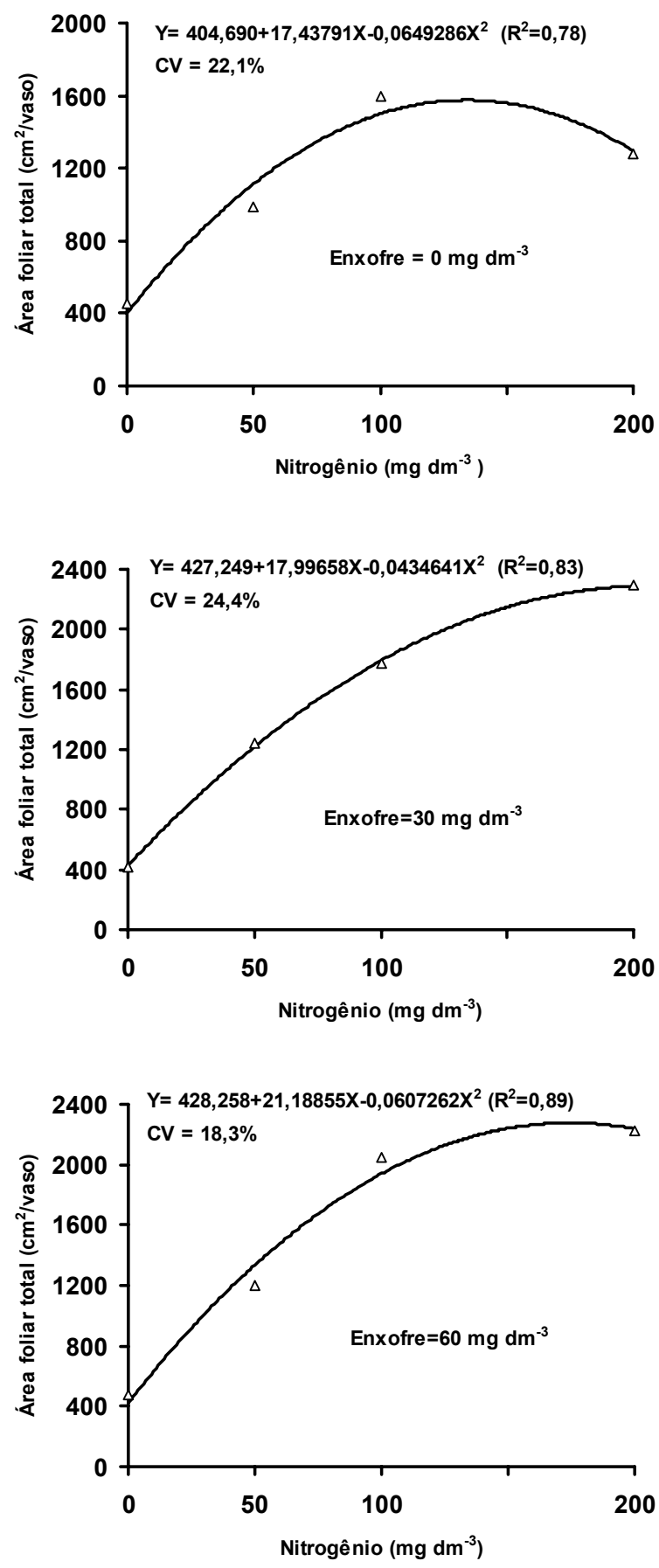

Figura 39 - Área foliar total da Brachiaria decumbens, no primeiro crescimento, em função da dose de nitrogênio dentro de cada dose de enxofre aplicadas no cilindro proveniente da área recentemente adubada. 


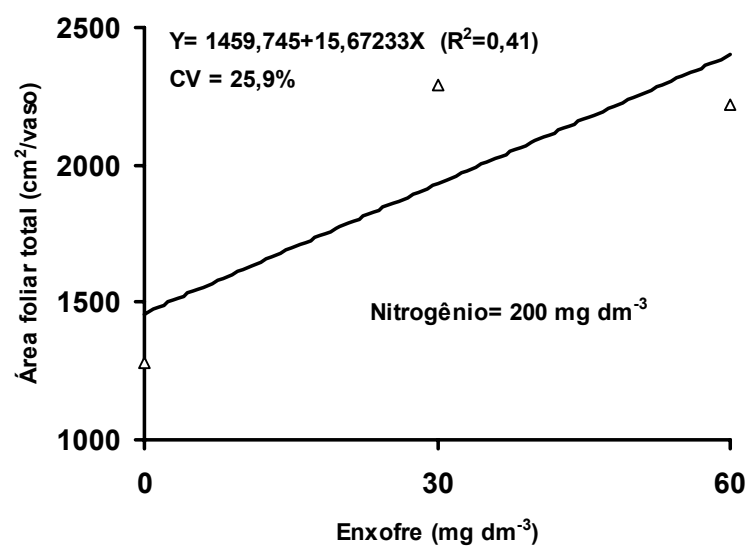

Figura 40 - Área foliar total da Brachiaria decumbens, no primeiro crescimento, em função da dose de enxofre dentro da dose $200 \mathrm{mg} \mathrm{dm}^{-3}$ de nitrogênio aplicadas no cilindro proveniente da área recentemente adubada.

O efeito de duas doses de nitrogênio na taxa de alongamento foliar em festuca foram estudados por Volenec \& Nelson (1983) os quais encontraram que a taxa de alongamento das folhas foi $89 \%$ maior com alta dose de nitrogênio. Neste caso, o tamanho final das células da epiderme não sofreu influência do nitrogênio, porém o número de células epidermiais produzidas por fila por dia aumentou $90 \%$ com altas doses de nitrogênio, sugerindo um maior efeito do nutriente na divisão celular. A disponibilidade de nitrogênio tem pronunciado efeito na taxa de alongamento foliar, podendo resultar em valores três a quatro vezes menores num alto nível de deficiência, quando comparado a um nível não limitante (Gastal et al., 1992).

A taxa de expansão foliar do capim-Guiné e da capim-setária submetidas a doses de nitrogênio estudada por Pinto et al. (1994) apresentou folhas maiores no capim-Guiné em relação ao capim-Setária. Manarin (2000) 
também verificou efeitos significativos de doses de nitrogênio na área foliar do capim-Mombaça.

O efeito do nitrogênio na taxa de alongamento foliar, decorre do maior acúmulo deste nutriente na zona de alongamento da folha, mais precisamente na região de divisão celular (Gastal \& Nelson, 1994). Os autores ainda verificaram alta correlação entre a quantidade de nitrogênio contido nessa região e a taxa de expansão foliar.

Para o terceiro crescimento, verificou-se interação significativa $(P<0,01)$ entre as doses de nitrogênio e as de enxofre para a área foliar total. No material colhido no terceiro crescimento, foi verificada significância $(P<0,01)$ para as doses de enxofre dentro das doses de nitrogênio de 50, 100 e $200 \mathrm{mg} \mathrm{dm}^{-3}$, sendo a resposta ajustada a modelo quadrático (Figura 41). Os pontos de máxima área foliar total nas doses de enxofre dentro das doses de 50, $100 \mathrm{e}$ $200 \mathrm{mg} \mathrm{dm}^{-3}$ foram alcançados com doses de enxofre de 30,40 e $40 \mathrm{mg} \mathrm{dm}^{-3}$, respectivamente. Apesar de o ponto de máxima área foliar total do capim ter sido alcançado com a mesma dose de enxofre dentro das doses de nitrogênio de 100 e $200 \mathrm{mg} \mathrm{dm}^{-3}$, a área foliar total na mais alta dose de nitrogênio foi maior em relação a dose de nitrogênio de $100 \mathrm{mg} \mathrm{dm}^{-3}$. 

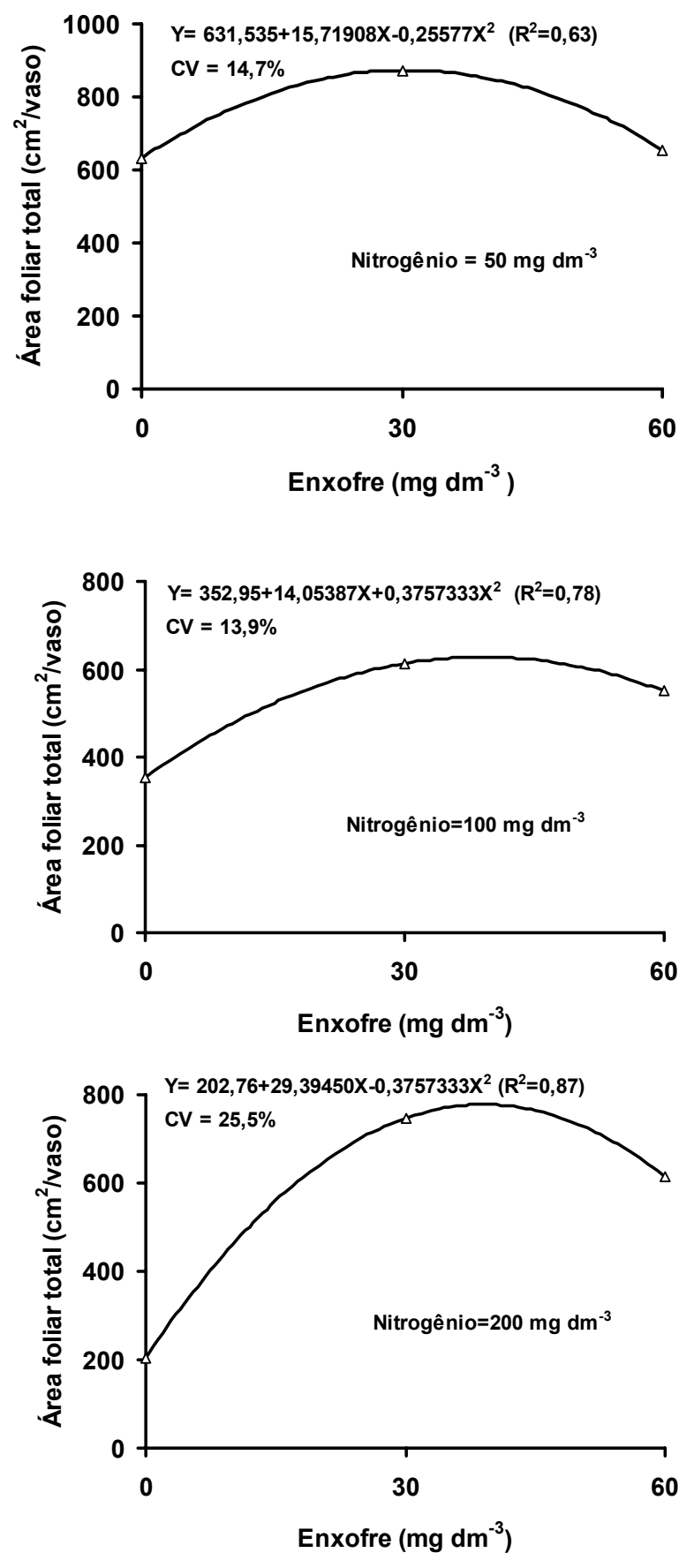

Figura 41 - Área foliar total da Brachiaria decumbens, no terceiro crescimento, em função das doses de nitrogênio dentro de cada dose de enxofre aplicadas no cilindro proveniente da área recentemente adubada. 


\subsubsection{Número de perfilhos}

O número total de perfilhos, no primeiro crescimento da Brachiaria decumbens submetida as doses de nitrogênio variou significativamente do não suprimento desse nutriente para as doses 100 e $200 \mathrm{mg} \mathrm{dm}^{-3}$. Isso está de acordo com Werner (1986), Hoffmann (1992), Santos (1997) e Nabinger \& Medeiros (1997), que apontaram ter que o nitrogênio efeitos positivos no número de perfilhos das forrageiras. Quando a dose de nitrogênio foi incrementada de 50 para 100 e para $200 \mathrm{mg} \mathrm{dm}^{-3}$ o número total de perfilhos não sofreu variação significativa (Figura 42). Não se verificou significância $(P>0,05)$ das doses de enxofre no número total de perfilhos para ambos os crescimentos.

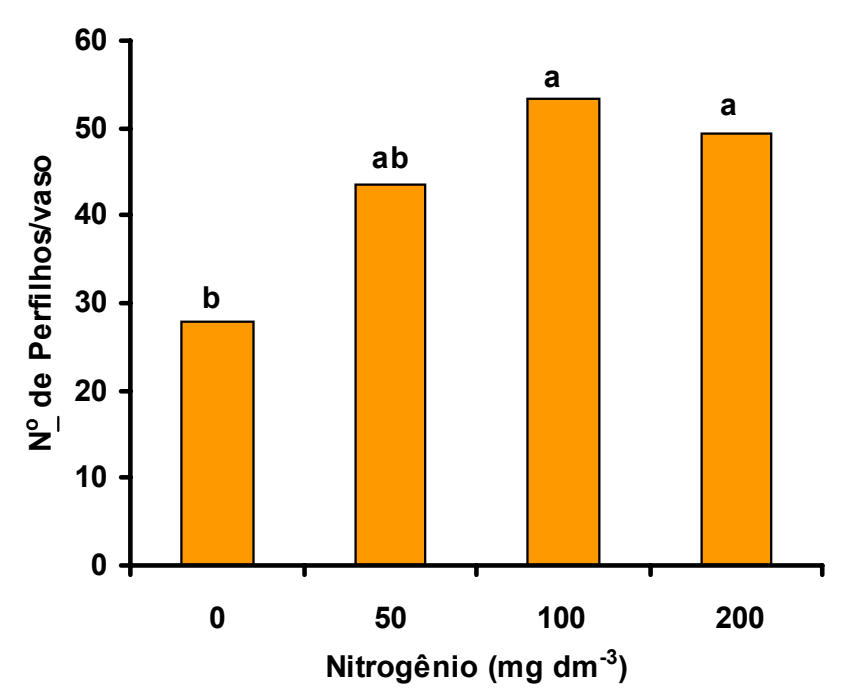

Figura 42 - Número total de perfilhos por cilindro de solo com Brachiaria decumbens, no primeiro crescimento, em função das doses de nitrogênio aplicadas no cilindro proveniente da área recentemente adubada. Letras diferentes indicam diferença significativa ao nível de 1\% de probabilidade pelo teste de Tukey. 
O número total de perfilhos por cilindro, no segundo crescimento da Brachiaria decumbens foi mais elevado na dose de nitrogênio de $200 \mathrm{mg} \mathrm{dm}^{-3}$ que na não aplicação do nitrogênio. Não ocorreu variação significativa $(P<0,05)$ entre as doses de $50 ; 100$ e $200 \mathrm{mg} \mathrm{dm}^{-3}$ para essa variável (Figura 43). Santos et. al. (1995) constataram que o perfilhamento do capim-Vencedor submetido a doses de nitrogênio diferiu acentuada e significativamente entre as condições de alto e de baixo suprimento de nitrogênio, para o primeiro e segundo crescimentos.

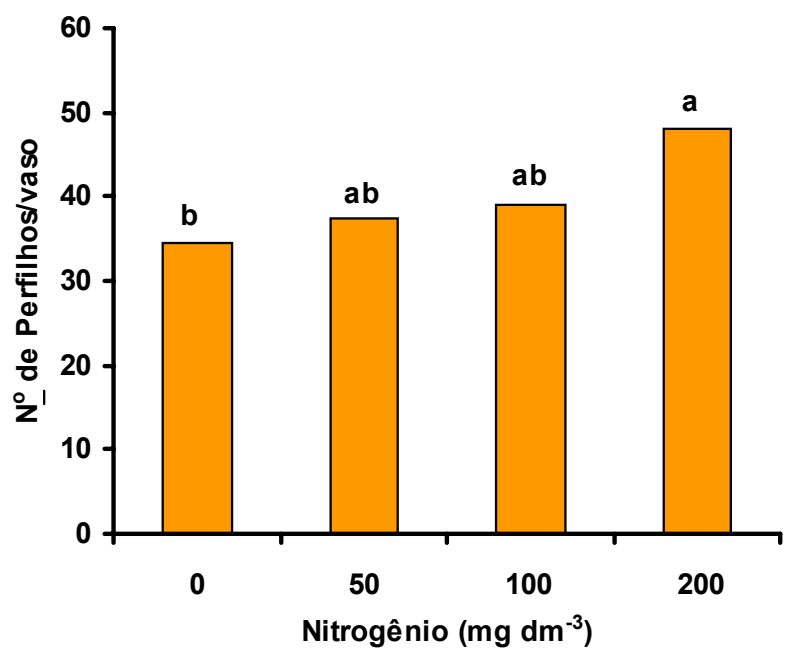

Figura 43 - Número total de perfilhos por cilindro de solo com Brachiaria decumbens, no segundo crescimento, em função das doses de nitrogênio aplicadas no cilindro proveniente da área recentemente adubada. Letras diferentes indicam diferença significativa ao nível de $5 \%$ de probabilidade pelo teste de Tukey. 
$\mathrm{Na}$ avaliação do número total de perfilhos no terceiro crescimento, mediante o emprego das doses de nitrogênio no solo, foi constatado que o número de perfilhos não variou significativamente $(P<0,05)$ da dose de nitrogênio 100 para a dose $200 \mathrm{mg} \mathrm{dm}^{-3}$, mas foi significativamente mais baixo na condição sem adubação nitrogenada em relação às duas mais elevadas doses de nitrogênio (Figura 44).

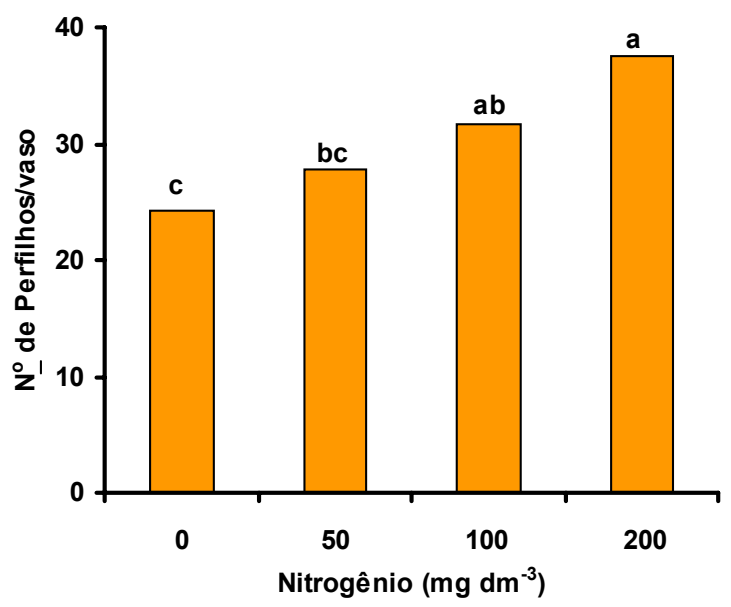

Figura 44 - Número total de perfilhos por cilindro de solo com Brachiaria decumbens, no terceiro crescimento, em função das doses de nitrogênio aplicadas no cilindro proveniente da área recentemente adubada. Letras diferentes indicam diferença significativa ao nível de $5 \%$ de probabilidade pelo teste de Tukey. 


\subsubsection{Concentração de nitrogênio e de enxofre nas lâminas de folhas recém-expandidas}

A concentração de nitrogênio nas lâminas de folhas recém-expandidas mostrou significância $(P<0,01)$ no primeiro crescimento para doses de nitrogênio, no terceiro crescimento para as doses de nitrogênio e de enxofre, mas no segundo crescimento não houve efeito significativo $(P>0,05)$ das doses de nitrogênio e enxofre e nem para interação entre estes nutrientes. Para a concentração de enxofre nessas lâminas foliares, no primeiro crescimento, não verificou-se efeito significativo $(P>0,05)$ das doses de nitrogênio e de enxofre, no segundo crescimento houve efeito significativo $(P<0,01)$ para a interação entre doses de nitrogênio e doses de enxofre e no terceiro crescimento essa significância $(P<0,05)$ ocorreu para as doses de enxofre.

No material coletado ao final do primeiro crescimento constatou-se que as variações na concentração de nitrogênio nesse tecido vegetal ajustaram-se a uma equação de primeiro grau (Figura 45). Nas lâminas de folhas recémexpandidas da Brachiaria decumbens, a concentração de nitrogênio nesse tecido e nesse crescimento variou entre 11,5 e $18,0 \mathrm{~g} \mathrm{~kg}^{-1}$, respectivamente, para a não aplicação e para a dose mais elevada de nitrogênio no experimento.

Santos (1997) observou que a concentração de nitrogênio nas lâminas de folhas recém-expandidas do capim-braquiária foi incrementada linearmente com aplicação de doses de nitrogênio, atingindo valores de 12,6 a $27,5 \mathrm{~g} \mathrm{~kg}^{-1}$. Resultados semelhantes foram verificados por Bredon \& Horrell (1962) para a Brachiaria decumbens que foi de $12,6 \mathrm{~g} \mathrm{~kg}^{-1}$ para a parte aérea total da planta. Pode-se observar que na mais elevada dose de nitrogênio utilizada a concentração de nitrogênio nas lâminas de folhas recém-expandidas foi bem mais baixa que a alcançada por Santos (1997). 


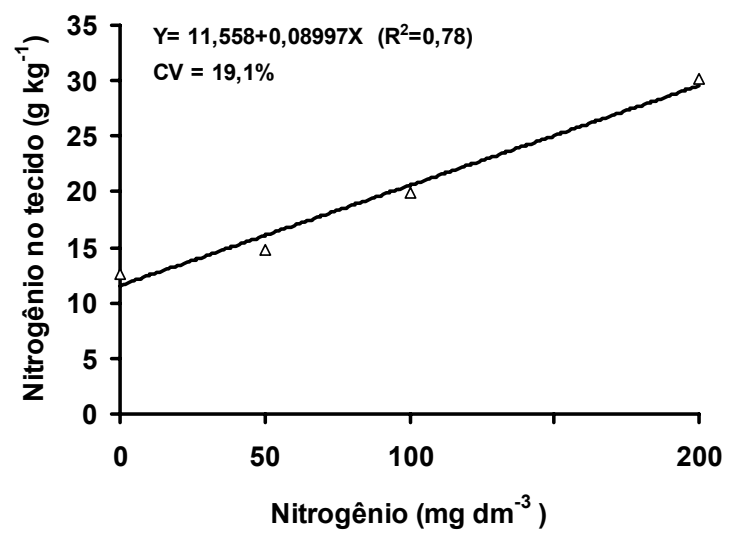

Figura 45 - Concentração de nitrogênio nas lâminas de folhas recém-expandida da Brachiaria decumbens, no primeiro crescimento, em função das doses de nitrogênio aplicadas no cilindro proveniente da área recentemente adubada.

A concentração de enxofre nas lâminas de folhas recém-expandida, no segundo crescimento, variou significativamente $(P<0,05)$ para o nitrogênio dentro das dose de enxofre de 30 e $60 \mathrm{mg} \mathrm{dm}^{-3}$, nas quais os resultados se ajustaram a modelos quadráticos (Figura 46).

No segundo crescimento da Brachiaria decumbens, foi verificado efeito significativo $(P<0,01)$ na concentração de enxofre nas lâminas de folhas recémexpandidas em função das doses de enxofre dentro das doses de nitrogênio de $0 ; 100$ e $200 \mathrm{mg} \mathrm{dm}^{-3}$. Esses resultados se ajustaram a modelos lineares (Figura 47). 

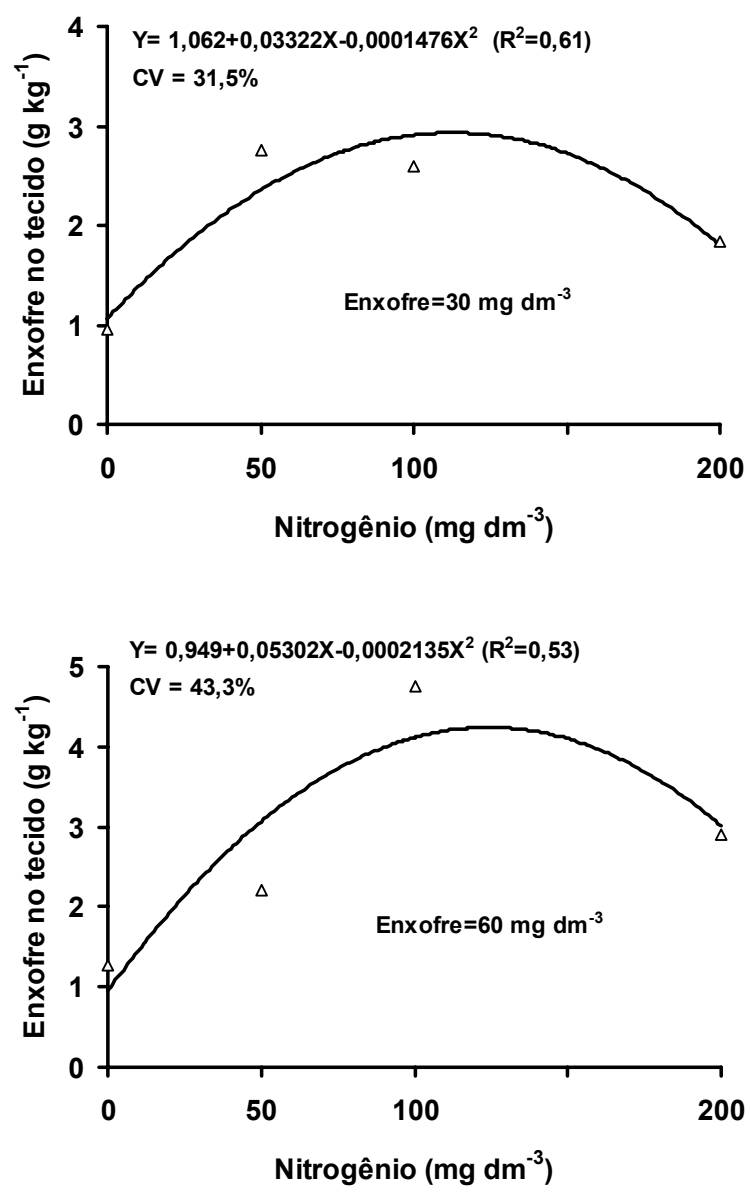

Figura 46 - Concentração de enxofre nas lâminas de folhas recém-expandida da Brachiaria decumbens, no segundo crescimento, em função das doses de nitrogênio dentro das doses de enxofre aplicadas no cilindro proveniente da área recentemente adubada. 

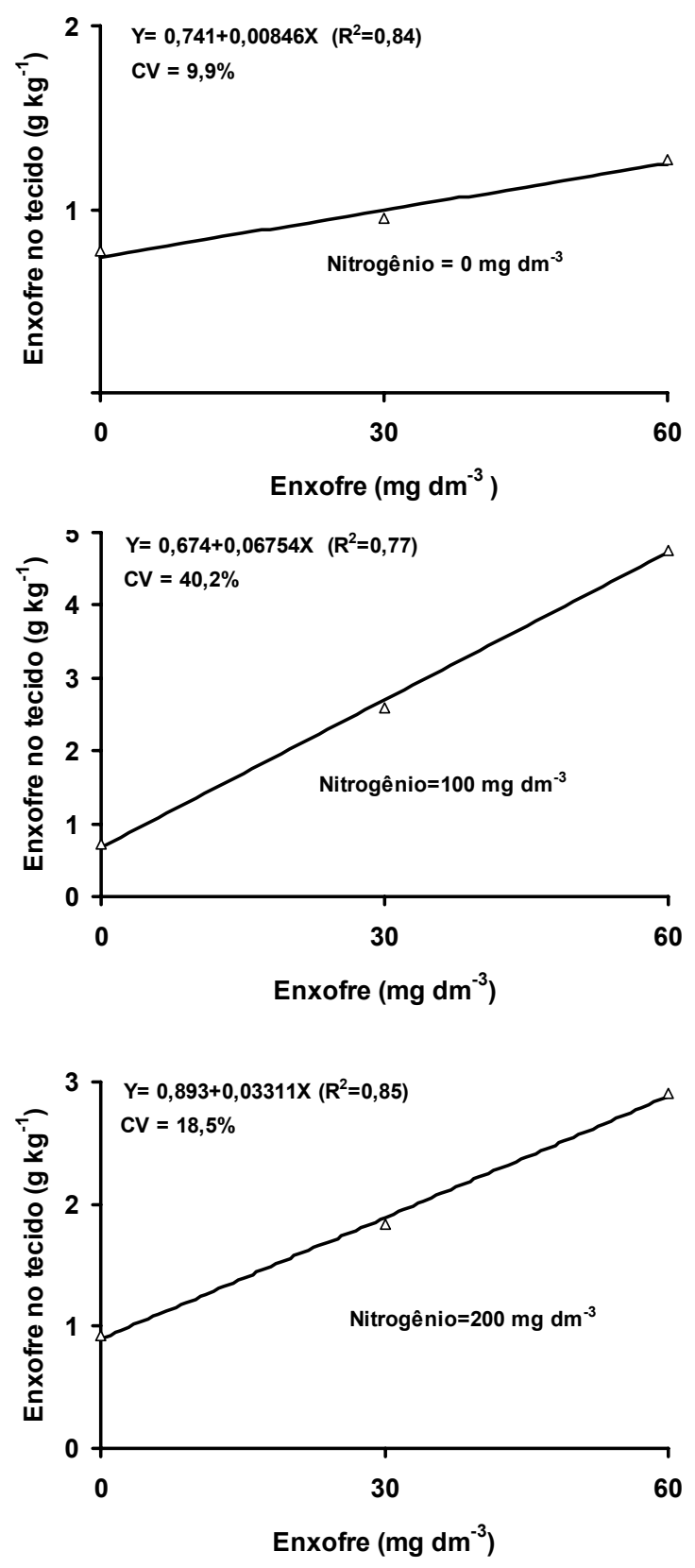

Figura 47 - Concentração de enxofre nas lâminas de folhas recém-expandida da Brachiaria decumbens, no segundo crescimento, em função das doses de enxofre dentro das doses de nitrogênio aplicadas no cilindro proveniente da área recentemente adubada. 
Ferragine \& Monteiro (1999) obtiveram para lâminas de folhas recémexpandidas coletadas nos dois cortes do capim-braquiária submetido a doses de nitrogênio e potássio, modelos quadráticos de regressão. Abreu \& Monteiro (1999) verificaram que as doses de nitrogênio fizeram variar significativamente a concentração de nitrogênio nas lâminas de folhas recém-expandidas.

Cultivando o Panicum maximum cv. Vencedor, Santos et al. (1995) observaram que o teor de nitrogênio aumentou linerarmente nas partes da planta, mediante doses de nitrogênio, tendo as mais altas concentrações ocorrido nas lâminas de folhas recém-expandidas.

Nas lâminas de folhas recém-expandidas coletadas ao final do terceiro crescimento do capim a concentração de nitrogênio ajustou-se a modelo quadrático de regressão. Utilizando-se a equação de regressão pode-se obter nas lâminas de folhas recém-expandidas, a dose de nitrogênio de $130 \mathrm{mg} \mathrm{dm}^{-3}$ que proporciona a máxima concentração de nitrogênio de $36 \mathrm{~g} \mathrm{~kg}^{-1}$ (Figura 48).

A análise de variância revelou que houve significância $(P<0,01)$ das doses de enxofre na concentração de enxofre nas lâminas de folhas recémexpandidas. Os resultados apresentados na Figura 49 demonstram ajuste a um modelo de segundo grau e permitem verificar que a máxima concentração de enxofre nesse componente da forrageira ocorreu na dose de enxofre de $47 \mathrm{mg}$ $\mathrm{dm}^{-3}$. 


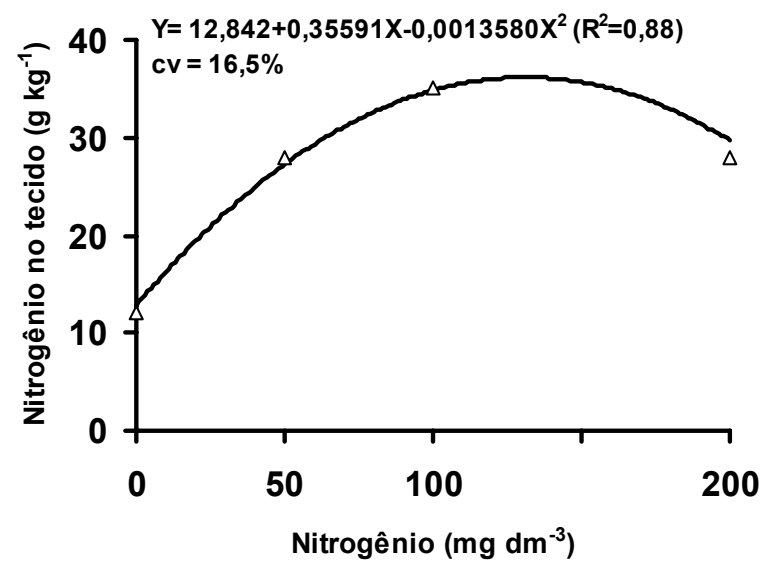

Figura 48 - Concentração de nitrogênio nas lâminas de folhas recém-expandida da Brachiaria decumbens, no terceiro crescimento, em função das doses de nitrogênio aplicadas no cilindro proveniente da área recentemente adubada.

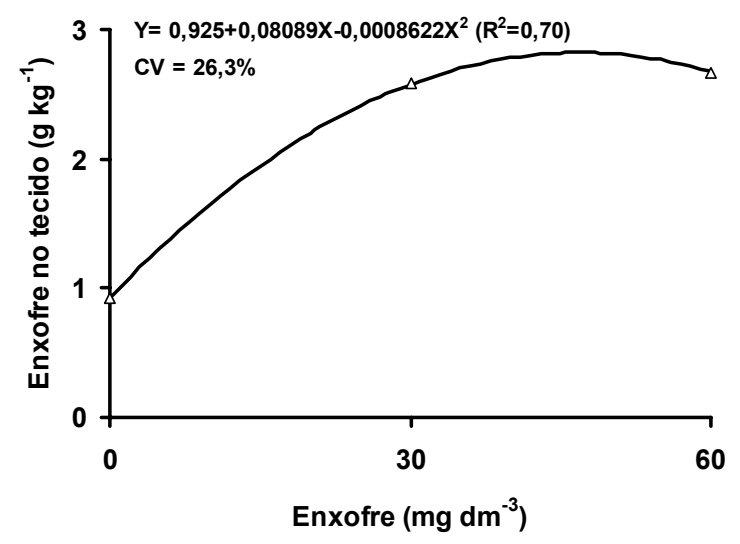

Figura 49 - Concentração de enxofre nas lâminas de folhas recém-expandida da Brachiaria decumbens, no terceiro crescimento, em função das doses de enxofre aplicadas no cilindro proveniente da área recentemente adubada. 


\section{CONCLUSÕES}

- O solo amostrado na área recentemente adubada apresentou teores mais elevados de matéria orgânica, boro, cobre, ferro e zinco nas camadas de 0 a $10 \mathrm{~cm}$ e de 10 a $20 \mathrm{~cm}$, que aquele da área não recentemente adubada;

- O capim-braquiária na pastagem da área recentemente adubada apresentou concentrações mais elevadas de nitrogênio, cobre, ferro e zinco que o capim da área não recentemente adubada;

- O teor de clorofila do capim-braquiária da área recentemente adubada foi superior ao daquele da área não recentemente adubada e apresentou alta correlação com a concentração de nitrogênio nas lâminas foliares;

- Doses de nitrogênio e de enxofre interagem significativamente para o crescimento do capim-braquiária, mas não em termos de número total de perfilhos da forrageira;

- As doses de nitrogênio alteraram a concentração de nitrogênio na folha diagnóstica, no primeiro crescimento, do capim-braquiária; 
- A interação entre as doses de nitrogênio e de enxofre foi significativa para o valor SPAD, no primeiro e no segundo crescimentos, do capim-braquiária;

- Com o incremento no fornecimento de nitrogênio há também necessidade de suprir enxofre para maximizar as respostas do capim-braquiária;

- A aplicação conjunta de doses de nitrogênio e de enxofre de $190 \mathrm{mg} \mathrm{dm}^{-3} \mathrm{e}$ $30 \mathrm{mg} \mathrm{dm}^{-3}$, respectivamente, propiciaram o máximo desenvolvimento do capim-braquiária nas áreas em estudo. 


\section{REFERÊNCIAS BIBLIOGRÁFICAS}

ABREU, J.B.R. Níveis de nitrogênio e proporções de nitrato e amônio afetando produção, atividade da redutase do nitrato e composição de três gramíneas forrageiras. Piracicaba, 1994. 100p. Dissertação (Mestrado) - Escola Superior de Agricultura "Luiz de Queiroz", Universidade de São Paulo.

ABREU, J.B.R.; MONTEIRO, F.A. Produção e nutrição do capim-Marandu em função de adubação nitrogenada e estádios de crescimento. Boletim de Indústria Animal, v.56, n.2, p.137-146, 1999.

ALVIM, M.J.; BOTREL, M.A.; VERNEQUE, R.S. et al. Aplicação de nitrogênio em acessos de Brachiaria. 1. Efeito sobre a produção de matéria seca. Pasturas Tropicales, v.12, n.2, p.2-6, 1990.

ARRUDA, N.G. de; CANTARUTTI, R.B.; MOREIRA, R. de. Tratamentos físicomecânico e fertilização na recuperação de pastagens de Brachiaria decumbens em solos de tabuleiro. Pasturas Tropicales, v.9, p.36-39, 1987. 
BODDEY, R.M.; RESENDE, C.P.; SCHUNKE, R.M. et al. Sustentabilidade de pastagens consorciadas e de gramínea em monocultura; o papel chave das transformações de nitrogênio. In: SIMPÓSIO SOBRE: O MEIO AMBIENTE, OS RECURSOS NATURAIS E A PRODUÇÃO ANIMAL. 1993, Anais. 1993, p. 76-99.

BOORNMAN, J.G. Experimental studies on seed production of tropical grasses in Kenya. 5. The effect of time of nitrogen top dressing on seed crops of Setaria sphacelata cv. Nandi. Netherlands Journal of Agricultural Science, v. 20, p. 225-231, 1971.

BREDON, R.N.; HORREL, C.R. The chemical composition and nutritive value of some common grasses in Uganda - II. The comparison of chemical composition and nutritive value of grasses throughout the year, with special reference to the later stage of growth. Tropical Agriculture, v. 39, n.1, p. 13-17, 1962.

CARVALHO, M.M.; MARTINS, C.E.; VERNEQUE, R.S. et al. Respostas de uma espécie de Brachiaria à fertilização com nitrogênio e potássio em um solo ácido. Revista Brasileira de Ciência do Solo, v.15, n.2, p.195-200, 1991.

CARVALHO, S.I.C.; VILELA, L.; SPAIN, J.M. et al. Recuperação de pastagens degradadas de Brachiaria decumbens cv. Basilisk na região dos cerrados. Pasturas Tropicales, v.12, p.24-28, 1990.

CASAGRANDE, J.C.; SOUZA, O.L. Efeito de níveis de enxofre sobre quatro gramíneas forrageiras tropicais em solos sob vegetação de cerrado do Mato Grosso do Sul, Brasil. Pesquisa Agropecuária Brasileira, v.17, n.1, p.21-25, 1982. 
COLOZZA, M.T. Rendimento e diagnose foliar dos capins Aruana e Mombaça cultivados em latossolo vermelho-amarelo adubado com doses de nitrogênio. Piracicaba, 1998. 126p. Tese (Doutorado) - Escola Superior de Agricultura "Luiz de Queiroz", Universidade de São Paulo.

CORREAA, B.D. Doses de nitrogênio e de magnésio afetando aspectos produtivos e bioquímicos dos capins Colonião, Tanzânia-1 e Vencedor. Piracicaba, 1996. 76p. Dissertação (Mestrado) - Escola Superior de Agricultura "Luiz de Queiroz", Universidade de São Paulo.

CORSI, M. Pastagens de alta produtividade. In: SIMPÓSIO SOBRE MANEJO DE PASTAGEM, 8., Piracicaba, 1986. Anais. Piracicaba: FEALQ, 1986. p. $1-14$.

FAQUIN, V.; CURI, N.; MARQUES, J.J.G.S.M. et al. Limitações nutricionais para gramíneas forrageiras em Cambissolo álico da microregião Campos da Mantiqueira-MG, Brasil. 2. Nutrição em macro e micronutrientes. Pasturas Tropicales, v.17, n.3, p.17-22, 1995a.

FAQUIN, V.; HOFFMANN, C.R.; EVANGELISTA, A.R. et al. O potássio e o enxofre no crescimento da braquiária e do colonião em amostras de um Latossolo da região noroeste do Paraná. Revista Brasileira de Ciência do Solo, v.19, n.1, p.87-94, 1995b.

FERNANDES, F.M.; ISEPON, O.J.; NASCIMENTO, V.M. Resposta de Brachiaria decumbens Stapf. a níveis de N, P e K em solo originalmente coberto por vegetação de cerrado. Científica, v.13, n.1/2, p.89-97,1985. 
FERRAGINE, M. del C.; MONTEIRO, F.A. Combinação de doses de nitrogênio e potássio na nutrição mineral de capim-braquiária. Boletim de Indústria Animal, v.56, n.1, p.25-33, 1999.

FERRARI JÚNIOR, E.; ANDRADE, J.B. de; PEDREIRA, J.V.S. et al. Produção de feno de Brachiaria decumbens e Brachiaria brizantha cv. Marandu sob três freqüências de corte. I. Produção de matéria seca. Boletim de Indústria Animal, v.51, n.1, p.49-54, 1994.

FERRARI NETO, J. Limitações nutricionais para o colonião (Panicum maximum Jacq.) e (Brachiaria decumbens Stapf.) em latossolo da região noroeste do Estado do Paraná. Lavras, 1991. 126p. Dissertação (Mestrado) - Escola Superior de Agricultura de Lavras.

GALLO, J.R.; HIROCE, R.; BATAGLIA, O.C. et al. Composição química inorgânica de forrageiras do Estado de São Paulo. Boletim de Indústria Animal, v.31, n.1, p.115-137, 1974.

GASTAL, F.; BELANGER, G.; LEMAIRE, G. A model of leaf extension rate of tall fescue in response to nitrogen and temperature. Annals of Botany, v.70, p.437-442, 1992.

GASTAL, F.; LEMAIRE, G. Study of a tall fescue sward under nitrogen deficiency conditions. In: GENERAL MEETING OF THE EUROPEAN GRASSLAND FEDERATION, 12., Dublin, 1988. Proceedings. Dublin, 1988, p. 323-327.

GASTAL, F.; NELSON, C.J. Nitrogen use withing the growing leaf blade of tall fescue. Plant Physiology, v. 105, n.1, p. 191-197, 1994. 
GOMIDE, J.A. Fisiologia do crescimento livre de planta forrageira. Pastagem: Fundamento da exploração racional., Piracicaba: FEALQ, 1986, p.1-10.

HADDAD, C.M. Efeito do enxofre, aplicado na forma de gesso, sobre a produção e qualidade do capim Colonião (Panicum maximum, Jacq.). Piracicaba, 1983. 115p. Tese (Doutorado) - Escola Superior de Agricultura "Luiz de Queiroz", Universidade de São Paulo.

HARDING, W.A.T.; GROF, B. Effect of fertilizer nitrogen on yield, nitrogen content and animal productivity of Brachiaria decumbens cv. Basilisk on the wet tropical coast of North Queensland. Queensland Journal of Agriculture and Animal Sciences, v.35, n.1, p.11-21, 1978.

HOFFMANN, C.R. Nutrição mineral e crescimento de Brachiaria e do Colonião, sob influência das aplicações de nitrogênio, fósforo, potássio e enxofre em Latossolo da região noroeste do Paraná. Lavras, 1992. 204p. Dissertação (Mestrado) - Escola Superior de Agricultura de Lavras.

LOCH, D.S. Tiller development in relation to seed production of tropical grasses. In: INTERNATIONAL GRASSLAND CONGRESS, 15., 1985. Proceedings. 1985, p. $264-266$

LOCH, D.S.; HARVEY, G.L. Preliminary investigation of adhesive sprays to improve seed retention in tropical grasses. Journal of Applied Seed Production, v. 1, p. 26-29, 1983. 
LOURENÇO, A.J. Produção animal com leguminosas arbóreas/arbustivas. In: SIMPÓSIO SOBRE USOS MÚLTIPLOS DE LEGUMINOSAS ARBÓREAS E ARBUSTIVAS, 1., Nova Odessa, 1993. Anais. Nova Odessa: Instituto de Zootecnia, 1993. p.131-146.

MALAVOLTA, E.; HAAG, H.P.; MELLO, F.A.F. et al. Nutrição mineral e adubação de plantas cultivadas. São Paulo: Pioneira, 1974. 727p.

MANARIN, C.A. Respostas fisiológicas, bioquímicas e produtivas do capimMombaça a doses de nitrogênio, 2000. 58p. Dissertação (Mestrado) Escola Superior de Agricultura "Luiz de Queiroz", Universidade de São Paulo.

MATTOS, W.T. Diagnose nutricional de potássio em duas espécies de braquiária. Piracicaba, 1997. 74p. Dissertação (Mestrado) - Escola Superior de Agricultura "Luiz de Queiroz", Universidade de São Paulo.

MAZZANTI, A.; LEMAIRE, G. Effect of nitrogen fertilization on the herbage production of tall fescue swards grazed continuously with sheep. 2 . Comsumption and efficiency of herbage utilisation. Grass and Forage Science, v. 49, n.2, p. 352-359, 1994.

MINOLTA CAMERA. Manual for chlorophyll meter SPAD-502. Osaka, 1989. 22p.

MONTEIRO, F.A.; CARRIEL, J.M. Aplicação de níveis de enxofre na forma de gesso para cultivo do capim-colonião em dois solos arenosos do Estado de São Paulo. Boletim de Indústria Animal, v.44, n.2, p.335-347, 1987. 
MONTEIRO, F.A.; ONO, M.N. Níveis de enxofre em Brachiaria brizantha cv. Marandu cultivada em solução nutritiva. In: CONGRESSO BRASILEIRO DE CIÊNCIA DO SOLO, 25., Viçosa, 1995. Resumos. Viçosa: SBCS;UFV, 1995. p.1021-1022.

MONTEIRO, F.A.; WERNER, J.C. Ciclagem de nutrientes minerais em pastagens. In: SIMPÓSIO SOBRE ECOSSISTEMA DE PASTAGENS, 1., Jaboticabal, 1989. Anais. Jaboticabal: FUNEP, 1989. p.149-192.

MONTEIRO, F.A.; MATTOS, W.T.; MARTIM, R.A. Partes das plantas e diagnose nutricional de fósforo em Braquiária decumbens, In: CONGRESSO BRASILEIRO DE CIÊNCIA DO SOLO, 25., Viçosa,1995. Resumos. Viçosa: SBCS;UFV;DPS, 1995. p. 556-557.

NABINGER, C.; MEDEIROS, R.B. de Produção de sementes de Panicum maximum Jacq. In: SIMPÓSIO SOBRE MANEJO DA PASTAGEM, 12, Piracicaba, 1995. Anais. Piracicaba: FEALQ, 1995. p. 59-128.

NABINGER, C.;MEDEIROS, R.B. de Eficiência do uso de pastagens: disponibilidade e perdas de forragem. In: SIMPÓSIO SOBRE MANEJO DA PASTAGEM, 14., Piracicaba, 1997. Anais. Piracicaba: FEALQ, 1997. p. 213-251.

NASCIMENTO Jr., D. Ecossistema de pastagens cultivadas. In: SIMPÓSIO SOBRE MANEJO DA PASTAGENS, 15., Piracicaba, 1998. Anais. Piracicaba: FEALQ, 1998. p. 271-296. 
OLIVEIRA, M.A. de. Estudo de crescimento e valor nutritivo do capim brachiaria (Brachiaria decumbens Stapf.). Piracicaba, 1980. 88p. Dissertação (Mestrado) - Escola Superior de Agricultura "Luiz de Queiroz", Universidade de São Paulo.

PEREIRA, J.P. Adubação de capins do gênero Brachiaria. In: ENCONTRO PARA DISCUSSÃO DOS CAPINS DO GÊNERO BRACHIARIA, Nova Odessa,1986. Anais. Nova Odessa: Instituto de Zootecnia, 1986. p.117196.

PINTO, J.C.; GOMIDE, J.A.; MAESTRI, M. et al. Crescimento de folhas de gramíneas forrageiras tropicais, cultivadas em vasos, com duas doses de nitrogênio. Revista da Sociedade Brasileira de Zootecnia, v. 23, p. 327332, 1994.

RAIJ, B. van Fertilidade do solo e adubação. São Paulo: Ceres: Associação Brasileira para Pesquisa da Potassa e do Fosfato, 1991. 343p.

RAIJ, B. van; QUAGGIO, J. A. Métodos de análise de solo para fins de fertilidade. Campinas: Instituto Agronômico, 1983. 31p. (IAC. Boletim Técnico, 81).

RAIJ, B. van; CANTARELLA, H.; QUAGGIO, J.A. et al. Recomendações de adubação e calagem para o Estado de São Paulo. Campinas: Instituto Agronômico, 1986. 285p. (IAC. Boletim Técnico, 100). 
SALINAS, J.G.; GUALDRÓN, R. Adaptación y requiremento de fertilización de Brachiaria humidicola (Rendle) Schweikt en la altillanura plana de los Llanos Orientales de Colombia. In: SIMPÓSIO SOBRE O CERRADO. 6., Brasília, 1982. Anais. Planaltina: EMBRAPA, CPAC, 1988. p.457-471.

SANTOS, A. R. Diagnose nutricional e respostas do capim-braquiária submetido a doses de nitrogênio e enxofre. Piracicaba, 1997. 115p. Tese (Doutorado). Escola Superior de Agricultura "Luiz de Queiroz", Universidade de São Paulo.

SANTOS, A.R.; CORREAA, B.D.; MONTEIRO, F.A. Efeitos de níveis de nitrogênio sobre o rendimento de matéria seca, teor de nitrogênio e perfilhamento em Panicum maximum cultivar Vencedor. In: CONGRESSO BRASILEIRO DE CIÊNCIA DO SOLO, 25, Viçosa, 1995. Resumos. Viçosa: SBCS; UFV, 1995. p.741-742.

SANZONOWICZ, C. Recomendação e prática de adubação e calagem na região centro-oeste do Brasil. In: SIMPÓSIO SOBRE CALAGEM E ADUBAÇÃO DE PASTAGENS. 1., Nova Odessa, 1985. Anais. Piracicaba: Associação Brasileira para a Pesquisa da Potassa e do Fosfato, 1986. p.309-336.

SARRUGE, J. R.; HAAG, H. P. Análises químicas em plantas. Piracicaba: ESALQ, Departamento de Química, 1974. 54p.

SAS INSTITUTE CORPORATION. Propriety software release 6.08. Cary, 1989. 
SIQUEIRA, O.J.F.; SHERER, E.E.; TASSINARI, G. et al. Recomendações de adubação e calagem para os estados do Rio Grande do Sul e de Santa Catarina. Passo Fundo: EMBRAPA, CNPT, 1987. 100p.

SOARES FILHO, C.V. Tratamentos físico-mecânico, correção e adubação para recuperação de pastagens In: ENCONTRO SOBRE RECUPERAÇÃO DE PASTAGENS. 1., Nova Odessa, 1993. Anais. Nova Odessa: Instituto de Zootecnia, 1993. p.79-117.

SOARES FILHO, C. V. ; MONTEIRO, F. A. ; CORSI, M. Recuperação de pastagens degradadas de Brachiaria decumbens. 1. Efeito de diferentes tratamentos de fertilização e manejo. Pasturas Tropicales, v.14, n.2, p.1-6, 1992.

TAMASSIA, L.F.M.; MONTEIRO, F.A.; MANARIN, C.A. et al. Interação entre doses de nitrogênio e de enxofre para o estabelecimento e perfilhamento do capim Tanzânia. In: REUNIÃO ANUAL DA SOCIEDADE BRASILEIRA DE ZOOTECNIA, 36. Porto Alegre, 1999. Anais... Porto Alegre:SBZ, 1999, CDROM

TAIZ, L.; ZEIGER, E. Plant physiology. Redwood City: The Benjamin/Cumminggs, 1991. cap. 12, p. 292-317.

VICENTE-CHANDLER, J. Intensive grassland management in Puerto Rico. Revista da Sociedade Brasileira de Zootecnia, v.2, n.1, p.173-215, 1973.

VICENTE-CHANDLER, J.; SILVA, S.; ABRUNÃ, F. et al. Effect of two cutting heights, four harvest intervals and five nitrogen rates on yield and composition of Congo Grass under humic tropical conditions. Journal of Agriculture of University of Puerto Rico, v.56, n.3, p.280-291, 1972. 
VITTI, G.C.; NOVAES, N.J. Adubação com enxofre. In: SIMPÓSIO SOBRE CALAGEM E ADUBAÇÃO DE PASTAGENS, 1., Nova Odessa, 1985. Anais. Piracicaba: Associação Brasileira de Pesquisa da Potassa e do Fosfato, 1986. p.191-231.

VOLENEC, J.J.; NELSON, C.J. Responses of tall fescue leaf meristems to $\mathrm{N}$ fertilization and harvest frequency. Crop Science, v.23, p.720-724, 1983.

WERNER, J.C. Adubação de pastagens. Nova Odessa: Instituto de Zootecnia, 1986. 49p. (IZ. Boletim Técnico, 18).

WERNER, J.C.; MONTEIRO, F.A. Respostas das pastagens à aplicação de enxofre. In: SIMPÓSIO: ENXOFRE E MICRONUTRIENTES NA AGRICULTURA BRASILEIRA, Londrina, 1988. Anais. Londrina: EMBRAPA, CNPS; IAPAR, 1988. p.87-102.

WILMAN, D.; DROUSHIOTIS, D.; MZAMANE, M.N. et al. The effect of interval between harvests and nitrogen application on initiation, emergence and longevity of leaves, longevity of tillers and dimensions and weights of leaves and "stems" in Lolium. Journal Agriculture of Science, v.89, n.1, p.65-79, 1977. 